\title{
AVALIAÇÃO DA EFICÁCIA DOS MÉTODOS DE INSTRUMENTAÇÃO E DE SUBSTÂNCIAS QUÍMICAS NAS PAREDES DE CANAIS RADICULARES. \\ - ESTUDO EM MICROSCOPIA ELETRÔNICA DE VARREDURA -
}

\section{ROGÉRIO EMÍLIO DE SOUZA}

Tese apresentada à Faculdade de Odontologia de Bauru, da Universidade de São Paulo, como parte dos requisitos para obtenção do título de Doutor em Odontologia, área de Endodontia.

(Edição Revisada) 


\title{
AVALIAÇÃO DA EFICÁCIA DOS MÉTODOS DE INSTRUMENTAÇÃO E DE SUBSTÂNCIAS QUÍMICAS NAS PAREDES DE CANAIS RADICULARES. - ESTUDO EM MICROSCOPIA ELETRÔNICA DE VARREDURA -
}

\section{ROGÉRIO EMÍLIO DE SOUZA}

\begin{abstract}
Tese apresentada à Faculdade de Odontologia de Bauru, da Universidade de São Paulo, como parte dos requisitos para obtenção do título de Doutor em Odontologia, área de Endodontia.
\end{abstract}

(Edição Revisada)

Orientador: Prof. Dr. Norberti Bernardineli 


\begin{tabular}{|l} 
So89a Souza, Rogério Emílio de \\
Avaliação da eficácia dos métodos de instrumentação e \\
de substâncias químicas nas paredes de canais \\
radiculares - Estudo em microscopia eletrônica de \\
varredura / Rogério Emílio de Souza. -- Bauru, 2005. \\
xx, 109p. : il ; $30 \mathrm{~cm}$. \\
Tese (Doutorado) -- Faculdade de Odontologia de \\
Bauru. Universidade de São Paulo. \\
Orientador: Prof. Dr. Norberti Bernardineli
\end{tabular}

Data de aprovação pelo comitê de Ética em pesquisa da FOB: 28 de abril de 2004. $\mathrm{N}^{0}$ do protocolo: $41 / 2004$

Autorizo, exclusivamente para fins acadêmicos e científicos, a reprodução total ou parcial desta tese, por processos fotocopiadores e outros meios eletrônicos.

Assinatura do autor:

Data: 


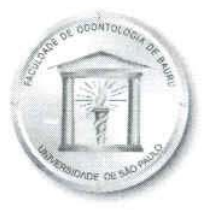

Universidade de São Paulo

\section{Faculdade de Odontologia de Bauru}

Al. Dr. Octávio Pinheiro Brisolla, 9-75 - Bauru-SP - CEP 17012-101 - C.P. 73

PABX (OXX14)235-8000 - FAX (0XX14)223-4679

Pos-Graduafão

e-mail: posgrad@fob.usp.br -Fone: (0XX14)235-8223

\section{FOLHA DE APROVAÇÃO}

Tese apresentada e defendida por ROGÉRIO EMÍLIO DE SOUZA

e aprovada pela Comissão Julgadora

em 30 de setembro de 2005.

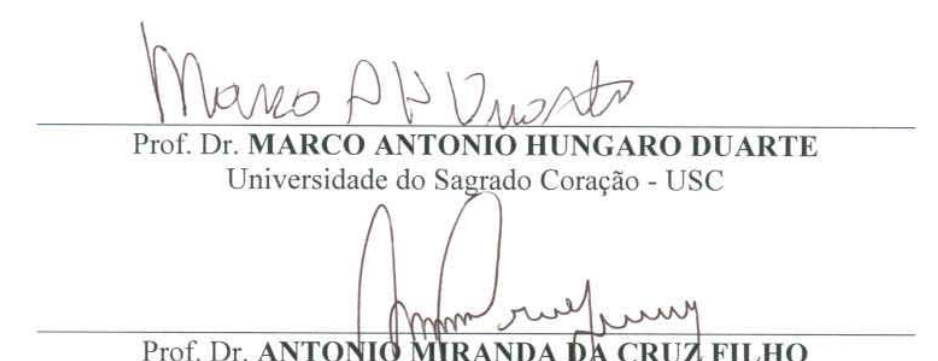

Prof. Dr. ANTONIO MIRANDA DA CRUZ FILHO

Faculdade de Odontologia -Universidade de Ribeirão Preto
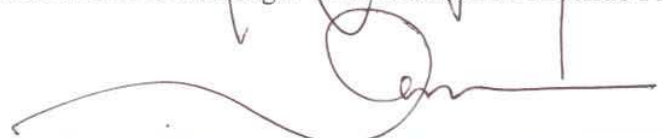

Prof. ${ }^{a}$ Dr. ${ }^{a}$ MARIA APARECIDA DE ANDRADE MOREIRA MACHADO

Faculdade de Odontologia de Bauru - USP

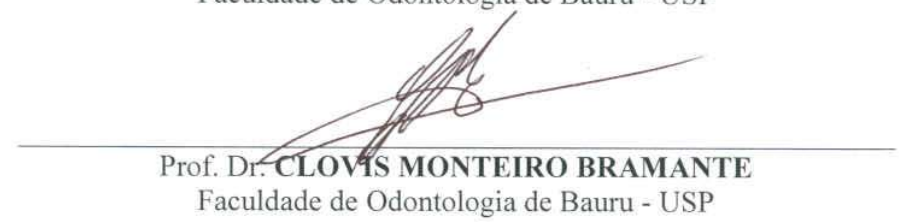

Faculdade de Odontologia de Bauru - USP
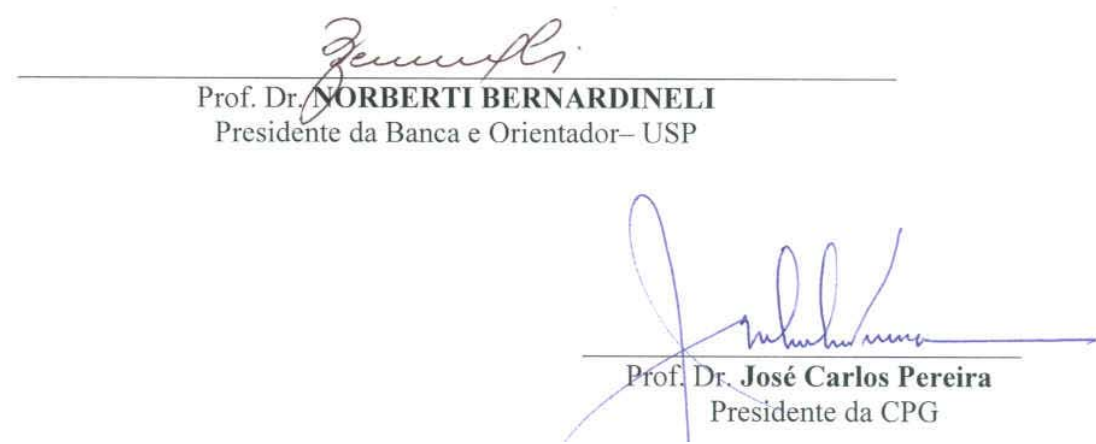
"É um privilégio trabalhar com os jovens, mas também um risco.

Se é difícil ser pai, muito mais ser a síntese de muitos pais dentro de uma sala de aula.

Ser professor não é transmitir conhecimentos frios e descarnados.

É influir na vida.

É motivar.

É ter não apenas alunos, mas discípulos, seguidores.

O homem de hoje é cada vez mais terreno e horizontal.

Exige, pois, que o professor seja cada vez mais educador, aquele que ergue as pessoas, que as torna verticais.

Educar homens é mais importante que explorar a lua.

É ajudar o jovem a se desenvolver, a confiar a participar.

É um ato de fé,

de amor,

de compreensão.

O mundo necessita mais de bondade e carinho que de frações e logaritmos".

(Palavras de Santo Antônio proferidas por minha mãe) 


\section{ROGÉRIO EMÍLIO DE SOUZA}

Nascimento

Filiação

$1992-1995$

$2001-2002$

$2001-2003$

$2003-2004$

$2004-2005$

2005 - atual

$2003-2005$

Associações
13 de julho de 1973, Ilha Solteira/SP

Benedito de Souza e Maria Benedita de Souza

Curso de Odontologia - Universidade do Estado de

São Paulo-UNESP-“Júlio de Mesquita Filho"

Campus de Araçatuba/SP

Curso de Pós-Graduação em Endodontia em nível de Mestrado na Universidade de Ribeirão Preto.

Professor do curso de Odontologia, disciplina de Endodontia da Universidade Federal do ParanáPR/UFPR.

Professor do curso de Odontologia, disciplina de Endodontia da Universidade de Rio PretoSP/UNIRP.

Professor do curso de Odontologia, disciplina de Endodontia da Faculdade de Imperatriz-MA/FACIMP Responsável pelo departamento científico da Associação Brasileira de Odontologia, Imperatriz/MA.

Curso de Pós-Graduação em Endodontia em nível de Doutorado na Faculdade de Odontologia de Bauru-SP/USP

ABO/MA - Associação Brasileira de Odontologia.

SBPqO - Sociedade Brasileira de Pesquisa Odontológica.

APCD - Associação Paulista de Cirurgiões Dentistas. 


\section{Dedicatórias}




\section{Ao Senhor meu Deus:}

Pela vida, pelos dons que me deste, Pela paz de minha alma, pela fé.

O amor e a esperança.

Pela benção radiosa que recebo todas as manhãs de alegria.

Pelo meu lar, minha família e meus amigos,

Pelo abrigo, pelo pão de cada dia que me dá força e sustento para continuar minha caminhada.

Senhor, eu te louvo pela grande alegria que me traz e ter sempre a certeza de tua presença ao meu lado.

${ }^{10}$ Deus ordenará aos seus anjos a teu respeito, que te guardem com cuidado'. ${ }^{11} \mathrm{E}$ mais ainda: 'Eles te levarão nas mãos, para que não tropeces em nenhuma pedra'

(Lucas 4,10-11)

\section{A minha avó Edna Mesquita Ribeiro:}

Duplamente mãe e infinitamente amável comigo e meus defeitos.

${ }^{10}$ Os meus conselhos multiplicarão os anos de sua vida. ${ }^{11}$ Estou the mostrando o caminho da sabedoria e guiando você pelas trilhas da retidão. ${ }^{12}$ Ao caminhar, seus passos não vão se embaraçar e, ao correr, você não tropeçará. ${ }^{13}$ Agarre-se à disciplina, e não a solte; pratique a disciplina, porque ela é a sua vida.

(Provérbios 4,10-13)

\section{Ao meu pai, Benedito de Souza e}

minha mãe, Maria Benedita de Souza:

Pelo amor sem limite, pela paciência e educação que me permitem alcançar mais e mais conquistas com humildade e respeito ao próximo.

${ }^{20}$ Meu filho, guarde os preceitos de seu pai e não despreze o ensinamento de sua mãe. ${ }^{21}$ Conserve-os sempre vivos na memória e amarre-os no pescoço. ${ }^{22}$ Desse modo, quando você caminhar, eles o guiarão; quando você descansar, eles o guardarão; e quando você despertar, eles falarão com você. ${ }^{23}$ Porque o preceito é uma lâmpada, a instrução é uma luz e a repreensão que corrige é caminho de vida.

(Provérbios 6,20-23)

\section{A minha tia "mãe" Eliana Elizabeth Ribeiro}

e minha amada cunhada Marta Graziela Manilha de Souza:

Mulheres de valor que superaram e superam obstáculos mostrando caminhos dantes impossíveis.

Senhor.

${ }^{14}$ Casa e riquezas são herdadas dos pais, mas a mulher prudente vem do

(Provérbios 19, 14) 


\section{A minha amada e sempre companheira Juliane Guimarães Tebar :}

Exemplo de humildade e simplicidade, suas atitudes, delicadas e sutis, refletem paz e transparência. Sua admiração e respeito são pilares para suportar as mais distintas situações, respeitando sempre o desejo Divino. Em curto espaço, físico de tempo, mostrou-se um porto seguro. Companheira que, no momento exato, entrou e permanece em minha vida sempre prestativa e de bom coração soube lidar com minha ausência para que este "fruto" fosse colhido maduro. Estou em paz com você, Amor.

${ }^{1}$ Toda mulher sábia edifica a sua casa.

(Provérbios 14, 1)

${ }^{21}$ Então, o Senhor Deus fez cair pesado sono sobre o homem, e este adormeceu, tomou uma das suas costelas e fechou o lugar com carne. ${ }^{22} \mathrm{E}$ a costela que o Senhor Deus tomara ao homem transformaram-a numa mulher e lhe trouxe. ${ }^{23} \mathrm{E}$ disse o homem: Esta, afinal, é osso dos meus ossos e carne da minha carne, chamar-se-á mulher, porquanto do homem foi tomada. ${ }^{24}$ Por isso, deixa o homem pai e mãe e se une à sua mulher, tornando-se os dois um só carne.

(Gênesis 2, 21-24)

Aos meus irmãos: Eduardo Antônio de Souza,

Fernando Wilson de Souza e Rafael Francisco de Souza:

\section{Pelo eterno amor e companheirismo.}

${ }^{9}$ Mais vale estar a dois do que estar sozinho, porque dois tirarão maior proveito do seu trabalho. ${ }^{10}$ De fato, se um cai, poderá ser levantado pelo companheiro. Azar, porém, de quem está sozinho: se cair, não terá ninguém para o levantar. ${ }^{11}$ Se dois se deitam juntos, um poderá aquecer o outro; mas como poderá alguém sozinho se aquecer? ${ }^{12} \mathrm{Se}$ um deles for agredido, dois poderão resistir, e uma corda tripla não se arrebenta facilmente.

(Eclesiastes 4, 9-12)

Ao meu amado sobrinho e afilhado Murilo Manilha de Souza:

Criança que trouxe a paz e ascendeu o amor, antes latente, em minha vida. Criança que transmite luz nos passos iluminando o seu e o nosso caminho, dotado de alegria e irreverência. Mostra simplicidade nos gestos e vigor nas atitudes. Revela que sonhos são investimentos em nossa personalidade. E são ilimitados.

${ }^{8}$ Havia também no mesmo país pastores vivendo ao ar livre e mantendo de noite vigílias sobre os seus rebanhos. ${ }^{9} \mathrm{E}$, repentinamente estava parado ao lado deles o anjo de Deus, e a glória de Deus reluzia em volta deles, e ficaram muito temerosos. ${ }^{10}$ Mas o anjo disse-Ihes: "Não temais, pois, eis que vos declaro boas novas duma grande alegria que todo o povo terá. 


\section{Ao meu sobrinho Gabriel Laraya de Souza:}

Pessoa de caráter valioso que vem modelando-o sob as mais distintas situações vividas mostra-se com resistência e perseverança nos desejos pessoais mais profundos.

${ }^{14}$ Glória a Deus nas maiores alturas e na terra paz entre homens de boa vontade.

(Lucas 2, 14)

\section{Ao amigo Max Amilcar Ehrenberg Dossi:}

Companheiro de todos caminhos e situações. Quando em trilhas tortas nunca deixou de buscar e mostrar-me as retilíneas.

${ }^{14}$ Amigo fiel é proteção poderosa e quem o encontrar terá encontrado um tesouro. ${ }^{15}$ Amigo fiel não tem preço, e o seu valor é incalculável. ${ }^{16}$ Amigo fiel é remédio que cura, e os que temem ao Senhor o encontrarão.

(Eclesiástico 6,14-17)

\section{A família Santi Rodrigues da cidade de Curitiba/PR (Wilson, Mari, Wilson Jr, Willian e Jéssica:}

Família que, pacientemente, me conduz por caminhos de luz.

${ }^{8}$ Sejam sóbrios e fiquem de prontidão! Pois o diabo, que é o inimigo de vocês, os rodeia como um leão que ruge, procurando a quem devorar. ${ }^{9}$ Resistam ao diabo, permanecendo firmes na fé, pois vocês sabem que essa mesma espécie de sofrimento atinge os seus irmãos que estão espalhados pelo mundo. ${ }^{10}$ Depois de sofrerem um pouco, o Deus de toda graça, aquele que os chamou em Cristo para a sua glória eterna, ele os restabelecerá, firmará e fortalecerá, e fará com que vocês sejam inabaláveis. ${ }^{11} \mathrm{~A}$ Deus pertence todo o poder para sempre.

(1 Pedro 5,8-11)

\section{Aos ausentes:}

Parentes e amigos que, materialmente, passaram por mim; no entanto, deixaram suas experiências e ótimas recordações.

${ }^{21}$ Assim como o Pai ressuscita os mortos e lhes dá a vida, o Filho também dá a vida a quem ele quer dar. ${ }^{22} \mathrm{O}$ Pai não julga ninguém. Ele deu ao Filho todo o poder de julgar, ${ }^{23}$ para que todos honrem o Filho, da mesma forma que honram o Pai. Quem não honra o Filho, também não honra o Pai que o enviou. ${ }^{24}$ Eu garanto a vocês: quem ouve a minha palavra e acredita naquele que me enviou, possui a vida eterna. Não será condenado, porque já passou da morte para a vida.

(João 5,21-24) 
Agradecimentos 
Ao meu orientador Prof. Dr. Norberti Bernardineli, pessoa distinta que, mesmo em silêncio, esteve ao meu lado como orientador e amigo. Foi de inestimável valor para a construção e manutenção de meu futuro, não só profissional, como também pessoal. Meu muito obrigado pela confiança em mim depositada quando aceitou orientar-me.

Aos professores da Disciplina de Endodontia da Faculdade de Odontologia de Bauru, Universidade de São Paulo, Prof. Dr. Clóvis Monteiro Bramante, Prof. Dr. Ivaldo Gomes Moraes e Prof. Dr. Roberto Brandão Garcia. Pessoas que estiverem comigo mostrando-me que os caminhos retilíneos nem sempre são acompanhados de paz, harmonia e garantia de chegada.

Ao Prof. Dr. Marco Antônio Húngaro Duarte, pessoa indispensável e de grande valor. Mesmo perante numerosos compromissos e afazeres e, não raro, abdicando dos momentos familiares, sempre se encontrou disposto, com alegria e humildade, a estender a mão amiga e calorosa para concretização dessa jornada. Jamais se mostrou indisposto e jamais esquecerei os resultados de seus gestos.

Ao Prof. Dr. Antônio Miranda da Cruz Filho, pessoa íntegra que jamais deixou de creditar confiança e respeito em minhas atitudes, orientador de meu Mestrado e exemplo de humildade a ser seguido, suas atitudes levam-me a respeitá-lo e admirá-lo.

A equipe da Disciplina de Endodontia da minha amada Faculdade de Odontologia - UNESP - Campus de Araçatuba/SP: Prof. Dr. Roberto Holland, Prof. Dr. Valdir de Souza, Prof. Dr. Pedro Felício Estrada Bernabé, Prof. Dr. Mauro Juvenal Nery, Prof. Dr. José Arlindo Otoboni Filho e Prof. Dr. Elói Dezan Júnior. Guias do ensino e aprendizagem que regaram a semente da busca pela ciência e hoje a colheita faz se abundante. 
Ao Prof. MsC Sérgio Herrero Moraes sempre presente e disposto a estender uma mão amiga. Homem de grande sabedoria nas ações, sua mão ajudou a modelar minha personalidade, não só profissional, alterando para melhor as trajetórias do meu futuro.

Ao incansável Edimauro de Andrade, exemplo de força de vontade, simpatia, alegria e disposição em auxiliar o próximo. Gigante em suas ações, sempre bem humorado, em momento algum mediu limites para estar presente e contribuir com a ciência. Teve participação direta para a continuidade e obtenção desse trabalho de pesquisa.

A equipe que compôs a turma de Doutorado em Endodontia: Everdan Carneiro, Fábio Picoli, Fernanda Gomes de Moraes, Giovana Callicho Canova, Graziela Garrido Mori, Renato Menezes da Silva, Silvana Beltrami Gonçalvez, Ulisses Xavier da Silva Neto e Viviane Haiub Brosco, pelos momentos de auxílio e companheirismo.

As funcionárias da Disciplina de Endodontia Neide Leandro e Patrícia Fernanda Vital Lopes, não se limitaram à relação profissional, foram além. Alcançaram e conquistaram a esfera da amizade. Provaram que a convivência entre pessoas não é formada por camadas hierárquicas segregadas, mas homogêneas.

A secretária da Endodontia Suely Regina Bettio que a sua maneira mostrou sempre presente quando necessária. Obrigado.

A equipe da pós-graduação Giane Tenório Quintela, Maria Margareth Pereira Mokarzel, Ana Letícia Palombo Momesso e Jéferson de Oliveira Melo. Pessoas agradáveis que, mesmo dentro de uma sala distante - fisicamente, executaram os mais dignos feitos para minha pessoa. Fica o carinho, a simpatia e a saudade.

Ao pessoal da biblioteca - FOB/USP: Cybelle de Assumpção Fontes, Maria Helena Sousa Ronchesel, Rita de Cássia Paglione, Vera Regina Casari Boccato, Marcelo Cardoso Freitas Gonçalves, 
Mônica Alves Moreira Bucci, Jane Pimentel Nogueira, Valéria Cristina Trindade Ferraz, Maria Otília Alves Lima, Ademir Padilha, Ana Paula Moço Libel, César Augusto do Amaral Campos, Maria José dos Santos Formenti pessoas que transformaram os momentos sisudos de estudos em descontração.

Ao pessoal do xerox Ana Paula Bertonha, Salvador Cruz Félix e Adriane Lúcia Pereira acompanharam e participaram dessa "maratona" sempre prestativos e alegres.

Ao pessoal da biblioteca - FORP/USP: Izilda Aparecida Pires, Lívia Porto Zocco, Marta Benedita Pereira Conga, Mirian Romano Henrique dos Santos Porto que não se intimidaram perante à distância física, mostrando-se sempre dispostos a estender a mão amiga.

Ao Núcleo de Apoio à Pesquisa em Microscopia Eletrônica Aplicada à Pesquisa Agropecuária (NAP/MEPA) da Escola Superior de Agricultura "Luiz de Queiroz"- ESALQ (Universidade de São Paulo-USP).

A família Bramante (Alexandre, Lucila, Nathalia, Leonardo e Bianca) que me forneceram uma "segunda casa" sem distinção, limites, com muito amor e confiança na cidade de Bauru/SP. A maneira gentil e educada que me receberam foi uma grande base para a finalização dessa obra.

A família Guimarães Tebar da cidade de Imperatriz/MA (Francisco, Creuza, Luciano, Leonardo e Juliane) pessoas abençoadas que não economizaram amor, carinho e compreensão para comigo. Mostraram-me que paciência requer muita prática e que algumas vezes, a pessoa que imaginamos que chutar-te-á quando caímos, será uma das poucas que ajudar-te-á a levantar-se. 
A todos os alunos, presentes e passados, de todos os âmbitos, graduação e pós-graduação, pelo convívio e oportunidade de relacionamento, onde a troca de ensino e aprendizagem, com certeza, foi recíproca.

E, por fim, a todos que direta ou indiretamente participaram e colaboraram para a confecção e conclusão deste projeto que antes era sonho, mas hoje se concretiza em REALIDADE. O que antes era um ponto de chegada se faz hoje um ponto de partida.

Meus mais sinceros AGRADECIMENTOS.

_Obrigado. 


\section{SUMÁRIO}

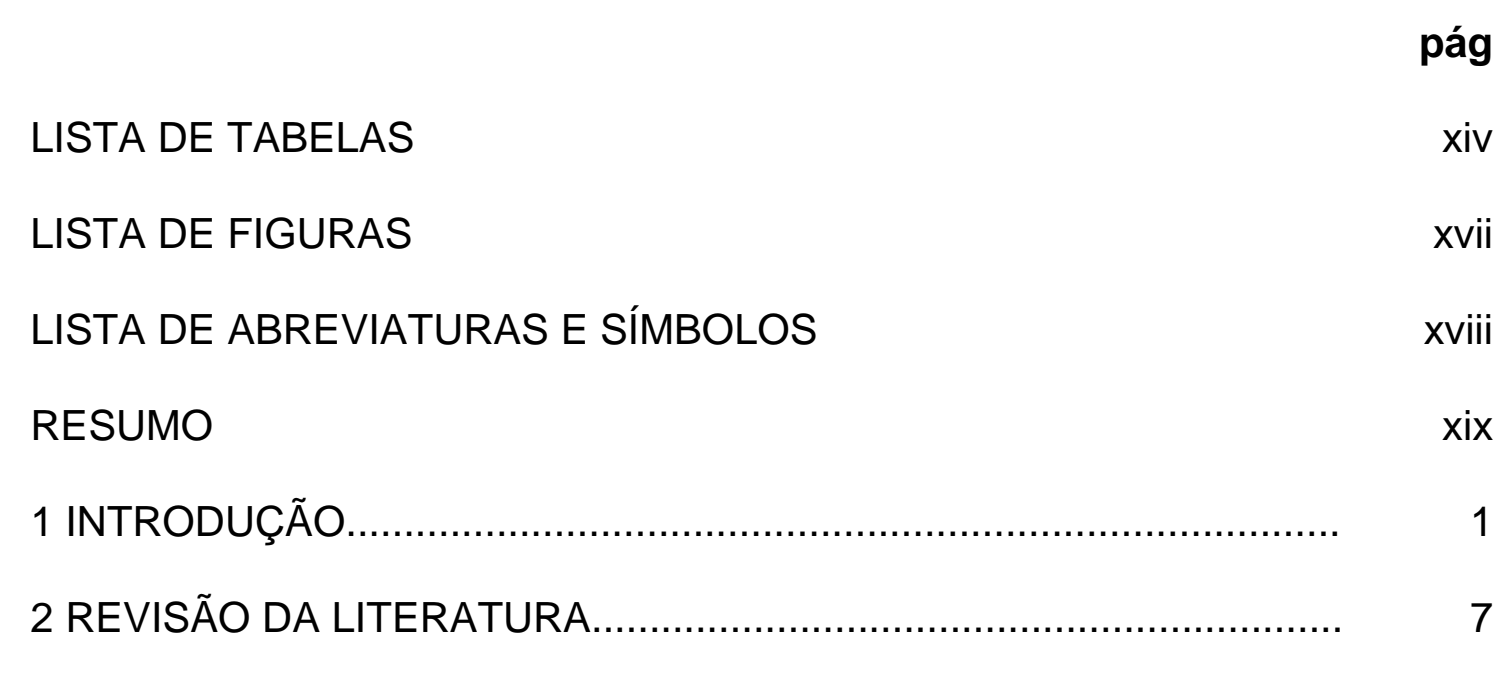

2.1 Substâncias químicas auxiliares da instrumentação................. 8

2.2 Instrumentação do canal radicular - técnicas e métodos............ 21

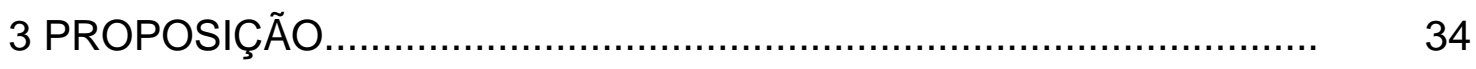

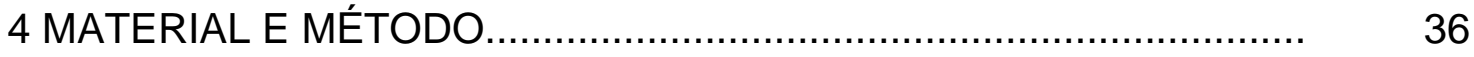

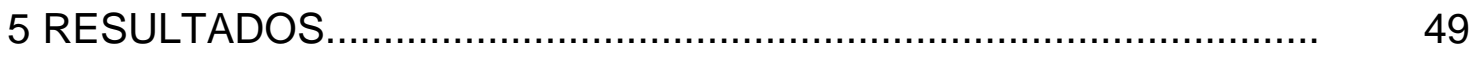

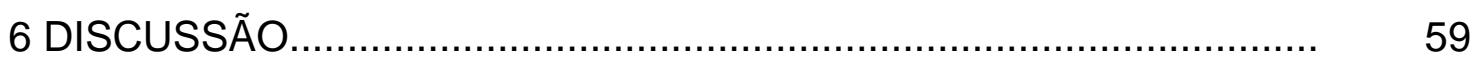

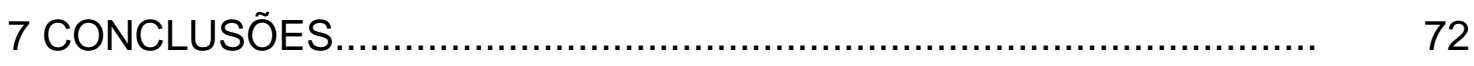

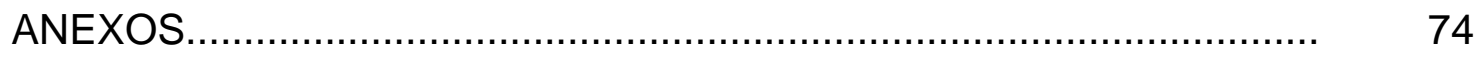

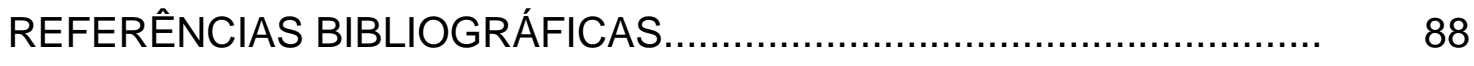

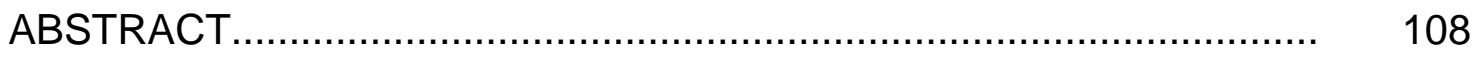

APÊNDICE 


\section{LISTA DE TABELAS}

pág

Tabela 1 Distribuição dos dentes dentro dos grupos experimentais 38

Tabela 2 Comparação entre o terço médio e apical, independente, das técnicas ou das soluções quanto a presença de smear layer

50

Tabela 3 Comparação global das técnicas de instrumentação com

o hipoclorito de sódio $1 \%$ quanto à presença de smear layer no terço médio

51

Tabela 4 Comparação global das técnicas de instrumentação com o hipoclorito de sódio 1\% quanto à presença de smear layer no terço apical

Tabela 5 Comparação global das técnicas de instrumentação com o hipoclorito de sódio $1 \%$ quanto à presença de smear layer independente do terço

Tabela 6 Comparação global das técnicas instrumentação com o gluconato de clorexidina $0,12 \%$ quanto à presença de smear layer no terço médio

Tabela 7 Comparação global das técnicas de instrumentação com o gluconato de clorexidina $0,12 \%$ quanto à presença de smear layer no terço apical 
Tabela 8 Comparação global das técnicas instrumentação com o gluconato clorexidina 0,12\% quanto à presença de smear layer independente do terço

Tabela 9 Comparação global das técnicas de instrumentação utilizadas, independentes das soluções, na limpeza das paredes dos canais radiculares no terço médio

Tabela 10 Comparação global das técnicas de instrumentação utilizadas, independentes das soluções, quanto a presença de smear layer no terço apical

Tabela 11 Comparação global das técnicas de instrumentação utilizadas, independentes das soluções e terço, quanto à presença de smear layer.

Tabela 12 Comparação da presença de smear layer nas paredes dos canais radiculares das soluções químicas auxiliares empregadas, hipoclorito de sódio $1 \%$ e gluconato de clorexidina $0,12 \%$, independente da técnica utilizada no terço médio

Tabela 13 Comparação da presença de smear layer nas paredes dos canais radiculares das soluções químicas auxiliares empregadas, hipoclorito de sódio $1 \%$ e gluconato de clorexidina $0,12 \%$, independente da técnica utilizada no terço apical 
Tabela 14 Comparação da presença de smear layer nas paredes dos canais radiculares das soluções químicas auxiliares empregadas, hipoclorito de sódio $1 \%$ e gluconato de clorexidina $0,12 \%$, independente da técnica utilizada, visão global 


\section{LISTA DE FIGURAS}

pág

$\begin{array}{lll}\text { Figura } 1 & \text { ProTaper } & 41\end{array}$

Figura 1.1 Instrumento F3 41

Figura 1.2 Fotomicroscopia da parte ativa do instrumento F3 41

Figura 1.3 Fotomicroscopia da ponta do instrumento F3 41

$\begin{array}{lll}\text { Figura } 2 \text { Instrumento } \mathrm{RaCe}{ }^{\circledR} & 43\end{array}$

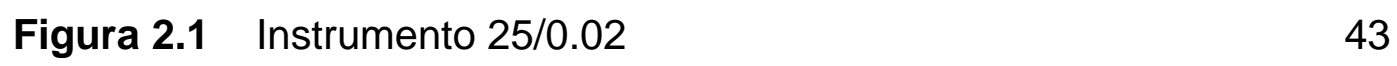

Figura 2.2 Fotomicroscopia da parte ativa do intrumento 43 25/0.02

Figura 2.3 Fotomicroscopia da ponta do instrumento 25/0.02 43

Figura 3 Instrumento $K^{3} \circledR \quad 44$

$\begin{array}{lll}\text { Figura } 3.1 \text { Instrumento 30/0.06 } & 44\end{array}$

Figura 3.2 Fotomicroscopia da parte ativa do instrumento 44 $30 / 0.06$

Figura 3.3 Fotomicroscopia da ponta do instrumento 30/0.06 44

Figura 4 Fotomicrografias com os respectivos escores (0 a 4), o qual foram entregues aos examinadores 


\section{LISTA DE ABREVIATURAS E SÍMBOLOS}

EDTA

$x$

$\%$

0

${ }^{\circ} \mathrm{C}$

rpm

(R)

$\mathrm{D}_{0}$

DC

$\mathrm{mL}$

$\mu \mathrm{m}$

N

MEV

$\mathrm{mm}$

$\mu \mathrm{A}$

$\mathrm{Kv}$

Ácido Etileno Diamino tetracético

número de vezes do aumento. Por exemplo: 1000x

aumento em 1000 vezes.

porcentagem (por cento)

graus

graus Celcius

rotações por minuto

marca registrada e patenteada

diâmetro inicial

diâmetro cirúrgico

miliLitro

micrometro

Newton

Microscopia Eletrônica de Varredura

milímetro

microAmpere

kilovolt 
Comparou-se a eficiência da instrumentação rotatória e manual-mecânica variando a substância auxiliar nos terços médio e apical quanto à presença da smear layer. Foram utilizados 95 dentes divididos em 4 grupos: Instrumentação manual-mecânico, Instrumentação com o sistema ProTaper, sistema RaCe e sistema $\mathrm{K}^{3}$, sendo os grupos irrigados com clorexidina $0,12 \%$ e hipoclorito de sódio $1 \%$, tendo 15 dentes como controle. Ao final os dentes foram clivados em seu longo eixo, metalizados e levados ao MEV. Os resultados mostraram que não houve diferença entre os terços analisados, independente das técnicas ou das soluções. Frente à solução de hipoclorito, no terço médio e análise global, o sistema $\mathrm{K}^{3}$ mostrou melhores resultados. No terço apical não houve diferença estatística. Não houve diferença estatística entre as técnicas no terço médio, apical e global, quando irrigados com a Clorexidina. A análise das técnicas de instrumentação, independente das soluções e dos terços, mostrou não haver diferença estatística. A clorexidina se mostrou superior ao hipoclorito no terço médio independente da técnica de instrumentação e no terço apical as duas soluções se equipararam. 
A Endodontia desempenha importante papel na preservação dos dentes e sua, conseqüente, manutenção na cavidade bucal.

O tratamento dos canais radiculares consiste, basicamente, de três fases: acesso à câmara pulpar e canal radicular, preparo biomecânico e obturação dos canais ${ }^{105,135}$.

O preparo biomecânico é fator de fundamental importância para o sucesso da terapia endodôntica e deve ser conduzido por meio dos recursos mecânicos da instrumentação com o auxílio, simultâneo, da irrigação com o objetivo de remoção do tecido pulpar e resíduos da cavidade pulpar, eliminar e/ou reduzir o número de microrganismos, retificar, dilatar e alisar as paredes dos canais radiculares para posterior obturação ${ }^{95}$.

Assim, cabe ao instrumento a responsabilidade da criação de um canal cirúrgico que contenha o anatômico, com forma final tronco-cônica, cujo menor diâmetro, no terço apical, favoreça o travamento do cone principal de guta percha e contribua para o adequado selamento do canal radicular, quando na fase de obturação ${ }^{123}$.

Logo, é inquestionável, o papel desenvolvido pelos instrumentos endodônticos durante o preparo do canal radicular, no entanto, é inegável a importância do emprego de determinadas substâncias químicas em procedimentos auxiliares $^{21,96,130 .}$

Com o intuito de se alcançar uma biomecânica cada vez mais eficiente, tem sido proposto diferentes técnicas e métodos de instrumentação associados as mais diversas substâncias químicas auxiliares, objetivando exercer ação desinfetante, facilidade de limpeza e ação dos instrumentos durante a terapêutica endodôntica. Tal preparo foi por muitos anos realizado manualmente, por meio de técnicas em que se utilizavam instrumentos de calibres mais finos para os mais calibrosos, seqüencialmente, até a dilatação apical, denominado de técnica clássica, que deixava o canal radicular com formato cônico ${ }^{4,36}$.

No ano de 1969, CLEM $^{35}$ preconizou uma técnica, de instrumentação mais conservadora em nível apical e uso de instrumentos 
mais calibrosos no preparo dos terços cervical e médio, favorecendo a desinfecção e alargamento do canal de forma cônica demonstrando ser mais eficiente que as técnicas clássicas.

SCHILDER ${ }^{123}$, em 1974 já citava que o sucesso do tratamento endodôndico estava diretamente ligado, além da desinfecção, ao correto preparo do canal radicular, sendo que a garantia da qualidade no preparo se traduz na manutenção da forma cônica do canal e do forame em sua posição original, tanto quanto possível na forma e tamanho.

Dentro das etapas do preparo do canal radicular, a limpeza e a modelagem realizadas manualmente, consomem grande tempo de trabalho com desgaste físico do profissional e do paciente. Conseqüentemente, não tardou para as industrias, buscando diminuir o tempo requerido e simplificar o preparo dos canais, lançarem várias peças automatizadas, juntamente com alterações introduzidas na morfologia.

Em 1988, WALIA; BRANTLEY; GERSTEIN ${ }^{141}$ preconizaram a utilização de uma nova liga metálica à base de níquel-titânio, para a confecção de instrumentos endodônticos manuais e rotatórios, pois essa liga apresenta flexibilidade duas a três vezes superior ao aço inoxidável além de uma maior resistência à fratura, diminuindo as dificuldades da instrumentação em canais curvos, sem comprometer os princípios que regem o sucesso da terapia endodôntica ${ }^{29,122}$.

A despeito das vantagens apresentadas pelos instrumentos de níquel-titânio os sistemas rotatórios prometem o aprimoramento e simplificação da Endodontia na prática clínica empregando materiais com características especiais com o intuito de amenizar as dificuldades inerentes à terapia endodôntica. Algumas características são atribuídas a esses instrumentos como o ajuste à anatomia do canal, promovendo desgaste seletivo e conferindo segurança, bem como contribuindo para a redução do tempo de trabalho durante a terapia endodôntica.

No mercado são encontrados diferentes sistemas rotatórios, com os mais diversos desenhos anatômicos e características inerentes de função e funcionamento, que trabalham sob condições opcionais de 
velocidade (rpm) e torque. O desenvolvimento de instrumentos à base de níquel-titânio trouxe grandes vantagens, especialmente quanto aos acionados a motor (instrumentos rotatórios). Esses instrumentos rotatórios mostram-se eficientes em modelar o canal radicular, preservando a forma cônica, com menor risco de acidentes.

Dentro o arsenal endodôntico atentamos para o sistema ProTaper ${ }^{\circ}, \mathrm{RaCe} \circledast$ e $\mathrm{K} 3 \AA$.

O sistema ProTaper ${ }^{\circledR}$ é constituído por seis instrumentos que possuem conicidade variável, ponta inativa, secção cordiforme, ângulo helicoidal em torno de $60^{\circ}$ e não possuem radial land. Os três primeiros instrumentos são denominados modeladores (Shaping files) e servem para o preparo do terço cervical e médio e três finais de acabamento (Finishing files) para preparo do terço apical. Os instrumentos de acabamento são divididos em F1,F2 e F3. O instrumento F1 possui conicidade de $7 \%$ entre $D_{0}$ a $D_{3}$ e $5,5 \%$ de $D_{4}$ a $D_{16}$. O F2 conicidade de $8 \%$ entre $D_{0}$ a $D_{3}$ e $4 \%$ de $D_{4}$ a $D_{16}$. Já o $F 3$ apresenta conicidade de $9 \%$ entre $D_{0}$ a $D_{3}$ e $5 \%$ entre $D_{4}$ a $D_{15}$.

O sistema $\mathrm{RaCe}{ }^{\circledR}$ (Reamer with Alternating Cutting Edges Alargador com arestas de corte alternadas) fabricado pela FKG possui seção reta transversal triangular ${ }^{119}$, ponta inativa e conicidade variável. A seção reta transversal, com aproximadamente $60^{\circ}$, Ihe confere grande poder de corte dentinário ${ }^{23,114}$. Os instrumentos são divididos em: Pré $\mathrm{RaCe}{ }^{\circledR}$ e $\mathrm{RaCe}{ }^{\circledR}$. Os Pré $\mathrm{RaCe}{ }^{\circledR}$ são indicados para o preparo cervical dos canais e os instrumentos $\mathrm{RaCe} \otimes$ são indicados no preparo dos terço médio e apical.

O sistema $\mathrm{K}^{3} \circledast$ oferece instrumentos com conicidades de $0.02 \mathrm{a}$ 0.06 nos comprimentos de 21, 25 e 30 mm e nos diâmetros de 15 a 60. A ponta é arredondada, sendo o ângulo de corte inferior entre 40 a $45^{\circ}$, possuindo um leve ângulo positivo de corte. O sistema apresenta alargadores cervicais, com conicidades entre 0.08 e 0.10 com o intuito do preparo do terço cervical e instrumentos para preparo do terço médio e apical com numeração de 15 a 60 e conicidades de 0.02 a $0.06{ }^{117}$. 
A ação dos instrumentos, manuais ou rotatórios, sobre a dentina faz com que a matriz mineralizada se fragmente, originando debris. Debris é definido como sendo lascas de dentina e restos orgânicos de tecido pulpar, necrótico ou não, depositado ao longo da parede do canal radicular $^{74}$, que se espalham sobre as paredes dentinárias, formando uma camada de 1 a $2 \mu \mathrm{m}$ de espessura, conhecida como smear layer. Smear layer é constituído, principalmente, por partículas inorgânicas com estrutura globular de diâmetro aproximado de 0,05 a 0,1 $\mu^{90}$ e é formada durante a ação dos instrumentos endodônticos na parede do canal radicular 64 , conseqüentemente, em áreas não atuadas pelos instrumentos, não há presença da mesma ${ }^{149}$, sendo que sua presença ou ausência pode de alguma forma influir na permeabilidade dentinária ${ }^{53}$, $98,100,150$

A irrigação acompanhada pela aspiração é um precioso método auxiliar do preparo do canal radicular. Enquanto o instrumento atua excisionando a dentina e modelando a forma do canal radicular, as soluções irrigantes atuam sobre os debris presentes no interior do sistema de canais radiculares, bem como sobre os componentes orgânicos e inorgânicos da smear layer e smear plug (tampão que se estende alguns micrometros para dentro dos túbulos dentinários). As soluções irrigantes agem também pela ação hidráulica, pois sua simples circulação, irrigação e aspiração eliminam os debris do interior dos canais radiculares ${ }^{21}$.

O gluconato de clorexidina é um anti-séptico catiônico pertencente ao grupo de compostos químicos chamados bisbiguanidas ${ }^{3,5}$ reconhecido por sua confiável atividade antimicrobiana, fungicidas e bactericidas ${ }^{71}$ sendo utilizada como anti-séptico oral na forma de enxagüante, constituinte de pasta dentária e chicletes desde $1950^{40,46,140 .}$

É uma base forte, carregada positivamente e pouco solúvel em água, sendo por isso empregada na forma de sal. O sal digluconato, em várias concentrações, é o mais utilizado em Odontologia, em qualquer de suas formas de apresentação. O sal de digluconato de clorexidina é 
altamente solúvel em água e ao atuar em pH fisiológico, dissocia-se e libera moléculas de cargas positivas. Esta substância foi descoberta por cientistas que buscavam um agente antimalária na década de 40, mas ela nunca foi utilizada para esse fim, Em 1959, a clorexidina começou a ser empregada, de forma tópica, na Europa para controle de placa. Somente em 1976, um estudo considerado como marco, popularizou o uso da clorexidina na Odontologia ${ }^{80}$. Entretanto, anos antes, mais especificamente na data de 1964 essa substância foi utilizada para irrigação de canais radiculares, porém seu emprego mais sistemático na Endodontia e avaliação de suas propriedades ocorreu a partir de $1982^{42}$.

A clorexidina quando em baixas concentrações, seu efeito é bacteriostático. Sua carga positiva se liga à carga negativa da parede da célula bacteriana, alterando o equilíbrio osmótico celular e fazendo com que haja perda das substâncias intracelulares de baixo peso molecular ${ }^{46}$, 79. Em altas concentrações ela é bactericida e faz com que o citoplasma da célula se precipite, o que resulta em morte celular ${ }^{79}$.

A clorexidina apresenta substantividade maior que o hipoclorito de sódio, embora não possua ação dissolvente tecidual do hipoclorito de sódio, a clorexidina apresenta ausência relativa de toxicidade, podendo ser empregada em pacientes alérgicos ao hipoclorito de sódio, ou em casos de dentes com ápices abertos, em que o extravasamento de hipoclorito de sódio para os tecidos perirradiculares poderia causar dor e inflamação ${ }^{48}$. Essas propriedades fazem com que o gluconato de clorexidina seja uma opção, de considerável valor, como solução química auxiliar da instrumentação ${ }^{49}$.

Visto que, a literatura científica relata os mais distintos resultados entre os métodos manuais e mecânicos rotatórios concernente à modelagem, limpeza e desinfecção do sistema de canais radiculares, é oportuno analisar a ação dos diferentes métodos de instrumentação manual e automatizado na presença de smear layer nas paredes do canal principal de dentes com achatamento proximal variando-se, também, a solução química auxiliar da instrumentação. 
As condições de limpeza do canal radicular tem sido alvo de várias pesquisas e observações. A limpeza da parede e túbulos do sistema de canais radiculares constitui fator de fundamental importância para 0 sucesso na terapia intracanal e consiste na remoção de debris e smear layer de modo a permitir contato mais íntimo da solução medicamentosa e do material obturador; uma vez que a presença dessa massa de componentes orgânicos e inorgânicos limita a ação de limpeza e desinfecção que os fármacos de uso endodôntico devem desempenhar e o, futuro, selamento promovido pelo cimento obturador radicular. Fica bastante previsível que a jornada, por parte de pesquisadores, torna-se incessante no sentido de obter técnicas soluções auxiliares do canal radicular o qual promovam tal objetivo, sendo concomitantemente utilizadas com algumas técnicas simples e rápidas até as mais complexas e demoradas de instrumentação do canal radicular, conforme mostra a literatura a seguir.

\subsection{Substâncias químicas auxiliares da instrumentação.}

Com o passar dos anos, vários experimentos e revelações foram feitos na área das soluções irrigantes de canais radiculares; como os de DAKIN ${ }^{39}$, em 1915 que trabalhou com uma solução anti-séptica à base de hipoclorito de sódio derivado da água de Jávali, por fim, finalizando suas pesquisas com a concentração de 0,5\% neutralizado com ácido bórico. A finalidade de associar um ácido à solução era diminuir o pH deixando-o mais próximo do neutro. De acordo com BARRET ${ }^{18}$ em 1917, a capacidade anti-séptica da solução era devida à reação química com as proteínas presentes nos tecidos, resultando na formação de cloramina.

McCLELLAND; WASS ${ }^{90}, 1922$ investigando o poder germicida e desinfetante de compostos halogenados (iodeto de cloro, dicloramina T em várias concentrações e solução de Dakin), concluíram que soluções de hipoclorito de sódio são muito instáveis e perdem rapidamente o poder germicida quando em contato com a luz e o ar. Logo, recomendaram que tais soluções deveriam ser protegidas da luz, do ar, em vidro de cor âmbar e fechado hermeticamente. 
No ano de 1936, WALKER ${ }^{142}$ publicou um artigo intitulado "Uma definitiva e confiável terapia para dentes despolpados", no qual o autor baseado na sugestão do Dr. Blass da Universidade de Nova Iorque, preconizou o uso do hipoclorito de sódio a 5\% para irrigação dos canais radiculares de dentes despolpados, uma vez que a solução é excelente solvente orgânico e altamente germicida. Nesse trabalho, nota-se uma preocupação com o controle da cadeia asséptica durante o tratamento, fato até então não observado.

Entre vários agentes químicos, GROSSMAN; MEIMAN ${ }^{67}, 1941$ propuseram-se a analisar o ácido sulfúrico ${ }^{28}$, hidróxido de sódio e potássio metálicos ${ }^{121}$, peróxido de sódio ${ }^{77}$, metilato de sódio, papaína e a soda clorada ${ }^{142}$ quanto à capacidade de desintegração do tecido pulpar. Os estudiosos ratificaram WALKER ${ }^{142}$ afirmando que a soda clorada foi mais eficiente como solvente pulpar, seguido pelo hidróxido de potássio, ácido sulfúrico 50\%, hidróxido de sódio, ácido clorídrico e, por último, a papaína. Os resultados para o peróxido de sódio, metilato de sódio e sódio e potássio metálico foram omitidos devido à instabilidade dos mesmos em meio aquoso.

STEWART ${ }^{135}$, 1955 analisou in vivo a importância do preparo químico-mecânico durante a terapêutica endodôntica. Cinqüenta dentes anteriores de pacientes que apresentavam algum tipo de sinal e ou sintoma como fístula, lesão periapical visível radiograficamente, polpas expostas à cavidade bucal ou dor foram analisadas. $\mathrm{Na}$ fase da instrumentação, o canal radicular era irrigado com peróxido de hidrogênio $3 \%$ seguido por hipoclorito de sódio 5\% (soda clorada). Os resultados mostraram que a técnica é eficiente para o controle da infecção bacteriana, limpeza e remoção de restos necróticos promovendo o fechamento de fístula e eliminação da dor dos pacientes examinados.

BAKER et al. ${ }^{13}$, em 1975 avaliaram por meio de microscopia eletrônica de varredura o poder de limpeza de várias soluções irrigantes em 48 dentes unirradiculares humanos assim divididos: grupo 1- não houve irrigação; grupo 2- 1,0 ml de solução salina; grupo 3- 5,0 ml de 
solução salina; grupo 4- 0,5 $\mathrm{ml}$ de solução salina; grupo 5- 2,5 ml de peróxido de hidrogênio 3\% e 2,5 ml de hipoclorito de sódio 1\%; grupo 61,0 $\mathrm{ml}$ de peróxido de hidrogênio 3\%; grupo 7- 5,0 $\mathrm{ml}$ de peróxido de hidrogênio 3\%; grupo 8-1,0 ml de hipoclorito de sódio 1\%; grupo 9- 5,0 ml de hipoclorito de sódio 1\%; grupo 10-1,0 ml de Gly-oxide (peróxido de uréia 10\% em glicerina anidra); grupo 11- 5,0 ml Gly-oxide; grupo 12- 0,5 $\mathrm{ml}$ Gly-oxide e 0,5 $\mathrm{ml}$ de hipoclorito de sódio 1\%; grupo 13- 2,5 ml Glyoxide e 2,5 ml de hipoclorito de sódio 1\%; grupo 14- 1,0 ml RC - Prep®; grupo 15- 5,0 ml RC - Prep®; grupo 16- 0,5 ml RC - Prep® e 0,5 ml de hipoclorito de sódio 1\%; grupo 17- 2,5 ml RC - Prep® 2,5 ml de hipoclorito de sódio 1\%; grupo 18- 1,0 ml EDTA 15\%; grupo 19- 5,0 ml de EDTA 15\%; grupo 20- 0,5 ml de EDTA e 1,0 ml de hipoclorito de sódio 1\%; grupo 21- 2,5 ml de EDTA 15\% e 2,5 ml de hipoclorito de sódio 1\%; grupo 22- 5,0 ml de hipoclorito de sódio 1\% por uma hora; grupo 23-1,0 ml de hipoclorito de sódio 1\% e 1,0ml de fluoreto de sódio; grupo 24- 5,0 ml de hipoclorito de sódio 1\%; grupo 25- 5,0 ml de fluoreto de sódio 1\%. Após análise de 775 fotomicrografias tomadas em vários níveis, tanto dos dentes controles como dos instrumentados e irrigados, concluiu-se que não havia diferença de uma solução para a outra na remoção de debris. As substâncias quelantes, aparentemente, mostraram capacidade de alterar a morfologia de túbulos dentinários e apresentaram-se mais eficazes na promoção da limpeza em relação aos demais. Os autores comentam que a remoção de debris e dos microrganismos deve-se principalmente à quantidade e não ao tipo de solução utilizada. Salientam ainda que, o encontro de soluções químicas compatíveis biologicamente com tecidos periapicais, recomenda-se o uso de solução salina para irrigar os canais radiculares.

$\mathrm{AUN}^{11}, 1979$ evidenciou e relatou que o uso do instrumento potencializa a ação antibacteriana da substância química, facilitando o seu contacto com a parede dentinária, fazendo-nos acreditar que a escolha e a utilização dos instrumentos endodônticos em muito contribui para o sucesso da terapia instituída. Desde a introdução dos primeiros 
instrumentos fabricados com finalidade endodôntica, modificações têm sido introduzidas e novos desenhos têm sido criados, sendo que os mais amplamente utilizados são as limas tipo $\mathrm{K}$ pela versatilidade apresentada.

ABOU-RASS; OGLESBY ${ }^{2}$ no ano de 1981 investigaram a capacidade solvente de tecidos conjuntivos de ratos de diferentes concentrações de hipoclorito de sódio em temperaturas variadas. Os autores estavam interessados em saber se a velocidade de dissolução dos tecidos era diretamente proporcional à concentração de hipoclorito de sódio e à temperatura. Outra dúvida era se o estado do tecido (fresco, fixado ou necrótico) influenciaria na eficácia do hipoclorito de sódio. Para isso, foram utilizados 120 espécimes (tecido conjuntivo da derme de ratos) cortados em 1 a $2 \mathrm{~mm}$ de altura e $8 \mathrm{~mm}$ de diâmetro. As amostras foram dividas em três grupos de quarenta cortes: a) tecido conjuntivo fresco, b) tecido conjuntivo fixado com formocresol por 8 dias, c) tecido conjuntivo necrótico. As concentrações da solução de hipoclorito de sódio eram de $5,25 \%$ e $2,6 \%$, à temperatura de $22,9^{\circ} \mathrm{C}$ e $60^{\circ} \mathrm{C}$. Após análise dos resultados, concluiu-se que a concentração mais alta de hipoclorito de sódio apresentou melhores resultados. O aumento da temperatura da solução de hipoclorito de sódio melhorou o poder de dissolver tecido sendo os mais fáceis de dissolver foram os frescos seguidos pelos necróticos e, por fim, os fixados.

RINGEL et al. ${ }^{110}, 1982$ realizaram um estudo in vivo com o intuito de investigar e comparar a eficácia antimicrobiana das soluções de gluconato de clorexidina a $0,2 \%$ e hipoclorito de sódio a 2,5\% na flora radicular como auxiliares da instrumentação do canal radicular. Para tanto foram selecionados 52 pacientes e tratados 60 dentes que apresentavam necrose pulpar e lesão periapical visível radiograficamente, sendo divididos em dois grupos iguais. As coletas microbiológicas foram realizadas antes, durante e depois do preparo biomecânico. Perante os resultados apresentados os autores concluem que a solução de hipoclorito de sódio $2,5 \%$ é mais bactericida que a clorexidina 0,2\% quando utilizada como solução auxiliar do preparo biomecânico, no 
entanto, a solução de gluconato de clorexidina não deve ser descartada, visto que apresenta propriedades importantes como adsorção, efeito prolongado e largo espectro de ação.

BAUMGARTNER; CUENIN ${ }^{19}$, 1992 realizaram um experimento usando microscopia eletrônica de varredura, para examinar a superfície do terço médio de canais radiculares instrumentados ou não e irrigados com solução de hipoclorito de sódio nas concentrações de 5,25; 2,5; 1,0 e 0,5\%. Observaram que as soluções de hipoclorito de sódio nas concentrações 5,$25 ; 2,5$ e 1,0\% removeram por completo os restos de tecido pulpar nos canais não instrumentados e a $0,5 \%$ foi capaz de remover grande parte, deixando apenas alguns remanescentes de tecido.

FACHIN et al. ${ }^{45}, 1994$ elaboraram uma revisão da literatura com enfoque clínico sobre o uso do hipoclorito de sódio na Endodontia, enfatizando alguns aspectos, como: ação solvente, reação tecidual, efeito bactericida, eficiência na remoção de resíduos e efeito da temperatura da solução. Assim sendo, terminam concluindo que a solução de hipoclorito de sódio a 1\%, em temperatura ambiente, se apresenta como uma opção clínica nos casos de necrose pulpar e biopulpectomias. O hipoclorito de sódio em baixa concentração apresenta equilíbrio entre efeito bactericida, estabilidade, ação solvente orgânica e biocompatibilidade.

GAVINI, AUN, PESCE ${ }^{57}$ em 1994 avaliaram, através da microscopia eletrônica de varredura, a capacidade do soro fisiológico, EDTA $17 \%$, ácido cítrico a 25\% e do hipoclorito de sódio a 1\% em diminuir a formação de smear layer ou facilitar sua remoção, empregados de maneira associadas e em diferentes volumes logo após o preparo do canal radicular. Foram selecionados 30 dentes humanos divididos em 5 grupos com 6 dentes cada, variando-se as soluções irrigantes e os volumes a serem testados: G1-soro fisiológico $6 \mathrm{ml}$, G2- EDTA 17\% $3 \mathrm{ml}$ e hipoclorito de sódio $3 \mathrm{ml}$, G3- EDTA 17\% $6 \mathrm{ml}$ e hipoclorito de sódio 1\% $6 \mathrm{ml}$, G4- ácido cítrico 25\% $3 \mathrm{ml}$ e hipoclorito de sódio $1 \% 3 \mathrm{ml}$, G5- ácido cítrico 25\% $6 \mathrm{ml}$ e hipoclorito de sódio $1 \% 6 \mathrm{ml}$. As análises dos resultados permitiram os autores inferir que os melhores resultados foram 
obtidos no grupo $\mathrm{G} 3$, seguido pelo $\mathrm{G} 5$, os terceiro e quarto lugares couberam, respectivamente, às amostras G2 e G4, sendo os resultados menos satisfatórios observados no G1. Conseqüentemente, relatam que existe importante diferença entre a natureza química e o volume das soluções irrigantes.

SPANÓ ${ }^{134}$ em 1999 estudou in vitro a dissolução do tecido pulpar bovino frente à solução de hipoclorito de sódio nas concentrações de 0,5; 1,0; 2,5 e 5,0\%. A tensão superficial e o teor de cloro, antes e depois da utilização dessas soluções no processo de dissolução também foram verificados neste trabalho. Com base na metodologia empregada e nos resultados obtidos, o autor concluiu que a velocidade de dissolução dos fragmentos do tecido pulpar bovino é diretamente proporcional à concentração das soluções de hipoclorito de sódio, ou seja, quanto maior a concentração das soluções de hipoclorito de sódio, tanto mais rápido se processa a dissolução do tecido pulpar. O porcentual de cloro remanescente das soluções de hipoclorito de sódio apresenta relação diretamente proporcional com a sua concentração inicial da solução, assim, quanto maior a concentração de cloro inicial de uma solução de hipoclorito de sódio, tanto maior a porcentagem de cloro remanescente.

Curiosos frente às características do gluconato de clorexidina, COSTA et al. ${ }^{37}$, 1999 avaliaram de forma comparativa o potencial de reparação do complexo dentino-pulpar, quando polpas de dentes de ratos foram mecanicamente expostas e capeadas como sistema adesivo Scotchbond MP com ou sem aplicação prévia de uma solução de clorexidina $0,2 \%$. Com a avaliação dos resultados, foi possível determinar que a reação do complexo dentino-pulpar, com ou sem a utilização da clorexidina, foi semelhante. Aos sete dias ocorreu necrose tecidual do corno pulpar, o qual foi mecanicamente exposto. Desta maneira, concluise, dentro das condições experimentais, que o uso da clorexidina não influenciou negativa ou positivamente no processo reacional de necrose do tecido pulpar de rato. 
SCELZA et al. ${ }^{116}$, 2000 realizaram um estudo in vitro para analisar, por meio de microscopia eletrônica de varredura, o grau de remoção de debris e smear layer de canais radiculares. As soluções irrigantes utilizadas foram: hipoclorito de sódio 1\% associado com ácido cítrico 10\% (irrigação final: água destilada), hipoclorito de sódio 0,5\% associado com EDTA-T 17\% e hipoclorito de sódio 5\% associado com peróxido de hidrogênio 3\% (irrigação final com hipoclorito de sódio 5\%). Destas, o hipoclorito de sódio 0,5\% associado com EDTA-T 17\% apresentou melhores resultados na remoção da smear layer, seguido pela associação de hipoclorito de sódio 1\% + ácido cítrico 10\% e hipoclorito de sódio 5\% + peróxido de hidrogênio 3\%.

BUCK et al. ${ }^{26}$ em 2001 verificaram a eficácia antimicrobiana in vitro de soluções químicas para irrigação do canal radicular: Hipoclorito de sódio 5,25\% e Clorexidina 0,12\% (Peridex). Os dentes e os canais foram contaminados com cepas de Enterococcus faecalis. Após análise dos resultados os autores puderam concluir que grandes quantidades de colônias bacterianas distantes do canal principal apresentavam vitais e que a solução de hipoclorito de sódio 5,25\% apresentou melhores resultados que a da clorexidina a $0,12 \%$, no entanto, não houve diferenças estatísticas entre os terços: cervical, médio e apical, nem entre o poder de penetração ao longo da massa dentinária.

FAVA; CONDE; SIQUEIRA Jr ${ }^{48}, 2001$ realizaram intensa revisão da literatura sobre a clorexidina e, terminam, relatando que devido as suas propriedades físico-químicas e biológicas a clorexidina tem algumas potenciais indicações endodônticas, dos quais se destaca o emprego como solução irrigante.

GOLDSMITH; GULABIVALA; KNOWLES ${ }^{60}$, 2002 realizaram um estudo com o propósito de avaliar a ação de diferentes concentrações de hipoclorito de sódio sobre a estrutura dentinária após irrigação em diferentes períodos. As concentrações estudadas foram 3\%, 5,1\% e 7,3\% sendo o grupo controle irrigado com solução salina. Os resultados obtidos revelaram que a irrigação com a solução de hipoclorito de sódio a 7,3\% 
não alterou a estrutura dentinária de maneira diferente que as concentrações de $5,1 \%$ e $3 \%$, inclusive apresentaram resultados similares, no entanto, as três concentrações apresentaram diferenças, quando comparadas ao grupo controle (solução salina).

SLUTZKY-GOLDBERG; LIBERMAN; HELING ${ }^{129}$, 2002 estudaram a microdureza dentinária após a instrumentação manual com limas tipo $\mathrm{K}$ e rotatória com o sistema ProFile 0.04 e irrigação com a solução de hipoclorito de sódio 2,5\%. Após análise dos resultados os autores observaram que houve diferença estatística entre as profundidades analisadas (500 $\mu \mathrm{m}$ e $1000 \mu \mathrm{m})$ sendo a primeira mais afetada, o grupo da instrumentação manual reduziu mais que o grupo do ProFile quando utilizado a mesma solução irrigante e que o contato da solução de hipoclorito de sódio a 2,5\% já alterou a microdureza dentinária, principalmente a $500 \mu \mathrm{m}$.

ATTIN et al. ${ }^{8}$, 2002 realizaram um estudo, in vivo, com o intuito de avaliar as propriedades da limpeza de canais radiculares sem instrumentação. Essa técnica foi denominada de Técnica Hidrodinâmica Sem Instrumentação. Foi descrita no início da década de noventa com resultados iguais ou superiores ao preparo biomecânico convencional. Para tanto os autores separaram 43 dentes que seriam extraídos por doença cariosa ou periodontal, sendo 22 unirradiculares e 21 multirradicular. Os dentes foram submetidos aos testes, sendo a irrigação dividida em três fases: terço cervical irrigado com ácido fosfórico 35\%, terço médio e apical irrigado com hipoclorito de sódio 3\% com irrigação final a 0,9\%. O tempo da irrigação durou 30 minutos sendo que a irrigação final com hipoclorito de sódio a 0,9\% durou 2 minutos. Posteriormente, os dentes foram extraídos e submetidos à análise histológica. Depois de analisados resultados os autores concluíram que a Técnica Hidrodinâmica Sem Instrumentação mostrou resultados distintos entre as pesquisas, o que desaconselha o uso da técnica, salvo se houver modificações.

NIU et al. ${ }^{94}$, 2002 analisaram in vitro a erosão dentinária causada pela irrigação final de EDTA e hipoclorito de sódio. Para isso, vinte e cinto 
dentes unirradiculares foram instrumentados com o sistema ProFile 0.04, sendo que os dentes foram divididos em cinco grupos: $\mathrm{G} 1$ - irrigação com hipoclorito de sódio 6\% (3 mL) por 2 minutos, G 2 - irrigação com EDTA 15\% (3 mL) por 2 minutos, G 3 - irrigação com EDTA 15\% (3 mL) por 1 minutos seguido pela irrigação de hipoclorito de sódio a 6\% (3 mL) por 2 minutos, G 4 - irrigação com EDTA 15\% por 3 minutos e G 5 - irrigação com EDTA 15\% (3 mL) por 3 minutos seguido por hipoclorito de sódio 6\% (3 $\mathrm{mL}$ ) por 2 minutos. As fotomicrografias foram realizados com aumento de 3000x retiradas a 1, 3 e 6 mm do ápice. Após análise dos resultados estatísticos os autores puderam concluir que a irrigação final com a solução de hipoclorito de sódio a 6\% acelera o processo de erosão e agressão à estrutura dentinária após o tratamento com EDTA 15\%, sendo que a irrigação somente com o hipoclorito não é suficiente para remoção da smear layer.

GAMBARINI; LASZKIEWICZ ${ }^{55}$, 2002 analisaram a presença remanescente de debris e da smear layer após utilização do sistema rotatório GT. Para tanto, foram utilizados 16 dentes pré-molares unirradiculares. Durante a instrumentação com o sistema GT substância irrigadora de eleição foi hipoclorito de sódio a 5\%, totalizando $2 \mathrm{~mL}$ por canal. Findo a etapa de instrumentação, os canais foram divididos em dois grupos: G 1 - irrigação com 2 ml de EDTA + Cetramida por um minuto e G 2 - $2 \mathrm{~mL}$ de hipoclorito de sódio por 5 minutos. A presença de debris e da smear layer foram analisadas, em microscopia eletrônica de varredura com aumento 200x e 1000x, respectivamente. Após análise estatística dos resultados os autores concluíram que o sistema GT foi eficiente na remoção de debris, no entanto, foi ineficaz na remoção da smear layer, principalmente no terço apical.

CHAVES $^{31}, 2002$ avaliou in vitro a presença de debris nas paredes dentinárias após a instrumentação com os géis de clorexidina $2 \%$ e de mamona, com auxílio da microscopia eletrônica de varredura. Para tanto, vinte e quatro pré-molares inferiores unirradiculares foram selecionados e instrumentados manualmente com limas tipo K (Dyna-flex). Os dentes 
foram divididos em quatro grupos, sendo: Grupo I -gel de clorexidina 2\%; Grupo II - EDTAC 17\% misturado ao hipoclorito de sódio 1 \%; Grupo III gel de mamona e Grupo IV - hipoclorito de sódio 1 \%. Após o término da instrumentação, os dentes foram irrigados com água destilada, aspirados e posteriormente seccionados longitudinalmente. As fotomicrografias dos terços médio e apical foram avaliadas utilizando o programa Fotoscore e os dados submetidos à análise estatística. Os resultados mostraram que a mistura das soluções EDTAC 17\% com hipoclorito de sódio 1 \% foi capaz de remover por completo a smear layer das paredes dentinárias, produzida durante a instrumentação endodôntica, o hipoclorito de sódio 1 $\%$ e os géis de clorexidina $2 \%$ e de mamona não foram eficientes na limpeza dos canais radiculares, mostrando-se estatisticamente similares, não houve diferença estatística significante entre os terços médio e apical dos canais radiculares quanto à remoção da smear layer, independentemente da substância auxiliar utilizada no preparo químicomecânico dos canais radiculares, os géis de clorexidina a $2 \%$ e de mamona removeram os debris de forma semelhante ao verificado com o uso do hipoclorito de sódio a $1 \%$, nos terços médio e apical dos canais radiculares e que a mistura das soluções EDTAC 17\% com o hipoclorito de sódio a 1\% promoveu os melhores resultados, com canais radiculares livres de smear layer e debris.

MARCHESAN et al. ${ }^{86}, 2003$ verificou a qualidade de limpeza dos canais radiculares, por meio da microscopia óptica promovida pela técnica de instrumentação rotatória associada ao hipoclorito de sódio 0,5\%, HCT20 (solução aquosa de hidróxido de cálcio acrescida de detergente) e clorexidina $2 \%$, em canais achatados no sentido mésiodistal. Doze incisivos centrais inferiores humanos foram divididos aleatoriamente em três grupos para que fossem instrumentados com instrumentação rotatória (ProFile 0.04). A análise estatística evidenciou que os valores da porcentagem de limpeza para as diferentes soluções irrigantes foram estatisticamente diferentes entre si. Comparações duas a duas permitiram dispor as soluções irrigantes em ordem crescente de efetividade na 
limpeza, sendo: hipoclorito de sódio a 0,5\%, seguido pela clorexidina $2 \%$ e, por fim, pela HCT20.

SOUZA et al. ${ }^{132}, 2003$ avaliaram a capacidade de ação dos quelantes EDTA, EGTA e CDTA associados à solução de hipoclorito de sódio $1 \%$ e a $5,25 \%$, isoladamente, em remover a smear layer do terço apical do canal radicular. Para tanto foram utilizados 20 dentes que foram distribuídos em 4 grupos de 5 dentes cada. Após instrumentação (técnica mista invertida) e irrigação com água destilada deionizada os dentes foram crivados em secção longitudinal e os canais radiculares foram irrigados com $3 \mathrm{~mL}$ de EDTA 17\%, CDTA 1\%, EGTA 1\% e hipoclorito de sódio 5,25\% por 3 minutos. A eficácia na remoção da smear layer foi analisada por microscópio eletrônico de varredura (2500x) e os resultados mostraram-se, estatisticamente, melhores no grupo do EDTA 17\% seguido pelo grupo do EGTA 1\% e CDTA 1\%, sendo que o hipoclorito de sódio 5,25\% não foi eficiente.

FERGUSSON et al. ${ }^{49}, 2003$ realizaram um estudo in vitro com 100 dentes humanos, unirradiculares com a finalidade de avaliar o efeito do gluconato de clorexidina $0,12 \%$ como solução irrigante do canal radicular no selamento apical pelo método de penetração fluida num período de 270 e 360 dias. Os dentes foram divididos em 3 grupos de acordo com a solução irrigante: solução salina, hipoclorito de sódio 5,25\% e clorexidina 0,12\%. E em dois subgrupos: 270 e 360 dias. Após o preparo biomecânico com lima calibre \# 50 e obturação com três cimentos endodônticos diferentes (Roth 811, AH 26 e Selapex) do sistema de canal radicular os dentes foram analisados conforme metodologia proposta. Os resultados obtidos relataram que o gluconato de clorexidina 0,12\% quando utilizado com solução irrigante dos canais radiculares não influi no processo de selamento apical dos cimentos endodônticos estudados.

FRÖNER ${ }^{52}$, 2003 avaliou a limpeza de pré-molares inferiores após instrumentação manual e ultra-sônica utilizando diferentes soluções irrigantes. Sendo EDTAC 17\% hipoclorito de sódio 1\%, solução de clorexidina $2 \%$ e detergente derivado da mamona 3,3\% (Endoquil). Os 
resultados mostraram que não houve diferença estatística entre a clorexidina 2\%, hipoclorito de sódio 1\% e o Endoquil independente da técnica de instrumentação utilizada. O EDTAC 17\% promoveu melhor limpeza do terço apical dos canais radiculares quando empregado na técnica manual. Sendo que para a técnica de instrumentação ultra-sônica não houve diferenças significantes entre todas as soluções avaliadas e que, também, não houve diferenças estatísticas entre a técnica manual e ultra-sônica independente da solução irrigadora. A autora conclui que a melhor limpeza foi verificada com a utilização do EDTAC 17\% na técnica da instrumentação manual e termina relatando que o alto volume de solução irrigante empregado pode ter sido o fator que promoveu limpeza semelhante no terço apical entre a técnica de instrumentação manual e ultra-sônica quando utilizado o hipoclorito de sódio 1\%, clorexidina $2 \%$ e 0 Endoquil.

BARATTO FILHO et al. ${ }^{14}, 2004$ realizaram um estudo morfométrico com o objetivo de avaliar a eficácia da instrumentação do sistema ProFile em diferentes concentrações de hipoclorito de sódio, 0,5; 1,0 e 5\%, sendo a água destilada o grupo controle. Após o preparo biomecânico, os dentes foram submetidos ao preparo histológico e analisados morfometricamente. A referida análise revelou que a solução de hipoclorito de sódio $5 \%$ foi mais eficiente em remover debris do canal radicular.

SIQUEIRA ${ }^{127}$ em 2004 avaliou a capacidade de dissolução de polpas de dentes bovinos em clorexidina a $2 \%$, veiculada em gel de Natrosol e pela solução de hipoclorito de sódio (em diferentes concentrações e valores de $\mathrm{pH}$ ); sob duas diferentes temperaturas. Os fragmentos do tecido pulpar foram imersos no digluconato de clorexidina a 2\% e hipoclorito de sódio a 5,0\%; 2,5\%; 1,0\% e 0,5\%, com valores de pH ajustados em 7,0; 9,0 e 11,0; sob duas diferentes temperaturas: 27 e $37^{\circ} \mathrm{C}$, monitorados em incubadora, para período máximo de 120 minutos. Duas amostras de fragmentos pulpares foram colocadas em água destilada, sob as duas temperaturas, servindo como controles. Os 
resultados mostraram que: as soluções de hipoclorito de sódio sofrem influência do $\mathrm{pH}$, temperatura e concentração no agir sobre a dissolução do tecido pulpar bovino. A clorexidina a $2 \%$, bem como, as soluções de hipoclorito de sódio a $0,5 \%\left(\mathrm{pH} 7\right.$ e temperatura entre 27 e $\left.37^{\circ} \mathrm{C}\right)$, não dissolveram o tecido durante o tempo experimental de 120 minutos. Seria conveniente que as pesquisas que envolvam o hipoclorito de sódio em Endodontia especificassem suas características de $\mathrm{pH}$, temperatura e concentração. Em pH 11, podem-se utilizar soluções menos concentradas de hipoclorito de sódio para manter sua capacidade de dissolução tecidual. Apesar de não haver um modelo ideal para aquecimento controlado de soluções de hipoclorito de sódio, essas devem ser aquecidas para aumentar sua eficácia sobre a dissolução de tecidos, por fim, para se potencializar o efeito de dissolução de tecidos por soluções de hipoclorito de sódio, deve-se optar em primeiro lugar pela elevação do $\mathrm{pH}$, seguido do aquecimento da mesma e por último aumentar sua concentração.

BARDAL $^{17}, 2005$ analisou a ocorrência de um efeito colateral da clorexidina - o manchamento extrínseco do esmalte dentário - e a prevalência de cálculo dentário. Um total de 83 pacientes (13 a 32 anos de idade) participaram desse estudo clínico randomizado. Os participantes utilizaram por 3 meses os respectivos dentifrícios de acordo com seu grupo: grupo A - Sorriso Fresh Red Mint, 1100 ppm F (NaF) Kolynos do Brasil Ltda; grupo B - dentifrício experimental com 1100 ppm F (NaF) e clorexidina $0,95 \%$ (digluconato de clorexidina) e grupo $\mathrm{C}$ dentifrício experimental com clorexidina $0,95 \%$ (digluconato de clorexidina) - FGM , Joinville. Foi observado um aumento estatisticamente significante do índice de manchas, no entanto não houve aumento dos valores referentes ao cálculo dentário nos grupos B e C.

\subsection{Instrumentação do canal radicular - técnicas e métodos.}

Com o propósito de avaliar o papel da instrumentação (limagem) durante o preparo dos canais radiculares, INGLE; ZELDOW ${ }^{75}$ em 1958, realizaram um estudo in vivo em 89 dentes unirradiculares com polpa 
mortificada. Os dentes eram instrumentados e irrigados somente com água destilada estéril. Após análise dos resultados, os autores constaram que apenas uma pequena porcentagem (4,6\%) apresentou cultura negativa para o crescimento bacteriano. Conseqüentemente, a maioria (95,4\%) apresentou cultura positiva. Logo, concluiu-se que instrumentação mecânica e irrigação com água destilada são métodos ineficientes para descontaminar canais radiculares.

AUN, PAIVA, ANTONIAZZI ${ }^{11}, 1990$ avaliaram, através da microscopia eletrônica de varredura, a limpeza da parede do canal radicular (terço apical), após o preparo químico-mecânico, tendo como fonte de variação o tipo e o número de uso de instrumentos. Para tanto, foram selecionados 32 dentes humanos unirradiculares que foram divididos em dois grupos com 16 dentes cada instrumentados com limas tipo K (G1) e tipo K-Flex (G2), sendo que estes foram divididos em 4 subgrupos de 4 dentes cada, acorde o número de uso do instrumento no preparo endodôntico. Os resultados mostraram que houve diferença estatisticamente significante no que tange à capacidade de propiciar uma superfície dentinária intracanal livre de smear layer e debris, quando se compara a lima tipo $\mathrm{K}$ e K-Flex, sendo que esta proporciona sempre um número maior de canalículos dentinários visíveis (descobertos) e que 0 número de uso do instrumento também exibe variação significante com relação ao número de canalículos observáveis, ou seja, quanto maior o número de uso do instrumento, tanto maior o número de canalículos dentinários expostos (tanto menor a smear layer e debris).

De DEUS et al. ${ }^{41}$, 2000 executaram um trabalho que teve como objetivo analisar a capacidade de remoção de smear layer e debris, no terço apical, comparando-se duas técnicas de instrumentação a Técnica Anatômica Simplificada e a Escalonada (Step back). Para tanto foram selecionados vinte e seis raízes mésio-vestibulares de primeiros molares superiores. A análise da superfície dentinária foi realizada frente ao microscópio eletrônico de varredura, sendo 500x para análise de debris e 1000x para análise da smear layer. Sendo que os debris e a smear layer 
foram previamente definidos e, portanto, analisados distintamente. Os resultados demonstraram não haver diferenças entre os dois grupos em relação a smear layer, a Técnica Anatômica Simplificada apresentou uma melhor capacidade de remoção de restos orgânicos, sendo esta diferença estatisticamente significante, em todas as amostras, o terço apical nunca apresentou uma limpeza adequada, os melhores resultados na remoção de restos orgânicos encontrado pela Técnica Anatômica Simplificada são provavelmente devido a um maior alargamento e conicidade proporcionados por esta técnica e que a remoção de debris provavelmente está mais relacionada a um fator mecânico, enquanto que a remoção da smear layer está provavelmente mais relacionada a um fator químico.

Com auxílio de um poderoso instrumento de visualização, a tomografia microcomputadorizada, RHODES et al. ${ }^{109}, 2000$ analisaram um estudo comparativo de dois instrumentos de níquel-titânio para a instrumentação de dentes posteriores. Para tanto, foram utilizados dez primeiro molares inferior, totalizando trinta canais. Quinze canais foram instrumentados usando limas manuais NiTi-flex (Denstply-Maillefer) usando a técnica da força balanceada. Os outros quinze canais foram instrumentados com as limas do sistema ProFile conicidade 0.04 (Densply-Maillefer) na seqüência coroa-ápice até a lima ISO 25. Os resultados mostraram não haver diferença estatísticas entre a instrumentação manual com as limas NiTi-Flex e a rotatória como sistema ProTaper conicidade 0.04 para as variáveis testadas. Conseqüentemente, concluem que ambas técnicas produziram um preparo radicular com forma cônica progressiva e centralizada.

TEIXEIRA et al. ${ }^{137}$, 2001 realizaram um trabalho com o objetivo de avaliar a capacidade de remoção de smear layer dos canais radiculares, durante a instrumentação do canal radicular com limas Hedströen, empregando-se diferentes tipos de irrigantes endodônticos. Para tanto, foram utilizados 20 dentes, distribuídos entre quatro grupos: G1- EDTA 17\%, G2- Hipoclorito de sódio 5,25\%, G3- Endoquil (polímero à base de 
mamona) e o G4- sendo o grupo controle. Os dentes foram instrumentados, irrigados com a solução estudas e clivados, sendo as amostras submetidas à análise em microscopia eletrônica de varredura com aumento de 1000x. Os resultados mostraram que os grupos do EDTA $17 \%$ e Endoquil promoveram maior capacidade de remoção de smear layer durante a instrumentação, não diferindo estatisticamente entre si. A irrigação com o hipoclorito de sódio, durante a instrumentação, deixou a parede do canal instrumentado recoberta por resíduos orgânicos e inorgânicos, sendo o grupo da água apresentando os piores resultados.

PETERS, SCHÖNENBERGER; LAIB ${ }^{104}$, 2001 realizaram um estudo comparando a variação de volume anatômico e da superfície do canal radicular após instrumentação com três diferentes técnicas de preparo do canal radicular, sendo utilizada a microtomografia computadorizada como instrumento de visualização. Os espécimes foram analisados antes e depois da instrumentação manual com limas tipo $\mathrm{K}$ de níquel-titânio e com os sistemas rotatórios: ProFile 0.04, Lighspeed e GT. A solução química auxiliar foi hipoclorito de sódio 2,5\% alternado com EDTA 17\%. O batente apical foi finalizado com diferentes calibres de limas, conforme a técnica empregada e diâmetro anatômico do canal. Após análise dos resultados os autores observaram que as técnicas de instrumentação, testadas, apresentam cerca de $35 \%$ ou mais de superfície das paredes do canal radicular inalterada e concluem que houve diferenças estatísticas entre os grupos testados e que a anatomia do canal radicular tem grande influência na ação das limas.

GARCIA FILHO et al. ${ }^{56}, 2002$ avaliaram microscopicamente a eficiência de dois instrumentos rotatórios na limpeza do terço apical de canais curvos. Para tanto foram utilizados quarenta canais mesiais de vinte molares inferiores. Os canais foram instrumentados com os sistemas ProFile 0.04 Série 29 e Quantec SC. Os $3 \mathrm{~mm}$ apicais das raízes foram seccionados ao processamento histológico e corados. Todos os espécimes foram levados para análise em microscópio ótico (aumento de 40x). As imagens foram digitalizadas e transferidas ao programa Image 
Pro Plus for Windows para medição do perímetro do canal e áreas de resíduos. No Grupo I (ProFile) pôde-se observar 28,91\% de resíduos após a instrumentação, enquanto $20,02 \%$ de resíduos foram observados nos espécimes do Grupo II (Quantec). Após análise estatística dos resultados os autores concluíram que nenhum instrumento foi capaz de limpar completamente o terço apical dos canais e que a qualidade da limpeza está diretamente relacionada à anatomia do canal e não somente ao instrumento utilizado.

ROLLISON; BARNETT; STEVENS ${ }^{112}$, 2002 avaliaram a eficácia do preparo biomecânico em remover bactérias do canal radicular em função da técnica de instrumentação e da conicidade. Após análise dos resultados os autores puderam concluir que a instrumentação realizado com limas de conicidade 0.02 número 50 acionado pelo sitema Pow-R apresentou resultados, significantemente, superior ao sistema ProFile 0.04 número 35 em reduzir a quantidade de bactérias no terço apical.

WEIGER; ELAYOUTI; LÖST ${ }^{145}, 2002$ desenvolveram um estudo para determinar a eficiência do preparo biomecânico com instrumentação manual e rotatória em canais ovais. Para tanto, os autores utilizaram 75 canais ovais, igualmente, divididos em 3 grupos. O terço apical foi preparado com o sistema LightSpeed até o calibre 52,2 (incisivos inferiores) e 57,5 (raiz distal de molares inferior). O terço médio foi preparado com limas tipo Hedströen manuais com movimentos circulares, com o sistema Hero conicidade 0,06 e com o sistema LightSpeed. Os dentes foram divididos em terços, cervical, médio e apical, e submetidos as análises de comparações antes e após instrumentação. Após análise dos resultados os autores relataram que a instrumentação com as limas Hedströen removeram e tocaram em mais parede dentinária que os sistemas rotatórios Hero e LightSpeed, no entanto, não houve diferenças significantes na remoção dentinária entre as limas Hedströen e Hero e, finalizam, recomendando que novos instrumentos com novos modelos, formas e desenhos sejam introduzidos no mercado para instrumentação de canais ovais. 
ZELADA et al. ${ }^{155}, 2002$ analisaram o efeito da velocidade de rotação e de curvaturas radiculares durante o uso de sistemas rotatório ProFile para preparo dos canais radiculares. Foram utilizados 120 canais radiculares de molares extraídos, que foram divididos em dois grupos de acordo com a curvatura, maior ou menor que 30 graus. Foram estabelecidas três diferentes velocidades de rotação: 150, 250 e 350 rpm para instrumentação dos canais. Com os resultados obtidos os autores concluíram que a velocidade quanto mais alta e a curvatura quanto maior representam fatores importantes para fratura dos instrumentos, e finalizam relatando que o mais importante está associado a curvatura dos canais.

PATAKY et al. ${ }^{101}, 2002$ compararam a eficácia antimicrobiana de diferentes técnicas de preparo do canal radicular em 40 pré-molares superior. Os canais foram infectados com cepas de Enterococcus faecalis. Os dentes foram divididos em 5 grupos: G 1 - instrumentação com limas tipo K de aço inoxidável, G 2 - instrumentação com limas tipo K de níqueltitânio, G 3 - instrumentação com alargadores, G 4 - somente irrigação e G 5 - nenhum procedimento foi realizado. Sendo a técnica de instrumentação a escalonada progressiva (Step Back) e a substância irrigante foi solução salina com volume constante para todos os grupos. A análise estatística dos resultados mostrou que o G 5 não apresentou nenhuma redução da população bacteriana, o G 4 apresentou redução na população bacteriana, com relação ao $\mathrm{G} 5$, em todos os grupos instrumentados (G 1, G 2 e G 3) houve redução considerável na população bacteriana, inclusive com diferença estatística, quando comparado aos Grupo 4 e 5, no entanto, sem diferenças estatísticas entre si.

A capacidade de modelagem e limpeza de canais radiculares com achatamento mésio-distal foi analisada por BARBIZAM et al. ${ }^{16}, 2002$ através de estudo morfométrico. Vinte incisivos inferiores foram divididos em dois grupos de dez dentes cada: G 1 - Instrumentação coroa-ápice com os sistema rotatório ProFile 0.04 e G 2 - Instrumentação coroa-ápice 
com limas tipo $\mathrm{K}$ manual. A solução química auxiliar foi água destilada e deionizada, em volume igual para ambas técnicas. Após a instrumentação os dentes foram analisados histologicamente, em microscópio ótico acoplado a um computador que capturou as imagens e analisou as áreas com presença de restos orgânicos. A análise estatística mostrou diferença significante, ao nível de 1\%, entre as técnicas, sendo que a técnica manual apresentou melhor eficiência na limpeza do que a técnica rotatória, no entanto, nenhuma técnica apresentou paredes radiculares completamente isentas de restos orgânicos.

SCHÄFER; LOHMAN ${ }^{117}$, 2002 analisaram a eficácia do sistema rotatório FlexMaster comparado a instrumentação manual com limas tipo K Flexofile na capacidade de preparar e manter a forma do canal radicular em blocos de resina, previamente, angulados em 28 e 35 graus de curvaturas. Para tanto foram utilizados 96 canais de resina calibrados a espessura equivalente à lima tipo $\mathrm{K} 15$, com comprimento real de trabalho de $13 \mathrm{~mm}$, que foram divididos em dois grupos com 48 canais cada, com dois subgrupos de 24 canais com angulação de 28 graus e 24 canais com angulação de 35 graus. Grupo A - FlexMaster, rotação constante de 250 rpm, torque de $2 \mathrm{~N}$, montado em peça de mão redução 8:1. Grupo B Limas de aço inoxidável tipo K FlexoFile. Após instrumentação e comparação dos resultados os autores puderam concluir que o sistema FlexMaster foi mais rápido no preparo do canal e com menor alteração na trajetória do canal do que a FlexoFile, no entanto, houve duas fraturas com as limas FlexMaster.

BARATO FILHO ${ }^{14}$,2002 estudou in vitro a capacidade de limpeza do canal radicular, em dentes que apresentavam achatamento da raiz, utilizando instrumentação rotatória associada a diferentes concentrações de hipoclorito de sódio. Observou que nenhuma das soluções estudadas possibilitou canais radiculares isentos de detritos, no entanto, a mais eficaz foi a solução de hipoclorito de sódio $5 \%$, seguido do hipoclorito a 1 e $0,5 \%$. 
WALTERS; BAUMGARTNER; MARSHALL ${ }^{143}$, 2002 realizaram um trabalho com o intuito de avaliar a eficácia da irrigação realizada com sistema rotatório (Quantec-E com sistema de irrigação, Analytic comparado ao método manual, seringa e agulha, no terço apical dos canais radiculares. Foram utilizados vinte pares combinados (bilateral) de dentes unirradiculares, que foram divididos em dois grupos Grupo A e B com dez dentes cada, sendo que a única variação foi o método de irrigação. Também foi realizado secções a 1, 3 e $5 \mathrm{~mm}$ na região apical no comprimento de trabalho, com o intuito de verificar a eficiência em diferentes níveis deste terço. A porcentagem de debris e de smear layer foi anotada e levada aos testes estatísticos. O grupo A (irrigação seringa agulha) apresentou maior quantidade de debris e smear layer ao nível de $1 \mathrm{~mm}$ do que aos 3 ou $5 \mathrm{~mm}$. No grupo B (irrigação rotatória) não houve diferenças, significantes, entre os níveis (1, 3 e $5 \mathrm{~mm}$ ). Entre os grupos ( $A$ e B) não houve diferença quanto a capacidade de limpeza (remoção) de debris e smear layer, no entanto, o sistema Quantec-E mostrou-se mais veloz e com um volume de líquido maior do que o manual (seringa agulha).

MAYER; PETERS; BARBAKOW ${ }^{89}$, 2002 avaliaram a presença de smear layer após a instrumentação com dois tipos de sistema rotatório: ProFile 0.04 e Lightspeed associados ou não ao uso do ultra-som variando-se $\mathrm{a}$, ainda, a ponta do ultra-som entre uma lima tipo $\mathrm{K}$ de aço inoxidável e uma ponta (haste) lisa de níquel titânio irrigados com $2 \mathrm{~mL}$ de hipoclorito de sódio 5,25\% alternado com EDTA a 17\% em microscopia eletrônica de varredura com aumento de 15x, 200x e 400x. Para tanto os autores utilizaram 42 dentes unirradiculares com um único canal divididos em 6 grupos, a saber: Grupo 1 - instrumentação com o ProFile sem uso do Ultra-som (controle); Grupo 2 - Instrumentação com o ProFile associado com agitação do Ultra-som montado com lima tipo K; Grupo 3 Instrumentação com o ProFile associado com agitação do Ultra-som montado com a haste lisa em níquel titânio; Grupo 4- Instrumentação com o Lightspeed sem uso do Ultra-som (controle); Grupo 5 - Instrumentação 
com o Lightspeed associado ao Ultra-som montado em lima tipo K; Grupo 6- Instrumentação com o Lightspeed associado ao Ultra-som montado em haste lisa em níquel titânio, onde o tempo de agitação ultra-sônica ficou estabelecido em 1 minuto. Após leitura dos resultados os autores concluíram que: a agitação ultra-sônica não reduziu a camada de smear layer durante o preparo do canal radicular e que a forma do desenho do instrumento utilizado no Ultra-som (lima tipo $\mathrm{K}$ ou haste lisa) não influenciou melhor capacidade de limpeza, por fim que não houve diferenças estatísticas entre os grupos instrumentados com o sistema ProFile 0.04 e o Lightspeed.

AMARAL et al. ${ }^{6}, 2003$ avaliaram a capacidade de corte de limas tipo $\mathrm{K}$ de aço inoxidável e de níquel titânio em placas de osso. Para tanto foram utilizadas limas endodônticas tipo K (Maillefer) em comprimentos de 21 e 25 mm, número 35, em dois tipos de liga metálica: aço inoxidável (Flexofile) e níquel titânio (Nitiflex), sendo 12 limas de cada grupo, em m total de 48 instrumentos. Após análise dos resultados os autores puderam concluir que: as limas endodônticas de níquel titânio (NiTiflex) apresentaram maior capacidade de corte do que as limas endodônticas de aço inoxidável (Flexofile), o comprimento do instrumento não interferiu sobre sua capacidade de corte e que as limas de níquel titânio e as limas de aço inoxidável (Flexofile) perderam o corte com o uso, sendo que essa perda mais significante do primeiro para o segundo uso.

GONÇALVES; BROSCO; BRAMANTE ${ }^{62}$, 2003 avaliaram a limpeza de canais achatados instrumentados com três diferentes técnicas. Para tanto, foram selecionados trinta incisivos inferiores, onde a abertura coronária foi realizada e, posteriormente, os canais foram preenchidos com tinta nanquim, previamente acondicionados em tubetes anestésicos, sendo a mesma levada ao interior do canal radicular com auxílio de uma seringa Carpule e uma agulha para anestesia. Após 48 horas, tempo esperado para que o corante secasse no canal, os dentes foram divididos em três grupos: G1 - instrumentação rotatória com o sistema Great Taper (GT Tulsa Dental); G2 - instrumentação manual com limas tipo K 
(Maillefer Instruments - Ballaigues - Suíça) e G3 - associação de ambas (mista). Após a instrumentação os dentes foram seccionados, longitudinalmente, e realizada a avaliação da limpeza dos canais radiculares através da visualização da remoção de corante nos terços cervical, médio e apical, ou seja, pontos sem corante indicando que houve toque do instrumento. Os resultados demonstraram que não houve diferença estaticamente significante na limpeza do canal entre as três técnicas de instrumentação estudadas, nos três terços avaliados.

BERGMANS et al. ${ }^{24}, 2003$ avaliaram a influência do desenho de limas com aumento progressivo da conicidade (ProTaper) e de conicidade constante (sistema $\mathrm{K}^{3}$ ), sendo ambos sistemas rotatórios de instrumentação. Para tanto, foram utilizados dez molares inferiores com curvaturas semelhantes. Os dentes foram escaneados com o aparelho Microfocos CT Scanner (SkyScan 1072, SkyScan b.v.b.a, Aartselaar, Belgium), antes e após a instrumentação, usando 80,0 Kv, $100 \mu \mathrm{A}$, a 1,0 mm de filtro de alumínio e 19x de magnificação resultando num total de 12,5 $\mu \mathrm{m}$. As raízes mesiais (vestibular e lingual) foram sorteadas e instrumentadas com os dois sistemas em questão. Após análise dos resultados e observações estatísticas os autores puderam relatar que os sistema ProTaper apresentou leve tendência a preservar a curvatura do canal radicular sem influenciar na trajetória, sendo que atenção especial deve ser dado na região cervical próximo a furca, entretanto não houve diferenças estatísticas significante entre os grupos testados. E os autores findam recomendando mais estudos com a finalidade de se observar eficiência na capacidade de limpeza, resistência à deformação e/ou fratura e tempo requerido para a instrumentação.

PETERS et al. ${ }^{103}, 2003$ realizaram um estudo in vitro com o intuito de avaliar a performance final, no preparo de canais de molares superiores, com o sistema rotatório de níquel titânio ProTaper empregando-se a Micro Tomografia Computadorizada ( $\mu \mathrm{CT}$ ) numa resolução de $36 \mu \mathrm{m}$. Os canais foram tridimensionalmente reconstruídos e avaliados pelo volume, superfície da área, diâmetro instrumentado, 
trajetória original do canal e preparo final da superfície. Em função do volume dos canais mésiovestibular (mv), distovestibular (dv) e palatino (p), dividiu-se os mesmos em largos e atrésicos. Após análise dos resultados os autores puderam relatar que o volume e a área aumentaram significante e similarmente entre os canais mv, dv e p. Sobre a trajetória do canal leve tendência ao desvio independente do canal instrumentado e, por fim, que o sistema apresentou condições mais propícias para a instrumentação de canais atrésicos.

SANTOS; SANTOS ${ }^{115}$, 2003 realizaram um estudo com o intuito de verificar a eficiência de corte das limas rotatórias $K^{3}{ }^{3}$ conicidade 0.04 e 0.06 comprimento de $30 \mathrm{~mm}$, avaliando a perda de massa dentinária pelo método da dupla pesagem comparando a instrumentação de Oregon modificada e escalonada dinâmica. Para tanto foram selecionados 40 se utilizou as raízes distais de molares inferiores permanentes humanos extraídos. As raízes foram pesadas em balança analítica de precisão antes da instrumentação, sendo posteriormente, instrumentadas segundo os grupos: G-1 instrumentação através de Oregon modificada com os instrumentos $K^{3} \circledR$ conicidade 0.04 associadas a utilização de brocas Gates Glidden 2, 3 e 4; G-2 instrumentação escalonada utilizando os instrumentos com conicidade 0.06 associadas a utilização das brocas Gates Glidden 2 e 3. Ao final os autores concluíram que o grupo 1 apresentou uma perda de massa dentinária, significantemente, maior que no grupo 2, sendo que os autores discutem que tal resultado esteja ligado ao fato que de instrumentos de aço inoxidável permitem um maior desgaste dentinário devido a sua maior rigidez, conseqüentemente, maior poder de corte que os instrumentos de níquel titânio acionados a motor.

CALBERSON et al. ${ }^{27}, 2004$ avaliaram a habilidade de instrumentação (modelagem) do canal radicular do sistema rotatório de níquel-titânio ProTaper® em canais simulados em blocos de resina. Quarenta canais simulados em blocos de resina com 2 diferentes angulações 20 e 40 graus e áreas de estreitamento em duas diferentes posições anatômicas, a 8 e a 12 mm do terço coronário, foram 
instrumentados segundo recomendações do fabricante. Os resultados mostraram que dez instrumentos deformaram-se (oito instrumento F3 e dois S1, sendo que um instrumento S1 fraturou no grupo de $8 \mathrm{~mm}$ e 40 graus de curvatura). Assim, os autores concluem que o sistema rotatório de níquel-titânio ProTaper ${ }^{\circledR}$ apresentaram-se satisfatório para o preparo de canais atrésicos e curvos, no entanto, cuidados adicionais devem existir frente as limas F2 e F3, com o intuito de se evitar alterações no trajeto original do canal e, possíveis, fraturas.

FOSCHI et al. ${ }^{51}, 2004$ analisaram com auxílio de microscopia eletrônica de varredura (2000x) as paredes do dentinárias do canal radicular após instrumentação com o sistema rotatório ProTaper ${ }^{\circledR}$. A solução auxiliar da instrumentação foi hipoclorito de sódio 5\% associado com peróxido de hidrogenia a 3\% irrigação final com EDTA 17\%. Os resultados permitiram os autores concluírem que o sistema ProTaper ${ }^{\circledR}$ produziu superfícies dentinárias isentas de debris nos terços cervical e médio, mas foi ineficiente no terço apical para remover a smear layer e os debris, deixando inclusive áreas não tocadas pelos instrumentos.

SCHÄFER; VLASSIS ${ }^{120}$, 2004 curiosos em saber os resultados após a instrumentação dos canais radiculares com o sistema ProTaper ${ }^{\circledR}$ e $\mathrm{RaCe} \otimes$ em dentes naturais com curvaturas de 25 e 35 graus realizaram um estudo com 48 dentes molares humanos com as selecionados segundo a proposta da metodologia. Durante a instrumentação a solução auxiliar foi hipoclorito de sódio a 2,5\%, sendo que, após a clivagem longitudinal dos dentes os autores, também, analisaram a presença de debris e da smear layer. Os resultados mostraram que duas limas do sistema ProTaper ${ }^{\circledR}$ e três do $\mathrm{RaCe}{ }^{\circledR}$ fraturaram, quanto a capacidade de limpeza não foi verificado paredes dos canais isentas de resíduos, no entanto, quanto a capacidade de remoção dos debris o sistema RaCe ${ }^{\circledR}$ apresentou melhores resultados estatísticos que o ProTaper $®$. Entretanto, quanto à presença da smear layer não houve diferenças. $\mathrm{O} R \mathrm{RaCe} \circledast$ preservou o trajeto original do canal em condições melhores do que o ProTaper®, por fim, não houve diferenças quanto ao tempo de trabalho 
de cada sistema. Logo, dentro das condições estudadas, o sistema $\mathrm{RaCe}{ }^{\circledR}$ apresentou melhores resultados quanto a limpeza e respeito a curvatura original dos canais frente ao sistema ProTaper®.

PRATI et al. ${ }^{106}$, 2004 analisaram in vitro com auxílio da MEV, aumento de 2000x, a aparência das paredes dos canais radiculares após instrumentação com três diferentes sistemas rotatórios de níquel-titânio e uma técnica manual. Quatro diferentes instrumentos foram utilizados: $\mathrm{K}^{3} \AA$, Hero $642 \AA, \mathrm{RaCe} \circledast$ e limas tipo K. Cada amostra foi irrigada com 5 $\mathrm{mL}$ de hipoclorito de sódio $5 \%$ e $5 \mathrm{~mL}$ de peróxido de hidrogênio 3\% e RcPrep (1 mL). As amostras foram analisadas nos três terços comparandose o aspecto visual com uma escala pré-definida, com diferentes parâmetros: presença do smear layer, debris e superfície atingida pelos instrumentos. Após análise dos resultados os autores concluíram que o terço apical mostrou, significantemente, mais debris, smear layer e superfície irregulares de ação dos instrumentos. Não houve diferença entre os terços: coronário, médio e apical, frente aos métodos rotatória e manual, quanto aos quesitos debris, smear layer e a ação dos instrumentos na parede dentinária. Maiores quantidades de debris foram encontrados no terço apical para o sistema $K^{3} \circledR$ e $\mathrm{RaCe} \circledast$ quando comparados com o Hero $642 \AA$ e limas tipo $K$. Conseqüentemente, concluem que sistema mecânico, com limas de níquel-titânio, produzem resultados similares a instrumentação manual convencional usando limas do tipo K. O estudo também, demonstrou, que os resultados foram influenciados pela morfologia dos instrumentos e, que, o terço apical caracterizou-se por apresentar grande quantidades de debris e smear layer.

PAQUÉ; MUNSCH; HÜLSMANN ${ }^{97}, 2005$ compararam o preparo do canal radicular usando o sistema $\mathrm{RaCe} \AA$ e o ProTaper ${ }^{\circledR}$. Para tanto os autores utilizaram 50 raízes mesiais de molares inferiores, com a curvatura variando de 20 a 40 graus. Todos os canais foram preparados até o instrumento de calibre 30 e irrigados com $2 \mathrm{~mL}$ de solução de hipoclorito de sódio 3\% entre cada instrumento. Os autores, após análise 
dos resultados, concluíram que os dois sistemas preservaram a curvatura do canal radicular, ambos grupos apresentaram 50\% de casos de instrumentação irregular no canal, quanto à presença de debris não houve diferenças estatísticas entre os terços e entre os sistemas rotatórios, frente à presença da smear layer não houve diferenças estatística entre os terços coronário e cervical, entretanto, o sistema RaCe ${ }^{\circledR}$ apresentou melhores resultados no terço apical, ambos sistemas alteraram o comprimento real de trabalho original, sendo que o sistema ProTaper ${ }^{\circledR}$ apresentou um caso de fratura de instrumento e, por fim, que o sistema ProTaper ${ }^{\circ}(90,9$ s) foi, estatisticamente, mais rápido que o $\operatorname{RaCe}(137,6$ s), no entando, quanto ao quesito limpeza os autores findam que ambos sistemas são insatisfatórios.

SILVA; KOBAYASHI; SUDA ${ }^{125}$, 2005 analisaram a influência do torque e pressão vertical durante a instrumentação com os sistemas rotatórios $\mathrm{RaCe} \AA$ e ProFile ${ }^{\circledR}$. Para tanto, foram utilizados 30 incisivos (central e lateral, superior e inferior) com raízes de $12 \mathrm{~mm}$ como CRT, divididos em 3 grupos: $\mathrm{G} 1$ - Sistema $\mathrm{RaCe}{ }^{\circledR}$ conicidade 0.02 técnica ápice-coroa, G 2 - sistema $\mathrm{RaCe}{ }^{\circledR}$ conicidade 0.04 técnica ápice-coroa e G 3 - sistema ProFile $\AA$. Dois dispositivos sensoriais foram acoplados e conectados num ociloscópio digital, controlando e analisando os valores do torque e pressão vertical. Após análise dos resultados os autores observaram que o sistema $\mathrm{RaCe}{ }^{\circledR}$ apresentou valores menores de torque, com diferenças estatisticamente significante, quando comparados ao grupo do ProFile ${ }^{\circledR}$, no entanto, sem diferença entre si. Quanto a pressão vertical houve diferença estatística do grupo 1 para 03 e do 2 para 03 , sendo que os valores mais altos foram frente ao primeiro instrumento utilizado e o grupo do ProFile ${ }^{\circledR}$ apresentou valores mais altos, seguido pelo $\mathrm{RaCe} \circledast 0.04$ 
É objetivo deste estudo foi investigar, com auxílio da microscopia eletrônica de varredura, os itens a saber:

1. A eficiência das soluções auxiliares da instrumentação a base de gluconato de clorexidina $0,12 \%$ e solução aquosa de hipoclorito de sódio a 1\% quando utilizadas na irrigação dos canais radiculares e associadas à instrumentação dos canais,

2. A eficiência de ação das técnicas do preparo biomecânico manual com limas tipo $\mathrm{K}$ Flexofile e os sistemas rotatórios $\mathrm{K}^{3 \circledR}, \mathrm{RaCe}^{\circledR}$ e ProTaper ${ }^{\circledR}$,

3. Os efeitos desses dois fatores anteriores nos terços médio e apical dos canais radiculares de dentes com achatamento proximal. 
Foram selecionados, dentro de um grupo de dentes, 95 incisivos centrais e laterais inferiores com raízes completamente formadas, unirradiculados, semelhantes morfologicamente, com ausência de fraturas, calcificações e dilacerações. Os dentes foram radiografados, em filmes oclusais, no sentido mésio - distal excluindo-se aqueles que apresentavam mais de um canal, calcificações ou nódulos. Os comprimentos dos dentes variaram entre 19 e 23 milímetros, confirmados por meio de um paquímetro digital.

O projeto, inicialmente, foi entregue no dia 23 de março de 2004 protocolo de recebimento 41/2004 - para apreciação do Comitê de Ética em Pesquisa em Seres Humanos, sendo aprovado no dia 28 de abril de 2004 (Apêndice 1, 2 e 3).

Os dentes foram mantidos, até o momento de uso, em solução de formol a $10 \%$, em geladeira a temperatura de $9^{\circ} \mathrm{C}$ com a finalidade de mantê-los hidratados $\mathrm{e}$ isentos de proliferação bacteriana ${ }^{95}$. Na seqüência, eles foram lavados em água corrente por uma hora, com o intuito de eliminar possíveis resíduos da solução de formol sendo, posteriormente, secos com jato de ar e com gaze. Após a abertura coronária, foram separados 15 dentes, sendo divididos em três grupos, com cinco dentes em cada grupo, onde o primeiro e o segundo foram instrumentados manualmente com limas tipo K (Flexofile, Maillefer, Suíça), variando-se a solução irrigante, EDTA 17\% para o primeiro e água destilada para o segundo; o terceiro grupo não recebeu qualquer tipo de procedimento. Esses dentes serviram de parâmetros visuais das condições das paredes dos canais radiculares frente aos demais grupos.

Os oitenta dentes restantes foram distribuídos em quatro grupos experimentais em função das técnicas de instrumentação, a saber: manual-macânica (limas tipo K e brocas de Gates Glidden - Maillefer) e rotatória com o sistema ProTaper ${ }^{\circledR}$ (Maillefer), RaCe ${ }^{\circledR}$ (FKG Dentaire) e $\mathrm{K}^{3} \circledR$ (Sybron Kerr). Esses grupos foram divididos em dois subgrupos, agora em função da solução química auxiliar, Gluconato de Clorexidina a 
0,12\% e Hipoclorito de sódio a 1\% (PHARMACIA SPECIFICA LTDABauru/SP), conforme Tabela I.

Os dados referentes ao comprimento de trabalho (CT), solução irrigadora (Gluconato de Clorexidina a $0,12 \%$ e solução aquosa de Hipoclorito de sódio a 1\%, técnica de instrumentação, e número de uso do instrumento foram anotados em ficha individuais.

Tabela 1 - Distribuição dos dentes dentro dos grupos experimentais

\begin{tabular}{cccc}
\hline & \multicolumn{3}{c}{ Solução química auxiliar da irrigação } \\
\cline { 2 - 4 } Técnicas de & Clorexidina & Hipoclorito de Sódio & Total \\
instrumentação & $0,12 \%$ & $1 \%$ & 20 \\
\hline Manual & 10 & 10 & 20 \\
ProTaper ${ }^{\circledR}$ & 10 & 10 & 20 \\
RaCe ${ }^{\circledR}$ & 10 & 10 & 20 \\
$\mathrm{~K}^{3} \circledR$ & 10 & 10 & 80 \\
\hline Total & 40 & 40 &
\end{tabular}

O acesso à câmara pulpar e ao canal radicular foi realizado de acordo com os princípios propostos por SOARES; GOLDBERG ${ }^{130}, 2001$.

O canal radicular foi explorado em toda a sua extensão com instrumento manual de diâmetro compatível ao diâmetro anatômico do canal que não era superior ao diâmetro de uma lima tipo K número 15. Esta exploração permitiu determinar o comprimento do dente (CRD) em relação à abertura do forame apical e sua extensão foi estabelecida quando a extremidade do instrumento fosse vista (com auxílio de uma lupa de 10x) cerce ao forame. O limitador de penetração era então deslizado até tocar a borda incisal do dente e o instrumento removido do canal e a distância da ponta do instrumento ao limitador foi medida e anotada. O comprimento de trabalho (CT) foi obtido subtraindo-se 1,0 mm do CRD.

O ápice foi coberto com uma bolinha de cera utilidade (Herpo Produtos Dentários Ltda. Rio de Janeiro) e, posteriormente, por cola 
Araldite Ultra-Rápida (Giba Geigy S/A - Fabricado pela Brascola Ltda.) com o intuito de se evitar a extrusão da solução irrigadora.

Para a instrumentação dos canais foi confeccionada uma base cilíndrica de silicona de condensação (Optosil ${ }^{\circledR}$ e Optosil Xantopren ${ }^{\circledR}$ Heraeus Kulzer GmbH \& Co.KG-Alemanha), com auxílio de um cilindro plástico de dimensões (4 cm de altura por $3 \mathrm{~cm}$ de diâmetro) com um orifício ao centro. O conjunto (molde e dente) foi apoiado em uma bancada plana, durante todos os procedimentos de instrumentação, com o intuito de padronizar o ângulo dos dentes em questão.

\section{Instrumentação manual-mecânico}

A técnica utilizada para o preparo manual-mecânico do canal radicular foi a Técnica Mista Invertida, preconizada pela disciplina de Endodontia da UNESP-Araçatuba ${ }^{73}$, conforme descrição: preparo do terço coronário com ampliadores de orifício do tipo Auerback 1, 2 e 3 (Maillefer - Suíça) alternado com irrigação / aspiração / inundação; preparo do terço médio realizado com o emprego da brocas Gates Glidden (Maillefer - Suíça), na seqüência, 3, 2 e 1 (alternado com irrigação / aspiração / inundação); preparo do terço apical com auxílio de limas tipo K 15 (FlexoFile, Maillefer - Suíça ) até a lima 35; acabamento final, realizado com limas tipo K (FlexoFile, Maillefer - Suíça ), calibres superiores ao 35, e manobras semelhantes (limagem) a fase anterior, efetuando-se o preparo ápice coroa de forma anatômica e renovação freqüente da solução irrigadora entre os instrumentos.

Como resultado final, foram utilizados $10 \mathrm{~mL}$ da solução testada por dente instrumentado, em temperatura ambiente $23{ }^{\circ} \mathrm{C}\left(+2 /-2{ }^{\circ} \mathrm{C}\right)$.

O canal radicular foi aspirado e seco com pontas de papel absorvente estéril. Neste grupo, a exemplo dos seguintes foram utilizados 2 caixas novas de instrumentos para cada solução envolvida. 


\section{Instrumentação rotatória}

Para a realização da instrumentação rotatória foi utilizado o micromotor elétrico Endo Plus (VK Driller Equipamentos Elétricos Ltda., São Paulo, Brasil), ajustado a uma velocidade de 300 rpm no sentido horário e torque ajustado em $2 \mathrm{~N} / \mathrm{cm}$. Foram empregados instrumentos de níquel - titânio de três sistemas distintos: sistema ProTaper ${ }^{\circledR}$, sistema RaCe ${ }^{\circ}$ e sistema $\mathrm{K}^{3} \circledast$ (Figuras 1, 2 e 3).

\section{Sistema ProTaper ${ }^{\circledR}$ (Figura 1)}

A seqüência utilizada foi modificada, frente à recomendada pelo fabricante. O primeiro instrumento utilizado foi o S1, até o limite de 2/3 do canal radicular, o segundo instrumento, foi o SX atuando, principalmente, no terço cervical finalizando essa etapa com o instrumento S2. Finda a etapa de preparo do terço cervical e médio, passou-se à instrumentação do terço apical, com os instrumentos F1, F2 e F3 até o comprimento real de trabalho.

Durante o preparo efetuou-se a irrigação com as soluções em teste perfazendo um total de $10 \mathrm{~mL}$ da solução por dente, em temperatura ambiente $23{ }^{\circ} \mathrm{C}\left(+2 /-2{ }^{\circ} \mathrm{C}\right)$. 


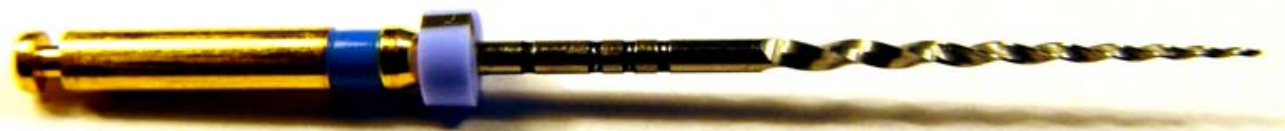

Figura 1.1 - Instrumento F3
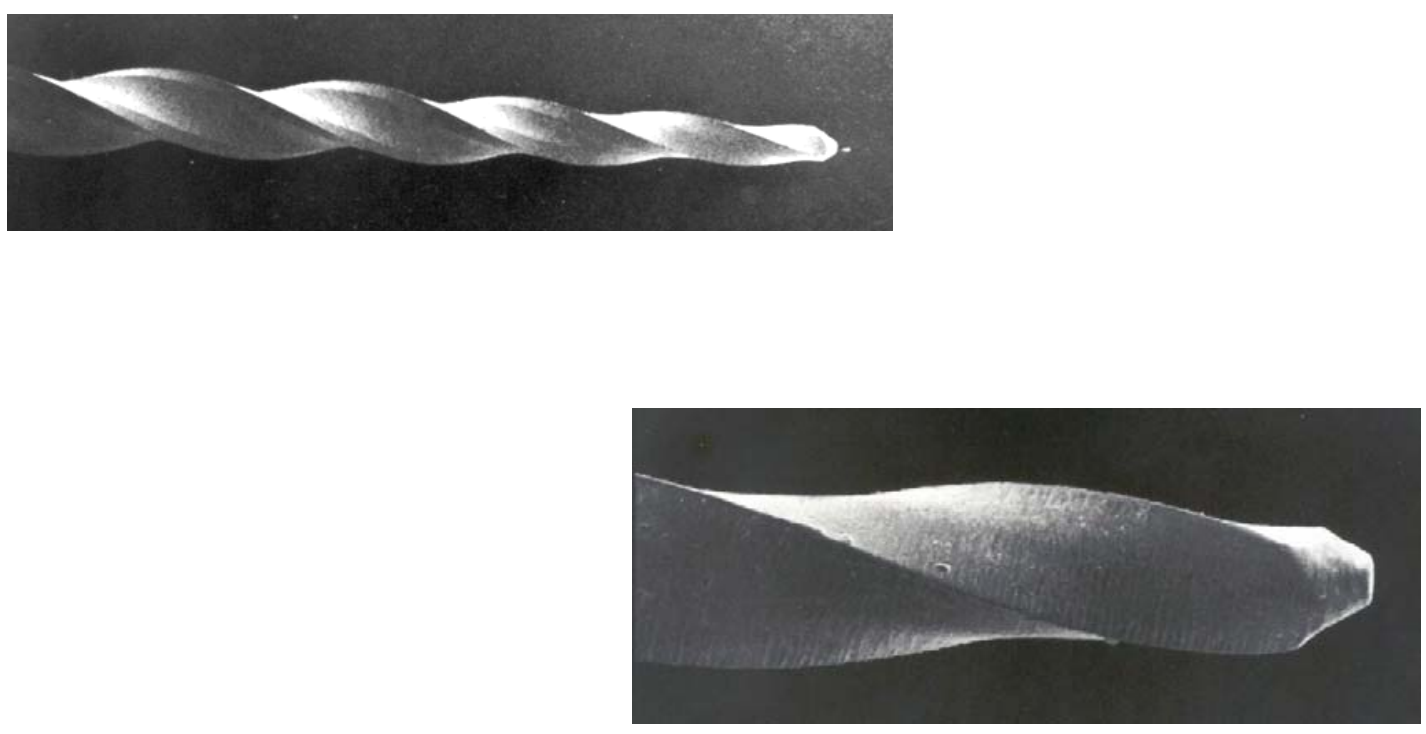

Figura 1.2 - Fotomicroscopia da parte ativa do instrumento F3 (15x) e detalhe da extremidade (100x)

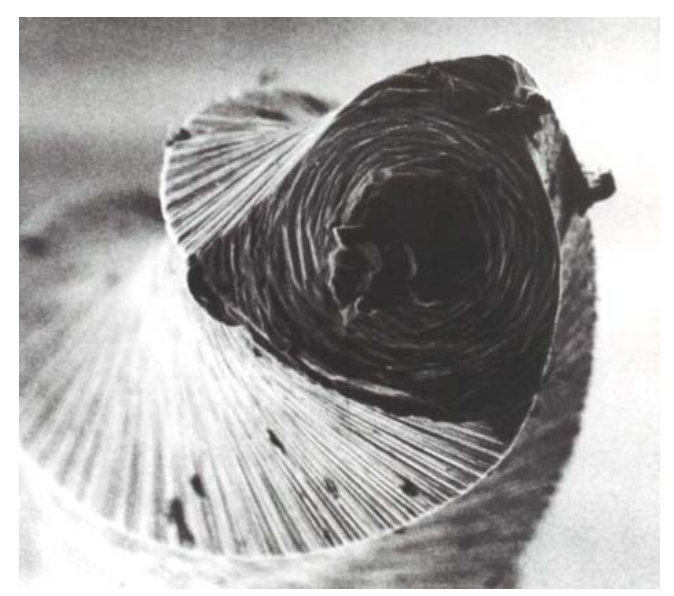

Figura 1.3 - Fotomicroscopia (200x) da ponta do instrumento F3

Figura 1 - ProTaper ${ }^{\circledR}$ 


\section{Sistema RaCe ${ }^{\circledR}$ (Figura 2)}

Neste grupo, a exemplo do anterior, seguiu-se as especificações e recomendações do fabricante, dividindo-se o preparo com os instrumentos pré-RaCe ${ }^{\circledR}$ e $\mathrm{RaCe}{ }^{\circledR}$. Os pré-RaCe ${ }^{\circledR}$ são instrumentos de conicidades maiores que trabalham apenas nos terços cervical e médio dos canais. O comprimento total é de $19 \mathrm{~mm}$ e a parte ativa tem $10 \mathrm{~mm}$. Os $\mathrm{RaCe}{ }^{\circledR}$ são instrumentos de calibres menores que atuam no CRT. A seqüência, coroa-ápice, foi iniciada com o instrumento, pré-RaCe ${ }^{\circledR}$, número 40 conicidade 0.10 seguido pelo instrumento, pré-RaCe $\AA, 35$ conicidade 0.08 , ambos atuando no terço cervical. Utilizou-se uma lima tipo $\mathrm{K}$ número 15 no $\mathrm{CRT}$, com intuito de exploração. A seguir iniciou-se o preparo com os instrumentos, $\mathrm{RaCe} \AA$, número 25 conicidade $0.02 ; 25$ conicidade 0.04 e 25 conicidade 0.06 no CRT. Entre o uso de cada instrumento, sempre houve irrigação/aspiração/inundação com a solução auxiliar da instrumentação resultando, obrigatoriamente, num total de 10 $\mathrm{mL}$ da solução testada por dente.

\section{Sistema $K^{3}{ }^{\circledR}$ (Figura 3)}

Inicialmente utilizou-se o instrumento (ampliador de orifício) calibre 25 conicidade 0.10 e o 25 conicidade 0.08 para o preparo do terço cervical e início do médio. Para o preparo do terço médio e início do apical, utilizou-se os instrumentos 40 conicidade 0.06 a dois terços do CT, seguido pelos de calibre 25, 30 e 35 conicidade fixa de 0.06 atuando no interior do canal radicular em seu CRT, sempre alternado com a solução auxiliar, num total de $10 \mathrm{~mL}$ da solução testada por dente. 


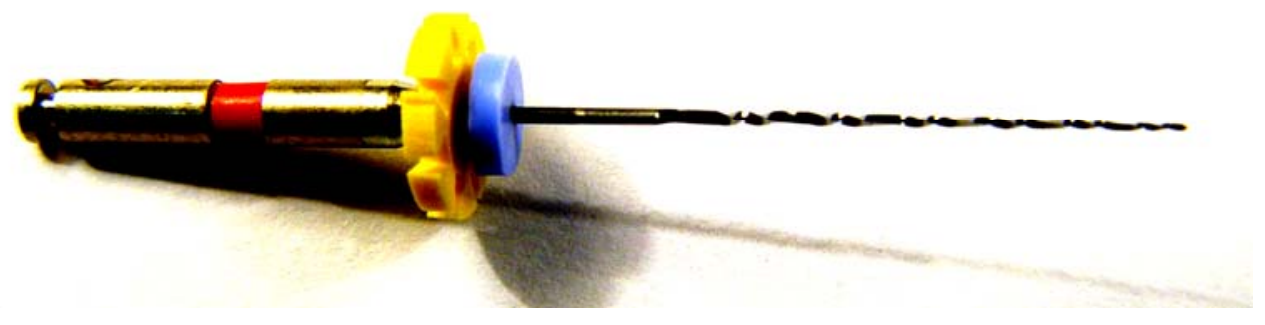

Figura 2.1 - Instrumento 25/0.02
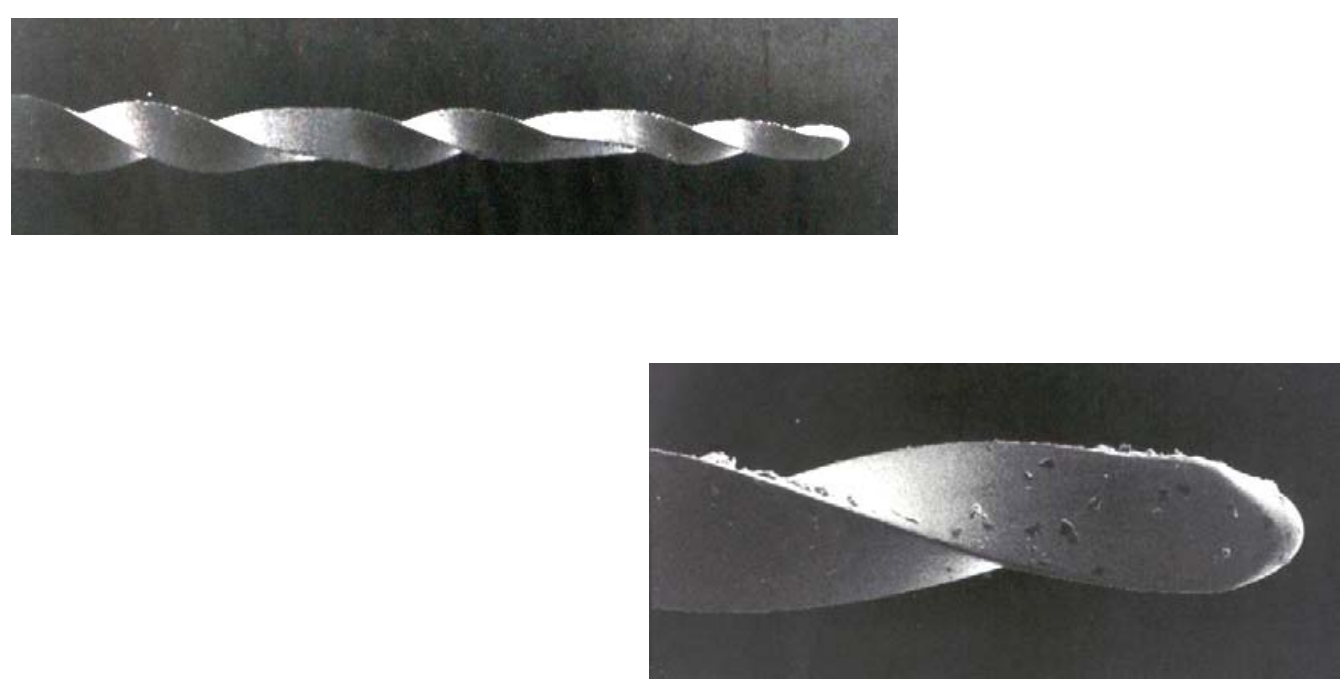

Figura 2.2 - Fotomicroscopia da parte ativa do instrumento 25/0.02 (15x) e detalhe da extremidade (100x)

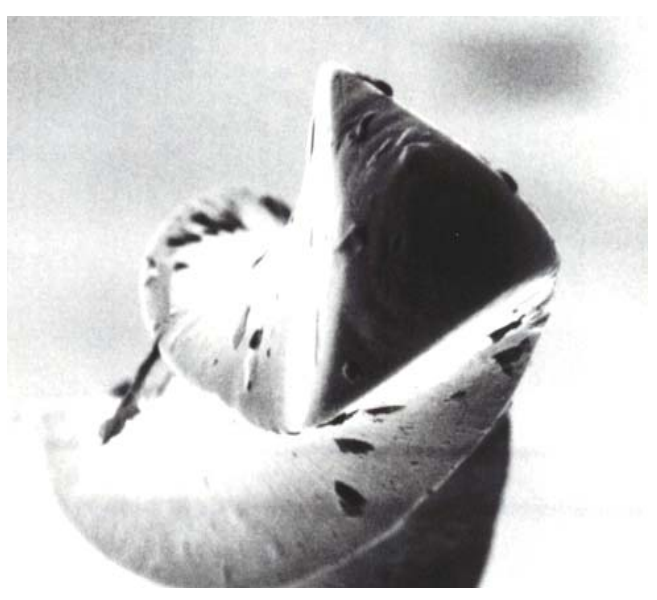

Figura 2.3 - Fotomicroscopia (200x) da ponta do instrumento 25/0.02 Figura 2 - $\mathrm{RaCe} \circledast$ 


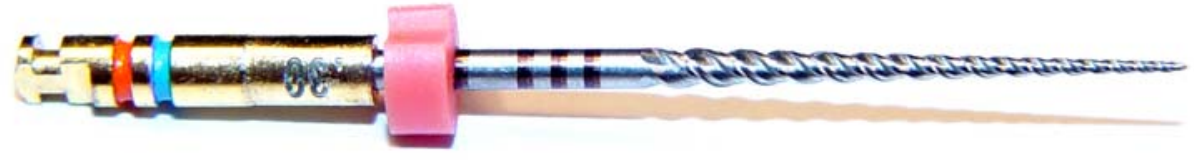

Figura 3.1 - Instrumento 30 conicidade 0.06

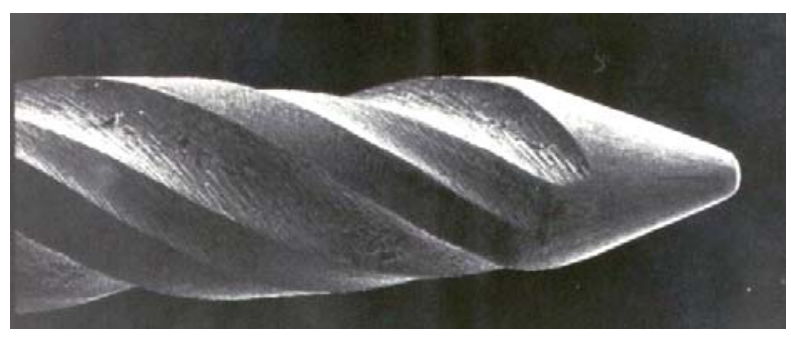

Figura 3.2 - Fotomicroscopia da parte ativa do instrumento 30/0.06 (15x) e detalhe da extremidade (100x)

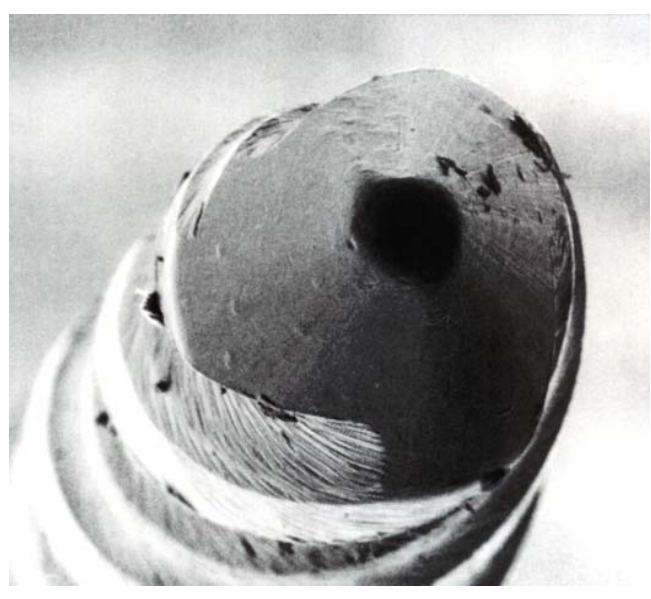

Figura 3.3 - Fotomicroscopia (200x) da ponta do instrumento 30/0,06 Figura $3-K^{3} \circledast$ 
As soluções auxiliares da instrumentação foram levadas ao canal com auxílio de seringas de vidro tipo Luer Lock, de $10 \mathrm{~mL}$ acopladas com agulhas hipodérmicas 30x3, encurvadas e destituídas de seu bisel. Essas soluções foram continuamente renovadas durante a instrumentação e entre a troca dos instrumentos de tal forma que no final havia sido utilizado um volume de $10 \mathrm{~mL}$ da solução testada por amostra dental.

Ao final do preparo biomecânico (instrumentação, irrigação, aspiração e inundação) os canais foram secos efetuando-se, inicialmente, a aspiração com pontas aspiradoras acopladas a bomba a vácuo (Dabi Atlante) e, posteriormente, com cones de papel absorvente (Dentsply Ind. e Com. Ltda - Petrópolis, RJ, Brasil). As câmaras pulpares foram seladas com cera utilidade (Herpo Produtos Dentários Ltda. Rio de Janeiro) com a finalidade de proteger o interior do canal radicular durante o corte longitudinal com as pontas diamantadas.

Com auxílio de pontas diamantadas esféricas 1012, foram confeccionados sulcos nas faces vestibular e lingual, sem penetrar no espaço do canal radicular. Com o auxílio de um canivete para gesso, especialmente, adaptado efetuou-se a clivagem dos dentes obtendo-se as hemi-secções radiculares, de modo a expor a luz do canal preparado. As amostras assim obtidas retornaram aos frascos numerados e, posteriormente, levadas a uma estufa em temperatura de $45^{\circ} \mathrm{C}$, por um período de 12 horas, com a finalidade da desidratação para favorecer 0 processo de metalização.

Cada hemi-parte da raiz foi fixada com esmalte incolor em uma pequena plataforma metálica circular, procedendo-se então a metalização. Utilizou-se o microscópio JSM P-15 (Jeol Scanning Microscope P-15 Jeol, Japan). Os corpos de prova foram analisados individualmente, sendo cada um deles colocado no tubo emissor de elétrons. Após as programações do microscópio, o feixe de elétrons foi dirigido para a superfície do corpo de prova a ser analisada, proporcionando uma imagem na câmara visual. Com o aparecimento da imagem projetada inicialmente com um aumento de 50x, localizou-se a 
superfície do corpo de prova e ampliou-se até 1000x (15 Kv) para a análise por varredura do campo e também para a tomada fotográfica (Máquina Fotográfica Mamya - Japan) com os filmes Film Fuji SS 120 Neopan ISO 100.

Assim, foram tomadas fotomicrografias mais representativas, escolhidas, uma do terço médio e outra do terço apical por amostra dental, totalizando 160 fotomicrografias ao final do experimento. Sendo que essas, fotomicrografias, foram processadas e ampliadas no tamanho $9 \times 12$.

Durante a observação e tomadas fotográficas, realizou-se a numeração de cada fotomicrografia, tanto do terço médio, quanto do apical, sendo as mesmas ordenadas de 1 a 160. Anotou-se, em folha de papel à parte, as informações pertinentes, sendo que no momento da análise o examinador estava impossibilitado de reconhecer o grupo e o subgrupo de cada fotomicrografia em questão (teste cego).

Aos três avaliadores, previamente calibrados, foram fornecidos um gabarito com 5 (cinco) fotomicrografias cada qual com um escore já préestabelecido. As fotomicrografias foram distribuídas em ordem decrescente a partir daquela que apresentava a superfície mais limpa para a menos limpa, atribuindo-lhes escores de 0 a $4^{95,105,132,136}$ considerando e observando os seguintes critérios (Figura 4):

Escore 0: Superfície completamente limpa, todos os túbulos estavam completamente visíveis ou com raras partículas dispersas.

Escore 1: Superfície, em que os túbulos dentinários estavam visíveis com partículas dispersas pela parede dentinária.

Escore 2: A luz dos túbulos apresentava coberta por uma fina camada de resíduos dentinários e raras partículas grosseiras na superfície.

Escore 3: Superfície recoberta por uma camada espessa de resíduos dentinários, com raros túbulos expostos.

Escore 4: Superfície totalmente coberta caracterizando a superfície com a maior presença de smear layer, inclusive com partículas maiores fragmentadas. 

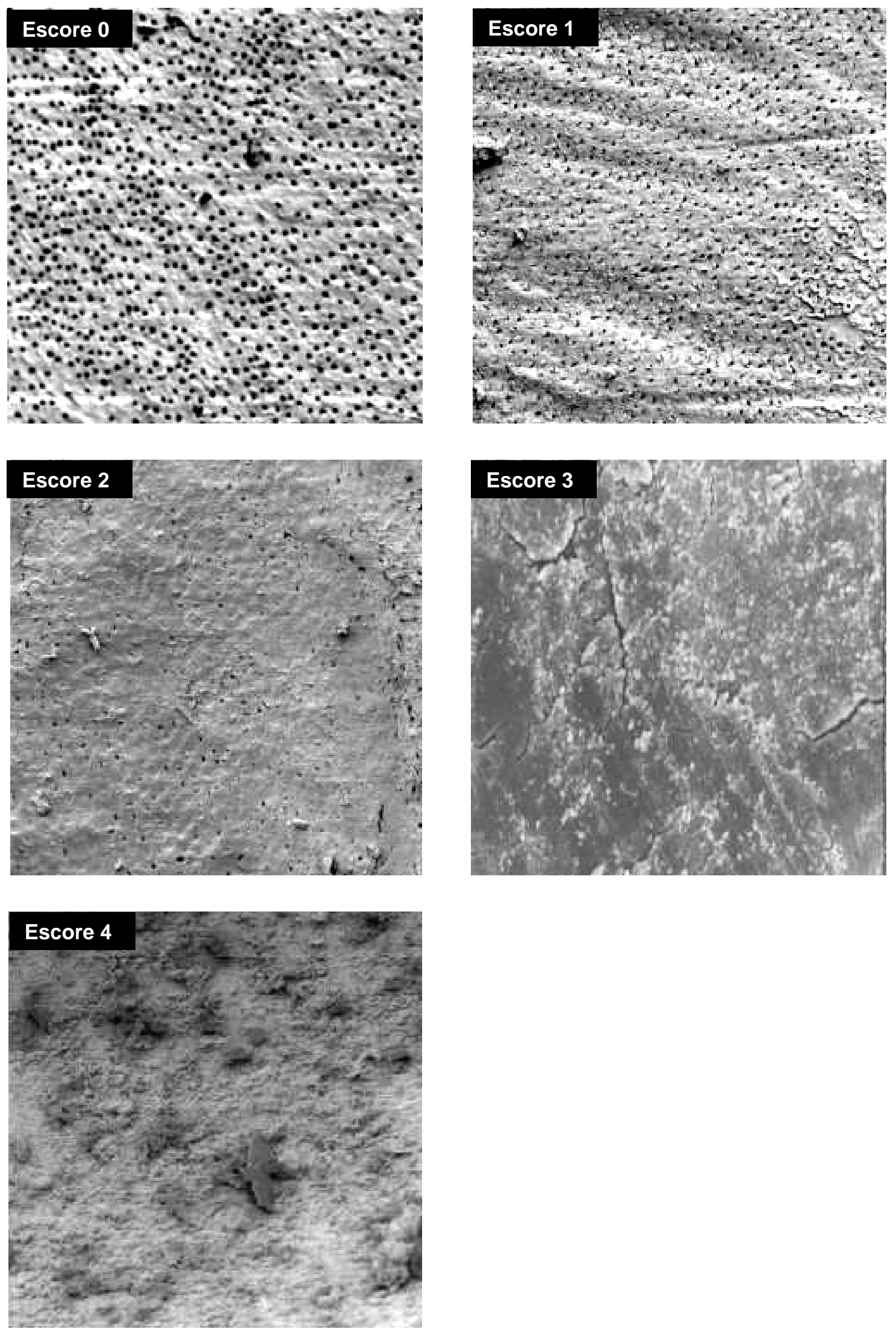

Figura 4- Fotomicrografias com os respectivos escores (0 a 4), o qual foram entregues aos examinadores (1000x $15 \mathrm{kV})$ 
Cada examinador observou e anotou os resultados referentes as fotomicrografias numa ficha específica constando de 160 linhas e duas colunas, contendo o número, de 1 a 160, referente ao espécime analisado e outra coluna em branco para anotação do escore atribuído pelo examinador (Anexos 1, 2 e 3)

Os valores referentes aos escores, escolhidos pelos examinadores, foram comparados entre si e somente os dois valores coincidentes foram levados à análise estatística (Anexo 4). Por exemplo, para a fotomicrografia número 2 o examinador 1 atribuiu escore 3, o examinador 2 atribuiu 4 e o examinador 3 atribuiu 4, o valor coincidente foi o escore 4, logo o valor 4 foi levado aos cálculos estatísticos. Os valores de leitura foram submetidos ao testes estatísticos não paramétrico, por se tratar de escores, com nível de significância de 5\%. Para tanto foram utilizados os testes estatísticos não paramétricos de Mann-Whitney, quando 2 (duas) amostras independentes e Kruskal-Wallis quando comparadas mais de 2 (duas) amostras independentes.

A hipótese verificada foi à quantidade de smear layer presente nas paredes radiculares, comparando-se os grupos de instrumentação e solução auxiliar. Sendo o nível de significância adotado de 5\% $(0,05)$ e a regra de decisão definida a partir de $\mathrm{p}=\mathrm{P}\left(\mathrm{H}>\mathrm{H}_{0}\right)$, probabilidade de que o valor da estatística $H$ seja maior do que seu valor observado $\left(H_{0}\right)$ nos dados da amostra, conforme se segue: se $p$ for menor do que 0,05 , o valor $\mathrm{H}_{0}$ foi significante e a hipótese sob teste rejeitada e, em caso contrário, o valor $\mathrm{H}_{0}$ não significante e a hipótese sob teste não rejeitada.

Se essa hipótese foi rejeitada, para detectar-se onde ocorreu à diferença significante foi aplicado um teste adicional entre as amostras em questão. 
As tabelas contida nos anexos 1, 2 e 3, contém dados individuais do experimento que representam os escores dos 3 (três) examinadores quando a observação das 160 (cento e sessenta) fotomicrografias.

Para melhor interpretação e compreensão os resultados foram divididos em partes.

Tabela 2 - Comparação entre o terço médio e apical, independente, das técnicas ou das soluções quanto a presença de smear layer

(Comparação de dois grupos independentes - Teste não paramétrico de Mann-Whitney)

\begin{tabular}{cccc}
\hline Grupo & Soma de postos & N. de valores & Posto médio \\
\hline Médio & 6183,5 & 80 & 77,2938 \\
Apical & 6696,5 & 80 & 83,7063 \\
\hline
\end{tabular}

Probabilidade $=0.3142$ $\mathrm{P}>0,05$ - Não significante

A análise dos resultados, com os postos médios, da tabela 2 revelam que não há diferença estatística. Sendo que, em valores numéricos o terço médio apresentou o menor resultado. 
Tabela 3 - Comparação global das técnicas de instrumentação com o hipoclorito de sódio $1 \%$ quanto à presença de smear layer no terço médio

(Comparação de 4 grupos independentes -Teste não paramétrico de Kruskal-Wallis) $\mathrm{H}=14.0869 \quad$ Graus de liberdade $=3$

\begin{tabular}{cccc}
\hline Grupo & Soma de postos & Posto médio & Número \\
\hline Manual & 250,0 & 25,00 & 10 \\
$\mathrm{~K}^{3} \circledR$ & 127,0 & 12,70 & 10 \\
ProTaper ${ }^{\circledR}$ & 193,0 & 19,30 & 10 \\
Race ${ }^{\circledR}$ & 250,0 & 25,00 & 10
\end{tabular}

Probabilidade $=0.0028$

$P<0,05$ - Significante

Nas comparações individuais, foram constatadas diferenças significantes quando da comparação entre o sistema $K^{3}{ }^{\circledR}$ com o método manual e com o sistema $\operatorname{RaCe}{ }^{\circledR}$, não havendo diferenças estatísticas entre as demais comparações.

Tabela 4 - Comparação global das técnicas de instrumentação com o hipoclorito de sódio 1\% quanto à presença de smear layer no terço apical

(Comparação de quatro grupos independentes - Teste não paramétrico de Kruskal-Walis)

$\mathrm{H}=5,1250 \quad$ Graus de liberdade $=3$

\begin{tabular}{cccc}
\hline Grupo & Soma de postos & Posto médio & Número \\
\hline Manual & 252,0 & 25,20 & 10 \\
$\mathrm{~K}^{3}{ }^{\circledR}$ & 205,0 & 20,50 & 10 \\
ProTaper ${ }^{\circledR}$ & 208,5 & 20,85 & 10 \\
RaCe ${ }^{\circledR}$ & 154,5 & 15,45 & 10 \\
\hline
\end{tabular}

Probabilidade $=0,1629$ $\mathrm{P}>0,05$ - Não Significante

Nas comparações individuais, não foram verificadas diferenças significantes, no entanto, em valores numéricos o grupo do RaCe ${ }^{\circledR}$ apresentou menor resultado, seguido pelo $\mathrm{K}^{3} \circledast$. 
Tabela 5 - Comparação global das técnicas de instrumentação com 0 hipoclorito de sódio 1\% quanto à presença de smear layer independente do terço

(Comparação de quatro grupos independentes - Teste não paramétrico de Kruscal-Walis) $\mathrm{H}=9,2116 \quad$ Graus de liberdade $=3$

\begin{tabular}{cccc}
\hline Grupo & Soma de postos & Posto médio & Número \\
\hline Manual & 995,0 & 49,75 & 20 \\
$\mathrm{~K}^{3}{ }$ & 647,0 & 32,35 & 20 \\
ProTaper ${ }^{\circledR}$ & 789,5 & 39,48 & 20 \\
RaCe ${ }^{\circledR}$ & 808,5 & 40,43 & 20 \\
\hline
\end{tabular}

Probabilidade $=0,02661$ $\mathrm{P}<0,05$ - Significante

Nas comparações individuais foi constatada diferença significante entre o grupo do sistema $\mathrm{K}^{3} \circledR$ em relação ao método manual, sendo aquele com menor resultado. 
Tabela 6 - Comparação global das técnicas instrumentação com 0 gluconato de clorexidina $0,12 \%$ quanto à presença de smear layer no terço médio

(Comparação de 4 grupos independentes -Teste não paramétrico de Kruskal-Wallis) $\mathrm{H}=6,0335$

Graus de liberdade $=3$

\begin{tabular}{cccc}
\hline Grupo & Soma de postos & Posto médio & Número \\
\hline Manual & 136,5 & 13,65 & 10 \\
$\mathrm{~K}^{3} \circledR$ & 202,5 & 20,25 & 10 \\
ProTaper ${ }^{\circledR}$ & 232,5 & 23,25 & 10 \\
RaCe ${ }^{\circledR}$ & 248,5 & 24,85 & 10 \\
\hline
\end{tabular}

Probabilidade $=0,1100$

$P>0,05$ - Não Significante

Nas comparações individuais observou-se que não houve diferença entre os grupos estudados.

Tabela 7 - Comparação global das técnicas de instrumentação com o gluconato de clorexidina 0,12\% quanto à presença de smear layer no terço apical

(Comparação de 4 grupos independentes -Teste não paramétrico de Kruskal-Wallis) $\mathrm{H}=2,8816 \quad$ Graus de liberdade $=3$

\begin{tabular}{cccc}
\hline Grupo & Soma de postos & Posto médio & Número \\
\hline Manual & 180,0 & 18,00 & 10 \\
$\mathrm{~K}^{3} \circledR$ & 245,0 & 24,50 & 10 \\
ProTaper ${ }^{\circledR}$ & 179,0 & 17,90 & 10 \\
RaCe ${ }^{\circledR}$ & 216,0 & 21,60 & 10 \\
\hline Probabilidade $=0,4102$ & \multicolumn{2}{c}{$\mathrm{P}>0,05$ - Não Significante }
\end{tabular}

Os resultados estatísticos evidenciaram que não houve diferença entre os grupos de instrumentação testados. 
Tabela 8 - Comparação global das técnicas instrumentação com 0 gluconato clorexidina $0,12 \%$ quanto à presença de smear layer independente do terço

(Comparação de 4 grupos independentes -Teste não paramétrico de Kruskal-Wallis)

$\mathrm{H}=5,4417 \quad$ Graus de liberdade $=3$

\begin{tabular}{cccc}
\hline Grupo & Soma de postos & Posto médio & Número \\
\hline Manual & 629,0 & 31,45 & 20 \\
$\mathrm{~K}^{3}{ }$ & 872,5 & 43,63 & 20 \\
ProTaper ${ }^{\circledR}$ & 816,0 & 40,80 & 20 \\
RaCe ${ }^{\circledR}$ & 922,5 & 46,13 & 20 \\
\hline
\end{tabular}

Probabilidade $=0,1422$

$P>0,05$ - Não Significante

Dentro dos valores obtidos no posto médio de cada grupo, ficou evidente que não houve diferença estatística entre os grupos analisados. 
Tabela 9 - Comparação global das técnicas de instrumentação utilizadas, independentes das soluções, na limpeza das paredes dos canais radiculares no terço médio

(Comparação de 4 grupos independentes -Teste não paramétrico de Kruskal-Wallis) $\mathrm{H}=7,1844$ Graus de liberdade $=3$

\begin{tabular}{cccc}
\hline Grupo & Soma de postos & Posto médio & Número \\
\hline Manual & 778,0 & 38,90 & 20 \\
$\mathrm{~K}^{3} \circledR$ & 642,0 & 32,10 & 20 \\
ProTaper $®$ & 836,0 & 41,80 & 20 \\
RaCe $®$ & 984,0 & 49,20 & 20 \\
\hline
\end{tabular}

Probabilidade $=0,6625$ $P>0,05$ - Não Significante

Não houve diferença estatística entre os grupos estudados.

Tabela 10 - Comparação global das técnicas de instrumentação utilizadas, independentes das soluções, quanto a presença de smear layer no terço apical

(Comparação de 4 grupos independentes -Teste não paramétrico de Kruskal-Wallis) $\mathrm{H}=2,1849 \quad$ Graus de liberdade $=3$

\begin{tabular}{cccc}
\hline Grupo & Soma de postos & Posto médio & Número \\
\hline Manual & 860,5 & 43,03 & 20 \\
$\mathrm{~K}^{3} \circledR$ & 887,0 & 44,35 & 20 \\
ProTaper ${ }^{\circledR}$ & 764,5 & 38,23 & 20 \\
RaCe ${ }^{\circledR}$ & 728,0 & 36,40 & 20
\end{tabular}

Probabilidade $=0,5350$ $P>0,05$ - Não Significante

Após observação dos resultados, nota-se que não houve diferença entre os grupos testados. 
Tabela 11 - Comparação global das técnicas de instrumentação utilizadas, independentes das soluções e terço, quanto à presença de smear layer.

(Comparação de 4 grupos independentes -Teste não paramétrico de Kruskal-Wallis) $\mathrm{H}=1,5098 \quad$ Graus de liberdade $=3$

\begin{tabular}{cccc}
\hline Grupo & Soma de postos & Posto médio & Número \\
\hline Manual & 3262,0 & 81,55 & 40 \\
$\mathrm{~K}^{3} \circledR$ & 3005,0 & 75,13 & 40 \\
ProTaper ${ }^{\circledR}$ & 3174,0 & 79,35 & 40 \\
RaCe ${ }^{\circledR}$ & 3439,0 & 85,98 & 40 \\
\hline Probabilidade $=0,6801$ & \multicolumn{2}{r}{ P }
\end{tabular}

Segundo resultados estatísticos não houve diferença entre os grupos analisados. 
Tabela 12 - Comparação da presença de smear layer nas paredes dos canais radiculares das soluções químicas auxiliares empregadas, hipoclorito de sódio 1\% e gluconato de clorexidina 0,12\%, independente da técnica utilizada no terço médio

(Comparação entre dois grupos independentes - Teste não paramétrico de Mann-Whitney)

\begin{tabular}{cccc}
\hline Grupo & Soma de postos & N. de valores & Posto médio \\
\hline Clorexidina 0,12\% & 1353,5 & 40 & 33,8375 \\
Hipoclorito de sódio 1\% & 1886,5 & 40 & 47,1625 \\
\hline Probabilidade $=0,0036$ & & & $\mathrm{P}<0,05$ - Significante
\end{tabular}

As comparações entre as amostras demonstraram que houve diferença estatística, logo ocorreu evidência amostral para se rejeitar a hipótese de igualdade entre as soluções, sendo que a clorexidina apresentou menor resultado.

Tabela 13 - Comparação da presença de smear layer nas paredes dos canais radiculares das soluções químicas auxiliares empregadas, hipoclorito de sódio 1\% e gluconato de clorexidina 0,12\%, independente da técnica utilizada no terço apical

(Comparação entre dois grupos independentes - Teste não paramétrico de Mann-Whitney)

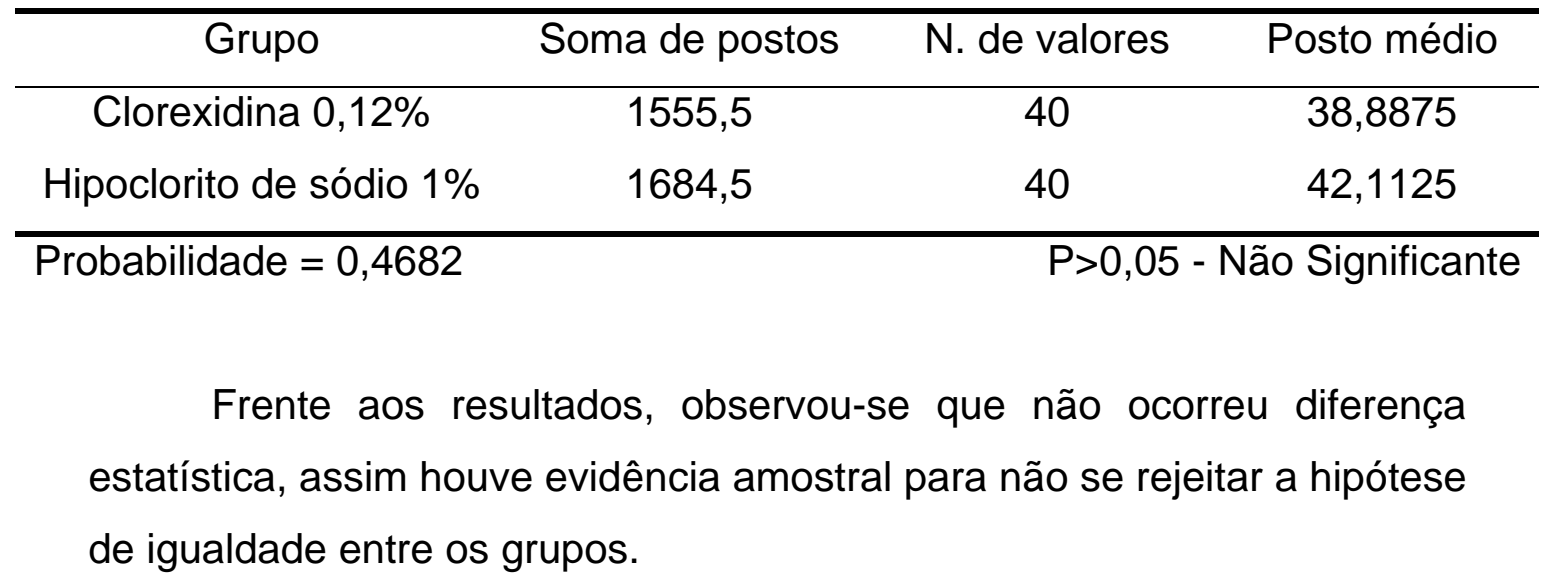


Tabela 14 - Comparação da presença de smear layer nas paredes dos canais radiculares das soluções químicas auxiliares empregadas, hipoclorito de sódio 1\% e gluconato de clorexidina 0,12\%, independente da técnica utilizada, visão global

(Comparação entre dois grupos independentes - Teste não paramétrico de Mann-Whitney)

\begin{tabular}{cccc}
\hline Grupo & Soma de postos & N. de valores & Posto médio \\
\hline Clorexidina 0,12\% & 5754,5 & 80 & 71,9313 \\
Hipoclorito de sódio 1\% & 7125,5 & 80 & 89,0688 \\
\hline Probabilidade $=0,0072$ & & & $\mathrm{P}<0,05$ - Significante
\end{tabular}

As comparações entre as amostras mostraram que ocorreu diferença estatística, logo houve evidência amostral para se rejeitar a hipótese de igualdade quanto à presença de smear layer entre as soluções, sendo que o grupo do glucanato de clorexidina $0,12 \%$ apresentou o menor resultado. 
O preparo biomecânico dos canais radiculares é uma das fases mais importantes da terapêutica endodôntica, buscando a limpeza, sanificação e modelagem dos canais radiculares e de todo sistema endodôntico ${ }^{52,123}$.

O conteúdo presente no canal radicular quer seja polpa viva, quer seja polpa necrótica e seus sub-produtos, deve ser removido com a ação conjunta dos instrumentos endodônticos concomitante com as substâncias químicas auxiliares.

A ação dos instrumentos, manuais ou rotatórios, sobre a dentina faz com que a matriz mineralizada se fragmente, originando debris e subunidades globulares que se espalham sobre as paredes dentinárias, formando uma camada de 1 a $2 \mu \mathrm{m}$ de espessura conhecida como smear layer. Quando se examina a smear layer com auxílio do microscópio eletrônico de varredura, à primeira vista pode-se achar que esta camada é impermeável, no entanto, experimentos realizados in vivo e in vitro mostram que substâncias de vários pesos moleculares são capazes de ultrapassá-la ${ }^{98,99}$.

Cabe ressaltar que a irrigação, acompanhada pela aspiração, é um precioso método auxiliar do preparo do canal radicular. Enquanto o instrumento atua excisionando a dentina e modelando a forma do canal radicular, as soluções irrigantes atuam sobre os debris, smear layer e smear plug. As soluções irrigantes agem também pela ação hidráulica, pois sua simples circulação, irrigação e aspiração eliminam os debris do interior dos canais radiculares ${ }^{38}$.

A Endodontia, no decorrer do seu desenvolvimento técnico e biológico, tem buscado o aperfeiçoamento dos instrumentos endodônticos, das técnicas de preparo dos canais radiculares e de soluções irrigantes que possam realizar suas funções químicas, biológicas e microbiológicas. Estas evoluções visam também à simplificação dos passos operatórios, menor tempo de trabalho e, conseqüentemente, conforto para o profissional e paciente, nem por isso abrindo mão do processo da tríade: modelagem, limpeza e desinfecção. 
As substâncias químicas auxiliares agem em dois momentos durante o preparo biomecânico do canal radicular. Inicialmente, durante a ação dos instrumentos, lubrificando-os, mantendo as partículas orgânicas e inorgânicas em suspensão, diminuindo o atrito e promovendo ação desinfetante do sistema de canais radiculares. Em segundo momento age ao final, de maneira física, do processo de irrigação e aspiração com o fluxo da própria solução no interior do canal radicular.

Conseqüentemente, a troca freqüente e o volume da solução química auxiliar influem na capacidade de remoção da smear layer nos canais radiculares frente à complexidade anatômica desta área ${ }^{13,}$ 59, 116, 124, 152 independente da técnica utilizada. Vários estudos têm mostrado que o volume da solução irrigante influencia e é diretamente proporcional a limpeza do canal radicular, ou seja, quanto maior o volume maior a capacidade de limpeza ${ }^{13,57,152}$.

Neste estudo a irrigação foi contínua e copiosa, dentro normalmente do que se faz em clínica, sem que houvesse variação do volume. Assim padronizamos o volume de $10 \mathrm{~mL}$ de cada solução irrigante por canal radicular, independente da técnica de instrumentação por considerarmos suficiente e pouco além daqueles que outros pesquisadores utilizaram ${ }^{13,57}$.

A profundidade de penetração da agulha de irrigação, também, desempenha papel fundamental na remoção de smear layer do canal radicular $^{124}$. Essa maior profundidade da agulha, com certeza, é alcançada pela técnica que promover maior alargamento dos terços cervical, médio e, por fim, apical.

Assim como o calibre da agulha utilizada para irrigação, também, constitui um detalhe de extrema relevância, visto que, quanto maior o calibre, mais resistência mecânica para atingir o terço apical. Conseqüentemente, quanto maior a sua profundidade de penetração, maior a capacidade para remoção de smear layer ${ }^{36}$. Neste estudo, as agulhas de irrigação e aspiração foram introduzidas em um nível numérico constante com auxílio de cursores endodônticos, para todos os grupos, 
não se variando a seringa de irrigação bem como a bomba de sucção; não tornando-se variáveis por alterações nos resultados da nossa pesquisa.

No que se refere à escolha das soluções irrigantes, buscou-se selecionar as mais utilizadas. O hipoclorito de sódio foi eleito porque apresenta propriedades bem exploradas nas pesquisas endodônticas e a clorexidina porque apresenta somente algumas propriedades avaliadas, deixando ainda lacunas, mas que pode ter potencial para ser empregada na terapêutica endodôntica com maior amplitude e segurança.

Sobre a concentração das soluções foram estabelecidos em níveis baixos, 1\% para solução aquosa de hipoclorito de sódio e 0,12\% para a solução aquosa de gluconato de clorexidina, baseados na ciência de que os efeitos lesivos causados por uma substância química auxiliar desinfetante sobre os tecidos periapicais dependem de sua concentração, toxicidade, tempo de ação e de área de contato com os tecidos. Por outro lado, quando diminuímos a concentração das soluções auxiliares, reduzimos também, a capacidade em dissolver tecidos orgânicos, no entanto, sem alteração considerável de sua ação antimicrobiana ${ }^{69,139}$.

A região apical foi protegida com cera utilidade e selada com cola Araldite ${ }^{\circledR}$, com intuito de evitar o fluxo contínuo da solução para o exterior do canal radicular, como também, as amostras foram acomodadas em base específica para padronizar a instrumentação, eliminando posições privilegiadas entre os grupos ${ }^{10,95,105,153}$.

A escolha sobre os dentes, incisivos centrais e laterais inferiores, baseou-se que na sua maioria apresentam um canal estreito no sentido proximal o que dificulta a ação dos instrumentos endodônticos e penetração da solução irrigante ${ }^{61,84}$.

Este grupo dental permitiu avaliar a presença de smear layer no terço médio e apical sem que o volume do canal, nesta região, fosse amplo com nos dentes anteriores superiores ou curvos como nas raízes vestibulares de molares superiores e mesiais de molares inferiores, o que poderiam interferir, facilitando ou dificultando a ação das soluções 
irrigadoras e/ou das técnicas, quanto a presença ou não de smear layer na região radicular em avaliação. Por outro lado, quando se trabalha com dentes naturais deve-se lembrar da existência de fatores inerentes como a variação da dureza dentinária em função da idade, sexo e tipos dentários $^{72,128,151 .}$

Dentre as técnicas de instrumentação do canal radicular, podemos citar os que têm por alicerce o princípio do preparo escalonado, que se recua progressiva e uniformemente os instrumentos. Por exemplo, a escalonada de $\operatorname{CLEM}^{35}$ a instrumentação incremental de WEINE et al. ${ }^{147}$; o preparo telescópico de MARTIN ${ }^{88}$, a limpeza e modelagem de SCHILDER $^{124}$, a limagem ápice-coroa de WALTON ${ }^{144}$, alargamento ápicecoroa de MULLANEY ${ }^{93}$ e o preparo cônico e escalonado de WEINE ${ }^{146}$. Assim como há as técnicas que têm por base o preparo no sentido coroaápice, por exemplo: a técnica coroa-ápice de GOERIG; MICHELICH; $\mathrm{SCHULT}^{58}$, a técnica coroa-ápice de FAVA ${ }^{47}$; a técnica mista de preparo radicular de HOLLAND et al. ${ }^{73}$, o preparo coroa-ápice sem pressão de MARSHALL; PAPPIN ${ }^{87}$, e a técnica de Oregon modificada de BERBERT et al. ${ }^{22}$.

Todavia o alargamento prévio do terço cervical é de suma importância, pois cria condições propícias a posterior modelagem do terço médio e apical, conseqüentemente, melhorando o desempenho no preparo biomecânico nessa região diminuindo a possibilidade de degraus, perfuração e fratura do instrumento, favorece a manutenção do comprimento de trabalho, colocação de medicação intracanal e do material obturador, menor índice de dor pós-operatória, menor tempo de

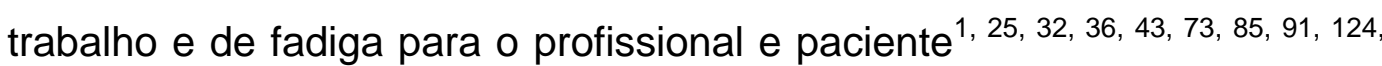
144, 147, 148 facilitando, inclusive, a irrigação e aspiração da solução auxiliar da instrumentação, o que é considerado chave fundamental para o sucesso no desbridamento e da desinfecção ${ }^{55}$. Conseqüentemente, tudo somado resultou na opção pela técnica do tipo coroa - ápice.

Em nosso trabalho foi escolhido aumento de 1.000 vezes (1000x) por se tratar de um valor já consagrado pela literatura científica acorde os 
trabalhos de BOLANOS; JENSEN ${ }^{25}$, 1980; $\quad$ AUN $^{10}, 1985$; PROKOPOWITSCH ${ }^{108}$, 1988; AUN $^{9}, 1990$ e ROTA ${ }^{113}$, 2003 para melhor visualização em microscopia eletrônica de varredura dos canalículos dentinários e avaliação de smear layer.

As fotomicrografias obtidas da microscopia eletrônica de varredura foram tiradas de regiões mais representativas, localizadas nos terços médio e apical.

O método de avaliação, os escores estabelecidos, quanto à presença de smear layer após uso das substâncias auxiliares e instrumentos empregados no preparo biomecânico do canal radicular baseou-se nos trabalhos da literatura 54, 89, 95, 105, 113, 132, 136 com algumas adaptações pertinentes ao caso.

Sendo assim, para que este método de avaliação fosse o mais confiável possível, foi entregue a cada avaliador um gabarito de cinco fotomicrografias (Figura 4) As quais caracterizavam cada condição da parede dentinária. Após o preenchimento de suas respectivas tabelas (anexo 1, 2 e 3) realizou-se a intersecção entre os valores coincidentes (anexo 4), uniformizando as avaliações.

Em nossos resultados quando o teste de Mann Whitney foi aplicado, entre o terço médio e apical, independente das técnicas de instrumentação ou das soluções testadas, observou-se que não houve diferenças estatisticamente significantes ao nível de 5\% entre os grupos estudados (Tabela 2).

Nesse estudo, o preparo cervical foi realizado previamente em todas as técnicas, seja com os instrumentos rotatórios ou com as brocas de Gates Glidden na técnica manual mista invertida; no entanto, não foi verificada as características deste terço cervical, uma vez que as maiores dificuldades de instrumentação e limpeza encontram-se nos terços médio e apical ${ }^{106,143}$.

A busca por melhores condições de preparos, durante a terapia endodôntica, têm trazido alterações quanto às técnicas e aos instrumentos, principalmente com ênfase às técnicas coroa-ápice e, 
concomitantemente a isso, a introdução dos instrumentos rotatórios que surgiram com a promessa de consentir maior ampliação do canal radicular, sem causar deformidades.

Pelas tabelas 12, 13 e 14 pudemos observar que em relação às soluções testadas, independentes da técnica utilizada, a solução de gluconato de clorexidina $0,12 \%$ propiciou uma remoção maior da quantidade de smear layer das paredes dentinárias numa visão global independente do terço envolvido quando comparado ao hipoclorito de sódio 1\%, muito embora esses achados contrariem as observações de CHAVES $^{31}$, MARCHESAN et al. ${ }^{86}$ e ROTA $^{113}$. Isso pode ser perfeitamente esclarecido quando se analisam os fatores que influenciam diretamente o mecanismo de ação do hipoclorito, como o pH, temperatura e concentração. No tocante ao poder solvente das soluções, SIQUEIRA ${ }^{127}$ encontrou resultados idênticos tanto para a Clorexidina a $\%$ como para o hipoclorito de sódio a $5 \%$.

PÉCORA et al ${ }^{102}$ observou que há perda do teor de cloro na solução de hipoclorito dependendo das condições de armazenagem, sendo que a perda do teor é aumentada quando em ambiente com luminosidade e temperatura excessiva, logo, o local ideal de armazenagem seria em vidros de cor âmbar e temperatura de $9^{\circ} \mathrm{C}$. Conseqüentemente, há perda da capacidade de solvência de tecidos quando esses princípios não são seguidos ${ }^{63,67,69}$. Não foi o caso deste trabalho, pois a solução de hipoclorito uma vez aviada foi armazenada dentro das condições ideais necessárias ao produto até o momento de sua utilização.

Por outro lado, o poder de dissolução é diretamente proporcional à concentração da solução de hipoclorito de sódio ${ }^{67,134}$. Uma vez que se optou por uma concentração baixa, no caso em particular 1\%, o poder de dissolução tecidual fica diminuído.

A solução de hipoclorito de sódio é muito utilizada para irrigação dos canais radiculares devido algumas de suas boas propriedades, no 


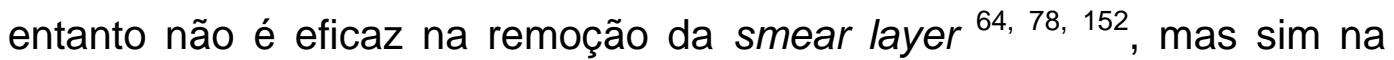
dissolução de componentes orgânicos ${ }^{20,63}$.

A solução de gluconato de clorexidina tem sido estudada em suas mais diferentes propriedades como, por exemplo, atividade antimicrobiana, substantividade, biocompatibilidade e ação sobre os lipopolissacarídeos (LPS) sendo uma alternativa frente ao hipoclorito. Entretanto, a capacidade de remoção de smear layer das paredes dos canais radiculares da clorexidina exige mais estudos, uma vez que a literatura carece dessa informação.

YAMASHITA et al. ${ }^{153}, 2003$ avaliaram in vitro a presença de smear layer nas paredes dos canais radiculares nos terços cervical, médio e apical, por meio da microscopia eletrônica de varredura, após irrigação com clorexidina $2 \%$ e hipoclorito de sódio 2,5\%, concluíram que o grupo do hipoclorito de sódio apresentou resultado semelhante ao da clorexidina no terço cervical. Da mesma forma que CHEUNG; STOCK ${ }^{33}, 1993$ também não encontraram diferenças estatísticas quanto à presença de smear layer entre a solução de hipoclorito de sódio $1 \%$ e a solução de gluconato de clorexidina 0,5\%. Essas observações de alguma forma concordam com nossos achados, muito embora não especifiquem em detalhes os níveis que foram avaliados.

FERRAZ et al. ${ }^{50}, 2001$ da mesma forma, relatam em relação à capacidade de limpeza resultados similares da clorexidina $2 \%$ quando comparado ao hipoclorito de sódio a 5,25\% e resultados melhores para a clorexidina na forma de gel, ainda que se tenha utilizado EDTA previamente a irrigação.

Em nosso estudo, visualizou-se que as fotomicrografias evidenciaram maior número de túbulos dentinários expostos para o grupo do gluconato de clorexidina $0,12 \%$ o que é elucidado pelo fato de que o sal de gluconato de clorexidina é uma substância levemente detergente reduzindo a tensão superficial formando micelas, o que indica que a molécula possui um lado hidrofílico e um lado hidrofóbico 66, 70, 71, 82, conseqüentemente, facilitando sua ação nas paredes dos canais 
radiculares (tabelas 12 e 13). No entanto, a capacidade de remoção de smear layer é inerente aos agentes quelantes ${ }^{116,41}$.

Em relação à eficiência de remoção de dentina quanto aos níveis instrumentados do canal radicular, pudemos observar em todos os grupos que o terço médio sempre apresentava menor smear layer que o apical. WALTERS; BAUMGARTNER; MARSHALL ${ }^{143}$ trabalhando na remoção de debris nos diversos terços radiculares evidenciaram também que de um modo geral o terço apical sempre apresentava uma maior quantidade de debris.

CHAVES $^{31}$ não encontrou diferenças entre o terço cervical e médio na remoção de debris das paredes do canal radicular. De DEUS et al. ${ }^{41}$ afirmou que o terço apical nunca apresentou uma limpeza adequada em relação aos demais. GARCIA FILHO et al. ${ }^{56}$ também relatou que nenhum instrumento foi capaz de limpar completamente o terço apical dos canais e que a qualidade da limpeza está diretamente relacionada à anatomia do canal e não somente ao instrumento utilizado.

A literatura relata a evolução na confecção de novos instrumentos com a finalidade de torná-los mais eficazes e eficientes. Hodiernamente, existem instrumentos mais flexíveis de ligas de níquel-titânio, as quais ganharam cinco vezes mais flexibilidade quando comparadas com as de aço inoxidável ${ }^{81}$.

Congruente a essas mudanças, cada fabricante, na atualidade, desenvolve seu próprio sistema com instrumentos de níquel-titânio, cada qual com diferentes conicidades e formas. Para cada sistema é preconizada uma técnica diferente. A variabilidade, de técnicas e sistemas rotatórios encontrados na atualidade, promove mais confusão que esclarecimentos ${ }^{30}$.

Ao comparamos os grupos de instrumentação manual e rotatórios (ProTaper $\AA, \mathrm{K}^{3} \AA$ e $\mathrm{RaCe} \AA$ ), observamos, segundo nossos resultados, que quando irrigados com o gluconato de clorexidina $0,12 \%$ não há diferenças estatísticas quanto à presença de smear layer nas paredes dentinárias entre os terços observados (Tabelas 6, 7 e 8). 
Independente da solução utilizada, em nossos resultados, o sistema rotatório $\mathrm{K}^{3} \AA$ apresentou os melhores resultados numéricos globais, destacando-se o terço médio (Tabelas 9 e 11), contrariando os achados de GRECCA ${ }^{65}, 2003$ utilizando o $\mathrm{K}^{3} \circledast$ e o ProTaper®.

Analisando os resultados da instrumentação com a solução de hipoclorito de sódio $1 \%$ os resultados mostram-se distintos. O grupo do sistema $\mathrm{K}^{3}{ }^{\circledR}$ apresentou melhor eficácia quanto à exposição dos túbulos dentinários presente no terço médio e na análise global (Tabela 3 e 5), não sendo constante a presença de lascas dentinárias e sim, fragmentos menores dispersos ao longo da parede dentinária (Anexos 17, 18 e 20 fotomicrografia $17.1,18.2$ e 20.2) evidenciando seu ângulo positivo de corte $^{92}$.

Por conseguinte, observando as fotomicrografias 11.1, 12.1, $13.2 \mathrm{e}$ 15.1 (Anexos 11, 12, 13 e 15) se observa lascas, e não fragmentos, dentinários para os grupos do ProTaper ${ }^{\circledR}$ e $\mathrm{RaCe} \AA$, evidenciando supostamente o ângulo de ataque excessivamente positivo contra a

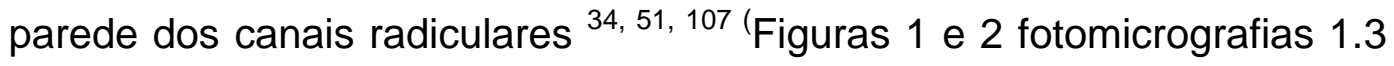
e 2.3).

Segundo o fabricante o $\mathrm{K}^{3} \circledast$ é dotado de alívio da guia radial, uma depressão na superfície posterior, com o intuito de reduzir o atrito com parede do canal, conseqüentemente, facilitando o escoamento em direção coronária da dentina incisada ${ }^{83}$.

O preparo biomecânico do canal radicular visa, principalmente, a modelagem do canal radicular, conseqüentemente eliminando debris e smear layer ${ }^{7,44}$. Logo, a eficácia dos instrumentos, em nosso trabalho, foi avaliada segundo a presença de smear layer no terço médio e apical ${ }^{106}$.

Todas as técnicas, avaliadas nesse estudo, produziram smear layer. Por esta razão, evidenciamos que todos os instrumentos mostraram-se hábeis em atuar cortando as paredes dentinárias, uma vez que a smear layer é criada a partir da ação de corte dos instrumentos contra a estrutura dentinária $68,76,106,107,114,138$. 
Conseguinte, pode-se observar perante os resultados obtidos em nosso trabalho que o sistema $\mathrm{k}^{3}{ }^{\circledR}$ mostrou os melhores valores quanto à exposição da luz dos túbulos dentinários quando irrigado com a solução de hipoclorito de sódio 1\%, no entanto, pela análise das tabelas 3, 4, 5, 6, 7 e 8 pode-se visualizar que todos os sistemas são eficazes na instrumentação dos canais radiculares, dentro dos limites anatômicos pertinentes ao sistema de canais radiculares, sendo que a solução auxiliar é condição essencial fazendo a diferença.

Neste estudo ficou evidente que esses instrumentos endodônticos produziram smear layer que não foi removida pela irrigação e aspiração. Este problema foi observado em todos os grupos em maior ou menor quantidade. Segundo De DEUS et al. ${ }^{41}$ a remoção de debris, provavelmente, está mais relacionada a um fator mecânico, enquanto que a remoção da smear layer está provavelmente mais relacionada a um fator químico.

Conseqüentemente, RUDDLE ${ }^{114}$, 2002; HÜLSMANN et al. ${ }^{74}, 1997$, GAMBARINI $^{54}$, 1999; GRANDINI; BALLERI; FERRARI ${ }^{64}$, 2002, LIM et al. ${ }^{78}, 2003$ recomendam o uso de soluções associadas com agentes quelantes durante o preparo biomecânico do canal radicular com o intuito de remover debris bem como a smear layer.

Dentro de nossos resultados verifica-se que ao confrontarmos os dados da tabela 3 com 9 e 5 com a 11 podemos relatar que o sistema $\mathrm{k}^{3} \circledR$ apresentou resultados constantes, superando os demais grupos quanto a presença de smear layer na presença da solução de hipoclorito de sódio $1 \%$ e independente do líquido irrigante. No entanto, quando na presença da solução de clorexidina $0,12 \%$ os resultados mostraram-se variáveis entre todos os sistemas, inclusive com resultados insatisfatórios em valores numéricos, ainda que sem diferenças estatísticas. (tabelas 6, 7 e 8), no entanto, em valores particulares se observa grandes mudanças quando comparados aos valores da solução de hipoclorito de sódio 1\%, o que nos leva a relatar que todos os sistemas utilizados são aptos para o 
preparo biomecânico do canal radicular, não havendo melhores resultados finais.

Entretanto, áreas não tocadas pelos instrumentos foram observadas, apresentando imagens semelhantes ao do grupo não instrumentado, com a presença de calcosferitas (Anexo 17 e 23 fotomicrografias 17.2 e 23.2). Estas áreas sugerem que os instrumentos ainda são ineficazes, como um todo, para limpeza do sistema de canais radiculares, principalmente frente aos acidentes anatômicos ${ }^{104,}{ }^{106}$, revelando que a anatomia do canal radicular é fator determinante para atuação dos instrumentos endodônticos durante o preparo biomecânico e mesmos os de níquel-titânio mostram-se incapazes de atuar em canais com achatamento. Esses instrumentos freqüentemente produzem um preparo circular, enquanto que as reentrâncias permanecem inalteradas com debris e smear layer ${ }^{111,145}$ o que também foi verificado com a instrumentação manual ratificando outros trabalhos ${ }^{14}$ inclusive quando associado a agentes quelantes ${ }^{132,133}$.

Também é fator digno de nota, que em nosso trabalho houve diferença entre os instrumentos memória nos grupos testados, manual-

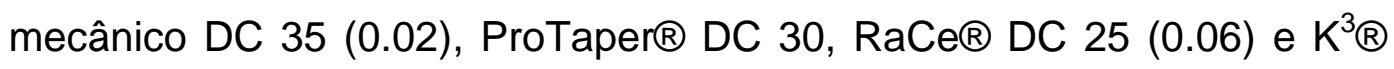
DC 35 (0.06), no entanto, não cremos que isso invalide a fidelidade de nossos resultados, uma vez que a literatura mostra vários estudos com diferenças no instrumento memória, principalmente pela presença de um arsenal muito variado quanto a conicidade, que não influenciaram na leitura dos resultados ${ }^{112,129}$.

SCHÄFER; VLASSIS ${ }^{119,120}$ realizaram um estudo com a finalidade de observar a capacidade do preparo com o sistema ProTaper $\circledast$ e $\mathrm{RaCe} \circledast$ até o diâmetro cirúrgico foi 30 e 35, respectivamente. Os autores argumentam que quando se propõe a comparar a instrumentação com diferentes técnicas ou com diferentes instrumentos faz-se imperativo a semelhança do diâmetro cirúrgico, entretanto, a disponibilidade dos sistemas no mercado não permite tal padronização. 
Como considerações finais e adicionais frente ao número de utilização das limas, não registramos nenhum caso de fratura de instrumentos, tanto à base de níquel-titânio, quanto à base de aço inoxidável.

Segundo ZELADA et al ${ }^{155}$ e YARED et al. ${ }^{154}$ as incidências de fraturas foram verificadas em canais com curvaturas acima de 30 graus, alta velocidade de rotação e inexperiência do operador, porém o torque elevado, acima de $10 \mathrm{~N} / \mathrm{cm}$, não apresentou deformação ou fratura no instrumento de níquel-titânio. Levando em consideração que a instrumentação foi realizada em canais de trajetória retilínea, operador com prévia experiência em sistemas rotatórios, torque baixo e constante nossos estudos estão de acordo com a literatura.

Dentro da literatura avaliada e resultados obtidos é coerente relatar que a ciência ainda carece de informações sobre o assunto, de tal forma que se faz oportuno mais pesquisas in vitro e, se possível, in vivo envolvendo o tema. 
7 Conclusões 
Com base nos resultados, dentro do proposto e das limitações das condições experimentais em que a pesquisa foi conduzida é licito concluir que:

1. A análise dos resultados mostrou que não houve diferença entre os terços analisados, médio e apical, independente das técnicas ou das soluções, muito embora o terço médio tenha apresentado melhores resultados em valores absolutos,

2. Quando irrigados com a solução de hipoclorito de sódio 1\% 0 $\mathrm{K}^{3} \circledast$ apresentou os melhores resultados seguido pelo ProTaper ${ }^{\circledR}, \mathrm{RaCe}^{\circledR}$ e Manual. Existiu diferença estatística apenas do $\mathrm{K}^{3} \circledast$ em relação ao $\mathrm{RaCe} \circledast$ e a técnica Manual,

3. Quando irrigados com a solução de gluconato de clorexidina 0,12\% observamos que não houve diferença entre os métodos de instrumentação,

4. Em relação às soluções irrigadoras a clorexidina se mostrou superior ao hipoclorito no terço médio, independente da técnica de instrumentação utilizada, sendo que no terço apical não houve diferenças entre elas,

5. Os sistemas de instrumentação $\mathrm{K}^{3} \AA$, ProTaper ${ }^{\circledR}$ e $\operatorname{RaCe}{ }^{\circledR}$ deixaram áreas não atuadas, a exemplo da instrumentação Manual. 
Anexos 
Anexo 1 - Valores numéricos atribuído pelo examinador $\mathrm{A}$ o número à esquerda representa o número da fotomicrografia e o valor à direita representa o valor do escore (0 a 4)

\begin{tabular}{|l|l|}
\hline 1. & 4 \\
\hline 2. & 3 \\
\hline 3. & 4 \\
\hline 4. & 4 \\
\hline 5. & 4 \\
\hline 6. & 4 \\
\hline 7. & 4 \\
\hline 8. & 4 \\
\hline 9. & 3 \\
\hline 10. & 1 \\
\hline 11. & 4 \\
\hline 12. & 4 \\
\hline 13. & 2 \\
\hline 14. & 0 \\
\hline 15. & 2 \\
\hline 16. & 0 \\
\hline 17. & 3 \\
\hline 18. & 4 \\
\hline 19. & 4 \\
\hline 20. & 0 \\
\hline 21. & 4 \\
\hline 22. & 2 \\
\hline 23. & 2 \\
\hline 24. & 0 \\
\hline 25. & 3 \\
\hline 26. & 1 \\
\hline 27. & 3 \\
\hline 28. & 3 \\
\hline 29. & 4 \\
\hline 30. & 4 \\
\hline 31. & 3 \\
\hline 32. & 3 \\
\hline 33. & 4 \\
\hline 34. & 0 \\
\hline 35. & 4 \\
\hline 36. & 0 \\
\hline 37. & 2 \\
\hline 38. & 0 \\
\hline 39. & 4 \\
\hline 40. & 3 \\
\hline
\end{tabular}

\begin{tabular}{|l|l|}
\hline 41. & 4 \\
\hline 42. & 4 \\
\hline 43. & 4 \\
\hline 44. & 4 \\
\hline 45. & 4 \\
\hline 46. & 4 \\
\hline 47. & 3 \\
\hline 48. & 4 \\
\hline 49. & 4 \\
\hline 50. & 4 \\
\hline 51. & 1 \\
\hline 52. & 4 \\
\hline 53. & 4 \\
\hline 54. & 4 \\
\hline 55. & 3 \\
\hline 56. & 4 \\
\hline 57. & 4 \\
\hline 58. & 2 \\
\hline 59. & 4 \\
\hline 60. & 4 \\
\hline 61. & 3 \\
\hline 62. & 4 \\
\hline 63. & 3 \\
\hline 64. & 4 \\
\hline 65. & 3 \\
\hline 66. & 0 \\
\hline 67. & 4 \\
\hline 68. & 3 \\
\hline 69. & 3 \\
\hline 70. & 3 \\
\hline 71. & 3 \\
\hline 72. & 4 \\
\hline 73. & 4 \\
\hline 74. & 0 \\
\hline 75. & 4 \\
\hline 76. & 0 \\
\hline 77. & 1 \\
\hline 78. & 0 \\
\hline 79. & 3 \\
\hline 80. & 4 \\
\hline & \\
\hline
\end{tabular}

\begin{tabular}{|c|c|}
\hline 81. & 4 \\
\hline 82. & 4 \\
\hline 83. & 3 \\
\hline 84. & 4 \\
\hline 85. & 4 \\
\hline 86. & 4 \\
\hline 87. & 4 \\
\hline 88. & 4 \\
\hline 89. & 3 \\
\hline 90. & 3 \\
\hline 91. & 4 \\
\hline 92. & 3 \\
\hline 93. & 4 \\
\hline 94. & 4 \\
\hline 95. & 3 \\
\hline 96. & 4 \\
\hline 97. & 4 \\
\hline 98. & 4 \\
\hline 99. & 1 \\
\hline 100. & 4 \\
\hline 101. & 3 \\
\hline 102. & 0 \\
\hline 103. & 3 \\
\hline 104. & 4 \\
\hline 105. & 4 \\
\hline 106. & 4 \\
\hline 107. & 4 \\
\hline 108. & 4 \\
\hline 109. & 3 \\
\hline 110. & 3 \\
\hline 111. & 4 \\
\hline 112. & 4 \\
\hline 113. & 3 \\
\hline 114. & 4 \\
\hline 115. & 4 \\
\hline 116. & 3 \\
\hline 117. & 3 \\
\hline 118. & 3 \\
\hline 119. & 3 \\
\hline 120. & 4 \\
\hline & \\
\hline
\end{tabular}

\begin{tabular}{|c|c|}
\hline 121. & 3 \\
\hline 122. & 4 \\
\hline 123. & 4 \\
\hline 124. & 4 \\
\hline 125. & 4 \\
\hline 126. & 4 \\
\hline 127. & 4 \\
\hline 128. & 4 \\
\hline 129. & 4 \\
\hline 130. & 1 \\
\hline 131. & 1 \\
\hline 132. & 4 \\
\hline 133. & 4 \\
\hline 134. & 0 \\
\hline 135. & 3 \\
\hline 136. & 0 \\
\hline 137. & 4 \\
\hline 138. & 2 \\
\hline 139. & 4 \\
\hline 140. & 4 \\
\hline 141. & 3 \\
\hline 142. & 3 \\
\hline 143. & 3 \\
\hline 144. & 4 \\
\hline 145. & 3 \\
\hline 146. & 2 \\
\hline 147. & 4 \\
\hline 148. & 3 \\
\hline 149. & 3 \\
\hline 150. & 3 \\
\hline 151. & 3 \\
\hline 152. & 4 \\
\hline 153. & 4 \\
\hline 154. & 0 \\
\hline 155. & 3 \\
\hline 156. & 3 \\
\hline 157. & 3 \\
\hline 158. & 2 \\
\hline 159. & 3 \\
\hline 160. & 3 \\
\hline
\end{tabular}


Anexo 2 - Valores numéricos atribuído pelo examinador $\mathrm{B}$ o número à esquerda representa o número da fotomicrografia e o valor à direita representa o valor do escore (0 a 4)

\begin{tabular}{|l|l|}
\hline 1. & 4 \\
\hline 2. & 4 \\
\hline 3. & 3 \\
\hline 4. & 4 \\
\hline 5. & 4 \\
\hline 6. & 4 \\
\hline 7. & 4 \\
\hline 8. & 4 \\
\hline 9. & 4 \\
\hline 10. & 4 \\
\hline 11. & 4 \\
\hline 12. & 4 \\
\hline 13. & 4 \\
\hline 14. & 4 \\
\hline 15. & 3 \\
\hline 16. & 3 \\
\hline 17. & 4 \\
\hline 18. & 4 \\
\hline 19. & 4 \\
\hline 20. & 4 \\
\hline 21. & 3 \\
\hline 22. & 3 \\
\hline 23. & 1 \\
\hline 24. & 0 \\
\hline 25. & 3 \\
\hline 26. & 0 \\
\hline 27. & 4 \\
\hline 28. & 3 \\
\hline 29. & 3 \\
\hline 30. & 4 \\
\hline 31. & 4 \\
\hline 32. & 4 \\
\hline 33. & 4 \\
\hline 34. & 0 \\
\hline 35. & 4 \\
\hline 36. & 0 \\
\hline 37. & 1 \\
\hline 38. & 0 \\
\hline 39. & 4 \\
\hline 40. & 4 \\
\hline & \\
\hline
\end{tabular}

\begin{tabular}{|l|l|}
\hline 41. & 3 \\
\hline 42. & 4 \\
\hline 43. & 4 \\
\hline 44. & 4 \\
\hline 45. & 4 \\
\hline 46. & 4 \\
\hline 47. & 4 \\
\hline 48. & 4 \\
\hline 49. & 4 \\
\hline 50. & 3 \\
\hline 51. & 1 \\
\hline 52. & 4 \\
\hline 53. & 3 \\
\hline 54. & 4 \\
\hline 55. & 4 \\
\hline 56. & 1 \\
\hline 57. & 3 \\
\hline 58. & 1 \\
\hline 59. & 3 \\
\hline 60. & 4 \\
\hline 61. & 3 \\
\hline 62. & 3 \\
\hline 63. & 3 \\
\hline 64. & 3 \\
\hline 65. & 3 \\
\hline 66. & 2 \\
\hline 67. & 4 \\
\hline 68. & 3 \\
\hline 69. & 4 \\
\hline 70. & 3 \\
\hline 71. & 3 \\
\hline 72. & 3 \\
\hline 73. & 4 \\
\hline 74. & 2 \\
\hline 75. & 4 \\
\hline 76. & 4 \\
\hline 77. & 3 \\
\hline 78. & 4 \\
\hline 79. & 3 \\
\hline 80. & 4 \\
\hline & \\
\hline
\end{tabular}

\begin{tabular}{|l|l|}
\hline 81. & 3 \\
\hline 82. & 4 \\
\hline 83. & 3 \\
\hline 84. & 4 \\
\hline 85. & 3 \\
\hline 86. & 4 \\
\hline 87. & 4 \\
\hline 88. & 3 \\
\hline 89. & 3 \\
\hline 90. & 4 \\
\hline 91. & 3 \\
\hline 92. & 4 \\
\hline 93. & 4 \\
\hline 94. & 4 \\
\hline 95. & 3 \\
\hline 96. & 4 \\
\hline 97. & 3 \\
\hline 98. & 4 \\
\hline 99. & 1 \\
\hline 100. & 4 \\
\hline 101. & 3 \\
\hline 102. & 0 \\
\hline 103. & 3 \\
\hline 104. & 3 \\
\hline 105. & 4 \\
\hline 106. & 3 \\
\hline 107. & 3 \\
\hline 108. & 3 \\
\hline 109. & 3 \\
\hline 110. & 4 \\
\hline 111. & 3 \\
\hline 112. & 3 \\
\hline 113. & 4 \\
\hline 114. & 3 \\
\hline 115. & 4 \\
\hline 116. & 4 \\
\hline 117. & 3 \\
\hline 118. & 3 \\
\hline 119. & 4 \\
\hline 120. & 4 \\
\hline & \\
\hline 10.
\end{tabular}

\begin{tabular}{|l|l|}
\hline 121. & 4 \\
\hline 122. & 3 \\
\hline 123. & 4 \\
\hline 124. & 4 \\
\hline 125. & 4 \\
\hline 126. & 4 \\
\hline 127. & 4 \\
\hline 128. & 3 \\
\hline 129. & 3 \\
\hline 130. & 1 \\
\hline 131. & 4 \\
\hline 132. & 4 \\
\hline 133. & 2 \\
\hline 134. & 0 \\
\hline 135. & 3 \\
\hline 136. & 0 \\
\hline 137. & 4 \\
\hline 138. & 4 \\
\hline 139. & 4 \\
\hline 140. & 1 \\
\hline 141. & 4 \\
\hline 142. & 2 \\
\hline 143. & 4 \\
\hline 144. & 4 \\
\hline 145. & 4 \\
\hline 146. & 1 \\
\hline 147. & 3 \\
\hline 148. & 3 \\
\hline 149. & 4 \\
\hline 150. & 4 \\
\hline 151. & 4 \\
\hline 152. & 3 \\
\hline 153. & 4 \\
\hline 154. & 0 \\
\hline 155. & 4 \\
\hline 156. & 4 \\
\hline 157. & 2 \\
\hline 158. & 4 \\
\hline 159. & 4 \\
\hline 160. & 3 \\
\hline
\end{tabular}


Anexo 3 - Valores numéricos atribuídos pelo examinador $\mathrm{C}$ o número à esquerda representa o número da fotomicrografia e o valor à direita representa o valor do escore (0 a 4)

\begin{tabular}{|l|l|}
\hline 1. & 4 \\
\hline 2. & 4 \\
\hline 3. & 4 \\
\hline 4. & 4 \\
\hline 5. & 4 \\
\hline 6. & 4 \\
\hline 7. & 4 \\
\hline 8. & 4 \\
\hline 9. & 3 \\
\hline 10. & 4 \\
\hline 11. & 4 \\
\hline 12. & 4 \\
\hline 13. & 4 \\
\hline 14. & 4 \\
\hline 15. & 3 \\
\hline 16. & 4 \\
\hline 17. & 4 \\
\hline 18. & 4 \\
\hline 19. & 4 \\
\hline 20. & 4 \\
\hline 21. & 3 \\
\hline 22. & 3 \\
\hline 23. & 2 \\
\hline 24. & 1 \\
\hline 25. & 2 \\
\hline 26. & 1 \\
\hline 27. & 4 \\
\hline 28. & 4 \\
\hline 29. & 4 \\
\hline 30. & 4 \\
\hline 31. & 4 \\
\hline 32. & 4 \\
\hline 33. & 4 \\
\hline 34. & 1 \\
\hline 35. & 4 \\
\hline 36. & 1 \\
\hline 37. & 2 \\
\hline 38. & 1 \\
\hline 39. & 4 \\
\hline 40. & 4 \\
\hline & \\
\hline
\end{tabular}

\begin{tabular}{|l|l|}
\hline 41. & 3 \\
\hline 42. & 4 \\
\hline 43. & 3 \\
\hline 44. & 4 \\
\hline 45. & 4 \\
\hline 46. & 4 \\
\hline 47. & 4 \\
\hline 48. & 4 \\
\hline 49. & 2 \\
\hline 50. & 4 \\
\hline 51. & 4 \\
\hline 52. & 4 \\
\hline 53. & 4 \\
\hline 54. & 4 \\
\hline 55. & 4 \\
\hline 56. & 4 \\
\hline 57. & 3 \\
\hline 58. & 4 \\
\hline 59. & 3 \\
\hline 60. & 4 \\
\hline 61. & 3 \\
\hline 62. & 2 \\
\hline 63. & 3 \\
\hline 64. & 4 \\
\hline 65. & 4 \\
\hline 66. & 3 \\
\hline 67. & 4 \\
\hline 68. & 4 \\
\hline 69. & 3 \\
\hline 70. & 4 \\
\hline 71. & 4 \\
\hline 72. & 4 \\
\hline 73. & 4 \\
\hline 74. & 4 \\
\hline 75. & 4 \\
\hline 76. & 3 \\
\hline 77. & 3 \\
\hline 78. & 4 \\
\hline 79. & 4 \\
\hline 80. & 4 \\
\hline & \\
\hline 5
\end{tabular}

\begin{tabular}{|c|c|}
\hline 81. & 3 \\
\hline 82. & 4 \\
\hline 83. & 4 \\
\hline 84. & 4 \\
\hline 85. & 4 \\
\hline 86. & 4 \\
\hline 87. & 4 \\
\hline 88. & 4 \\
\hline 89. & 4 \\
\hline 90. & 3 \\
\hline 91. & 2 \\
\hline 92. & 4 \\
\hline 93. & 4 \\
\hline 94. & 4 \\
\hline 95. & 4 \\
\hline 96. & 1 \\
\hline 97. & 3 \\
\hline 98. & 2 \\
\hline 99. & 4 \\
\hline 100. & 4 \\
\hline 101. & 4 \\
\hline 102. & 4 \\
\hline 103. & 4 \\
\hline 104. & 4 \\
\hline 105. & 4 \\
\hline 106. & 2 \\
\hline 107. & 4 \\
\hline 108. & 4 \\
\hline 109. & 4 \\
\hline 110. & 3 \\
\hline 111. & 3 \\
\hline 112. & 4 \\
\hline 113. & 4 \\
\hline 114. & 2 \\
\hline 115. & 4 \\
\hline 116. & 4 \\
\hline 117. & 4 \\
\hline 118. & 4 \\
\hline 119. & 2 \\
\hline 120. & 4 \\
\hline & \\
\hline 10
\end{tabular}

\begin{tabular}{|c|c|}
\hline 121. & 4 \\
\hline 122. & 3 \\
\hline 123. & 4 \\
\hline 124. & 4 \\
\hline 125. & 3 \\
\hline 126. & 4 \\
\hline 127. & 4 \\
\hline 128. & 3 \\
\hline 129. & 4 \\
\hline 130. & 2 \\
\hline 131. & 4 \\
\hline 132. & 4 \\
\hline 133. & 2 \\
\hline 134. & 1 \\
\hline 135. & 2 \\
\hline 136. & 1 \\
\hline 137. & 4 \\
\hline 138. & 4 \\
\hline 139. & 4 \\
\hline 140. & 1 \\
\hline 141. & 4 \\
\hline 142. & 3 \\
\hline 143. & 4 \\
\hline 144. & 4 \\
\hline 145. & 4 \\
\hline 146. & 1 \\
\hline 147. & 3 \\
\hline 148. & 4 \\
\hline 149. & 4 \\
\hline 150. & 4 \\
\hline 151. & 4 \\
\hline 152. & 4 \\
\hline 153. & 4 \\
\hline 154. & 1 \\
\hline 155. & 3 \\
\hline 156. & 4 \\
\hline 157. & 2 \\
\hline 158. & 2 \\
\hline 159. & 3 \\
\hline 160. & 4 \\
\hline
\end{tabular}


Anexo 4 - Média final (intersecção) entre os escores dos três examinadores. Valor que foi submetido aos cálculos estatísticos.

\begin{tabular}{|c|c|}
\hline 1. & 4 \\
\hline 2. & 4 \\
\hline 3. & 4 \\
\hline 4. & 4 \\
\hline 5. & 4 \\
\hline 6. & 4 \\
\hline 7. & 4 \\
\hline 8. & 4 \\
\hline 9. & 4 \\
\hline 10. & 4 \\
\hline 11. & 4 \\
\hline 12. & 4 \\
\hline 13. & 4 \\
\hline 14. & 4 \\
\hline 15. & 3 \\
\hline 16. & 4 \\
\hline 17. & 4 \\
\hline 18. & 4 \\
\hline 19. & 4 \\
\hline 20. & 4 \\
\hline 21. & 3 \\
\hline 22. & 3 \\
\hline 23. & 2 \\
\hline 24. & 0 \\
\hline 25. & 3 \\
\hline 26. & 0 \\
\hline 27. & 4 \\
\hline 28. & 3 \\
\hline 29. & 3 \\
\hline 30. & 3 \\
\hline 31. & 4 \\
\hline 32. & 4 \\
\hline 33. & 4 \\
\hline 34. & 0 \\
\hline 35. & 4 \\
\hline 36. & 0 \\
\hline 37. & 1 \\
\hline 38. & 0 \\
\hline 39. & 4 \\
\hline 40. & 4 \\
\hline
\end{tabular}

\begin{tabular}{|l|l|}
\hline 41. & 3 \\
\hline 42. & 4 \\
\hline 43. & 4 \\
\hline 44. & 4 \\
\hline 45. & 4 \\
\hline 46. & 4 \\
\hline 47. & 4 \\
\hline 48. & 4 \\
\hline 49. & 4 \\
\hline 50. & 3 \\
\hline 51. & 1 \\
\hline 52. & 4 \\
\hline 53. & 4 \\
\hline 54. & 4 \\
\hline 55. & 4 \\
\hline 56. & 1 \\
\hline 57. & 3 \\
\hline 58. & 2 \\
\hline 59. & 4 \\
\hline 60. & 4 \\
\hline 61. & 3 \\
\hline 62. & 3 \\
\hline 63. & 3 \\
\hline 64. & 4 \\
\hline 65. & 3 \\
\hline 66. & 2 \\
\hline 67. & 4 \\
\hline 68. & 3 \\
\hline 69. & 4 \\
\hline 70. & 3 \\
\hline 71. & 3 \\
\hline 72. & 4 \\
\hline 73. & 4 \\
\hline 74. & 2 \\
\hline 75. & 4 \\
\hline 76. & 4 \\
\hline 77. & 3 \\
\hline 78. & 4 \\
\hline 79. & 3 \\
\hline 80. & 4 \\
\hline & \\
\hline
\end{tabular}

\begin{tabular}{|c|c|}
\hline 81. & 3 \\
\hline 82. & 4 \\
\hline 83. & 3 \\
\hline 84. & 4 \\
\hline 85. & 4 \\
\hline 86. & 4 \\
\hline 87. & 4 \\
\hline 88. & 4 \\
\hline 89. & 3 \\
\hline 90. & 4 \\
\hline 91. & 4 \\
\hline 92. & 4 \\
\hline 93. & 4 \\
\hline 94. & 4 \\
\hline 95. & 3 \\
\hline 96. & 4 \\
\hline 97. & 3 \\
\hline 98. & 4 \\
\hline 99. & 1 \\
\hline 100. & 4 \\
\hline 101. & 3 \\
\hline 102. & 0 \\
\hline 103. & 3 \\
\hline 104. & 4 \\
\hline 105. & 4 \\
\hline 106. & 3 \\
\hline 107. & 4 \\
\hline 108. & 4 \\
\hline 109. & 3 \\
\hline 110. & 4 \\
\hline 111. & 4 \\
\hline 112. & 4 \\
\hline 113. & 4 \\
\hline 114. & 4 \\
\hline 115. & 4 \\
\hline 116. & 3 \\
\hline 117. & 3 \\
\hline 118. & 3 \\
\hline 119. & 4 \\
\hline 120. & 4 \\
\hline & \\
\hline 9
\end{tabular}

\begin{tabular}{|c|c|}
\hline 121. & 4 \\
\hline 122. & 3 \\
\hline 123. & 4 \\
\hline 124. & 4 \\
\hline 125. & 4 \\
\hline 126. & 4 \\
\hline 127. & 4 \\
\hline 128. & 3 \\
\hline 129. & 3 \\
\hline 130. & 1 \\
\hline 131. & 4 \\
\hline 132. & 4 \\
\hline 133. & 2 \\
\hline 134. & 0 \\
\hline 135. & 2 \\
\hline 136. & 0 \\
\hline 137. & 4 \\
\hline 138. & 4 \\
\hline 139. & 4 \\
\hline 140. & 1 \\
\hline 141. & 4 \\
\hline 142. & 2 \\
\hline 143. & 4 \\
\hline 144. & 4 \\
\hline 145. & 4 \\
\hline 146. & 1 \\
\hline 147. & 3 \\
\hline 148. & 3 \\
\hline 149. & 4 \\
\hline 150. & 4 \\
\hline 151. & 4 \\
\hline 152. & 3 \\
\hline 153. & 4 \\
\hline 154. & 0 \\
\hline 155. & 4 \\
\hline 156. & 4 \\
\hline 157. & 2 \\
\hline 158. & 4 \\
\hline 159. & 4 \\
\hline 160. & 3 \\
\hline
\end{tabular}


Anexo 5 - Fotomicrografias do grupo instrumentação manual-mecânico clorexidina 0,12\%. Terço médio.
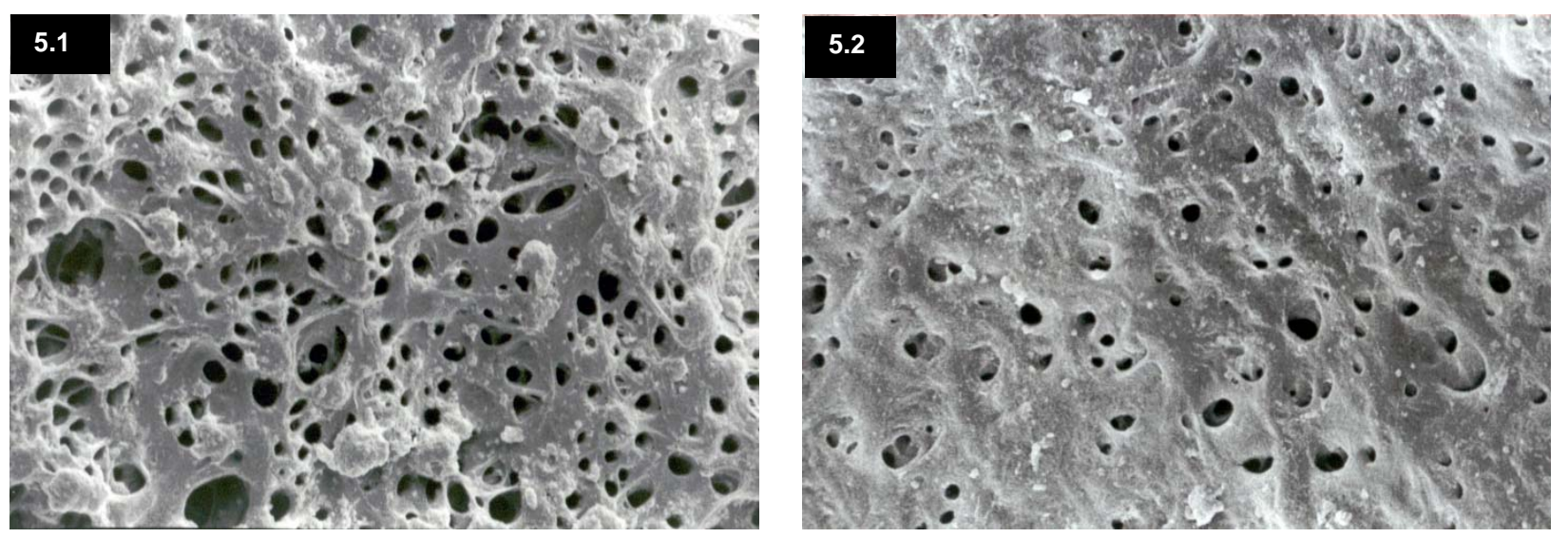

\footnotetext{
Anexo 6 - Fotomicrografias do grupo instrumentação manual-mecânico clorexidina 0,12\%. Terço apical.
}
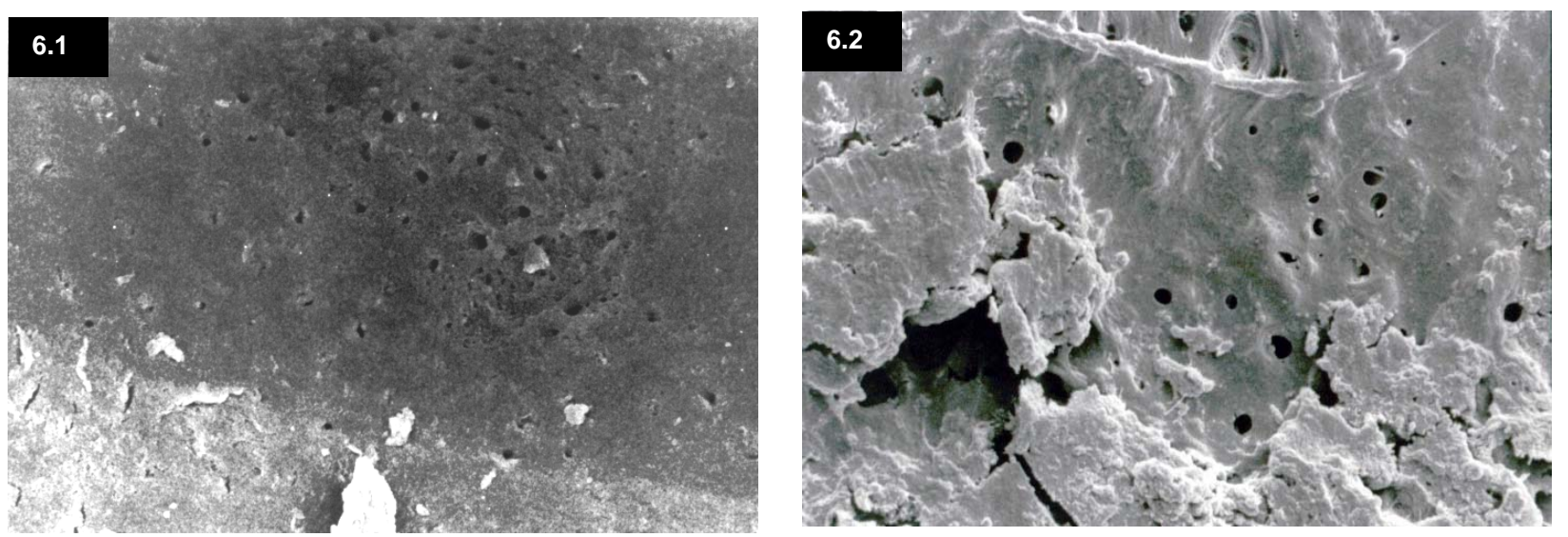
Anexo 7 - Fotomicrografias do grupo instrumentação manual-mecânico hipoclorito de sódio 1\%. Terço médio.
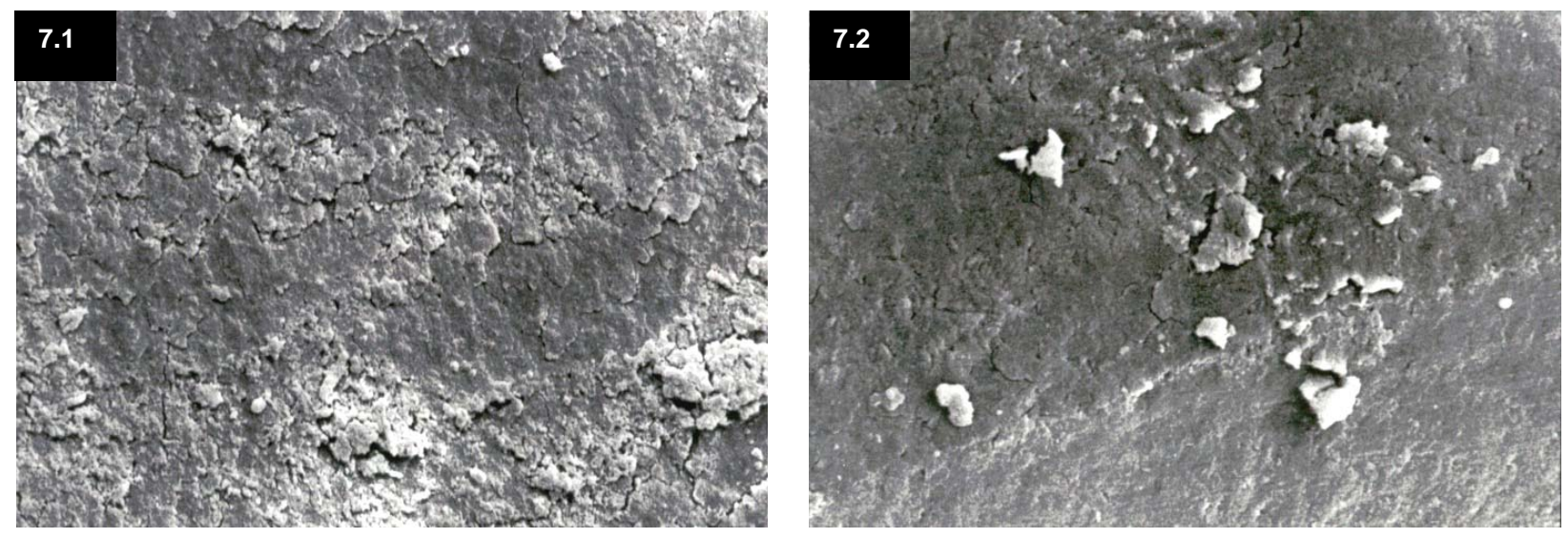

Anexo 8 - Fotomicrografias do grupo instrumentação manual-mecânico hipoclorito de sódio 1\%. Terço apical.
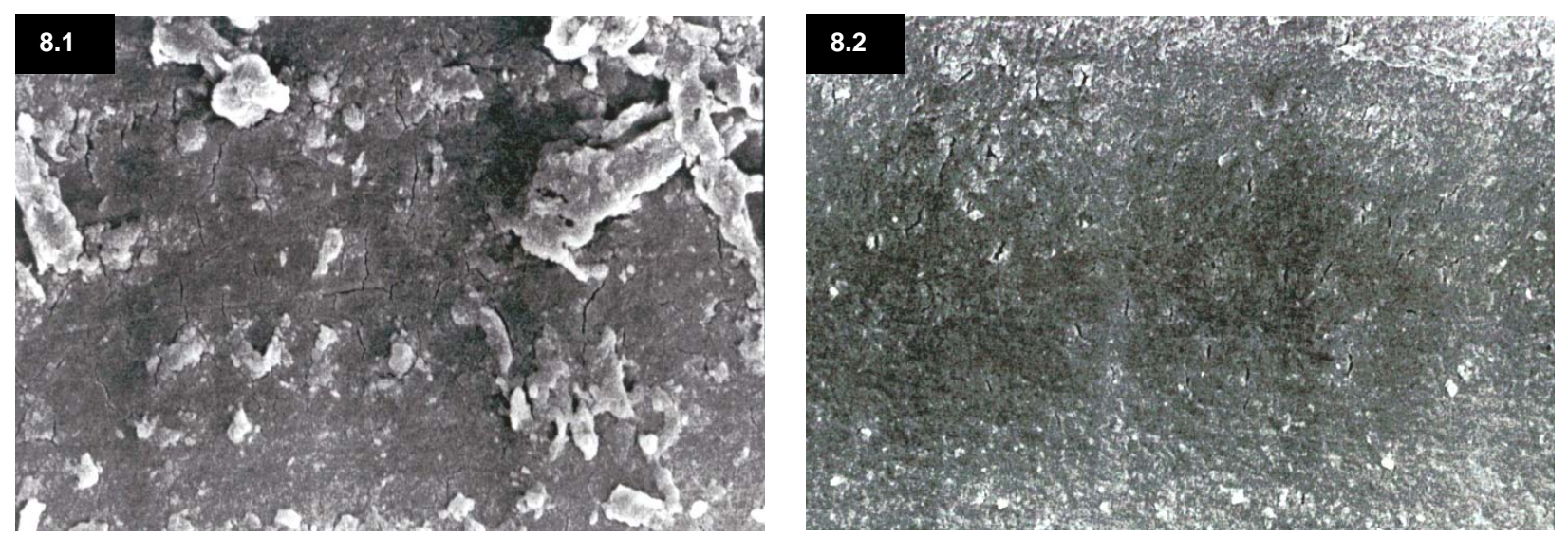
Anexo 9 - Fotomicrografias do grupo instrumentação rotatória grupo ProTaper® - clorexidina 0,12\%. Terço médio.
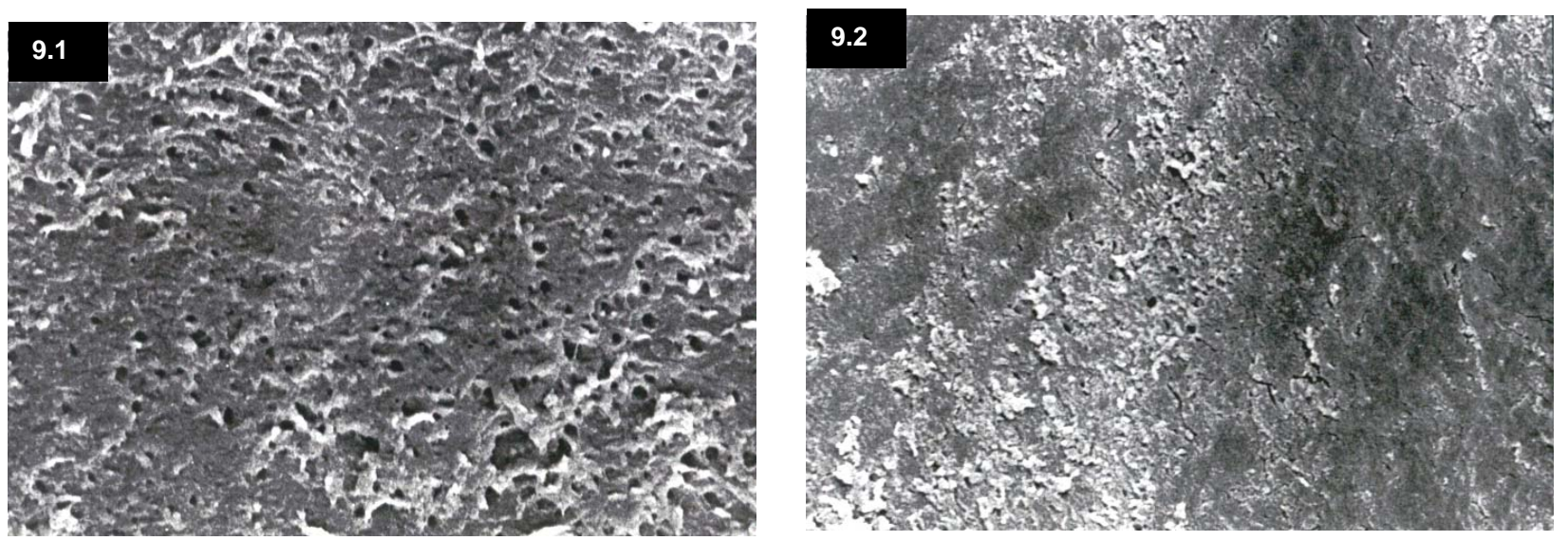

Anexo 10 - Fotomicrografias do grupo instrumentação rotatória grupo ProTaper® - clorexidina 0,12\%. Terço apical.
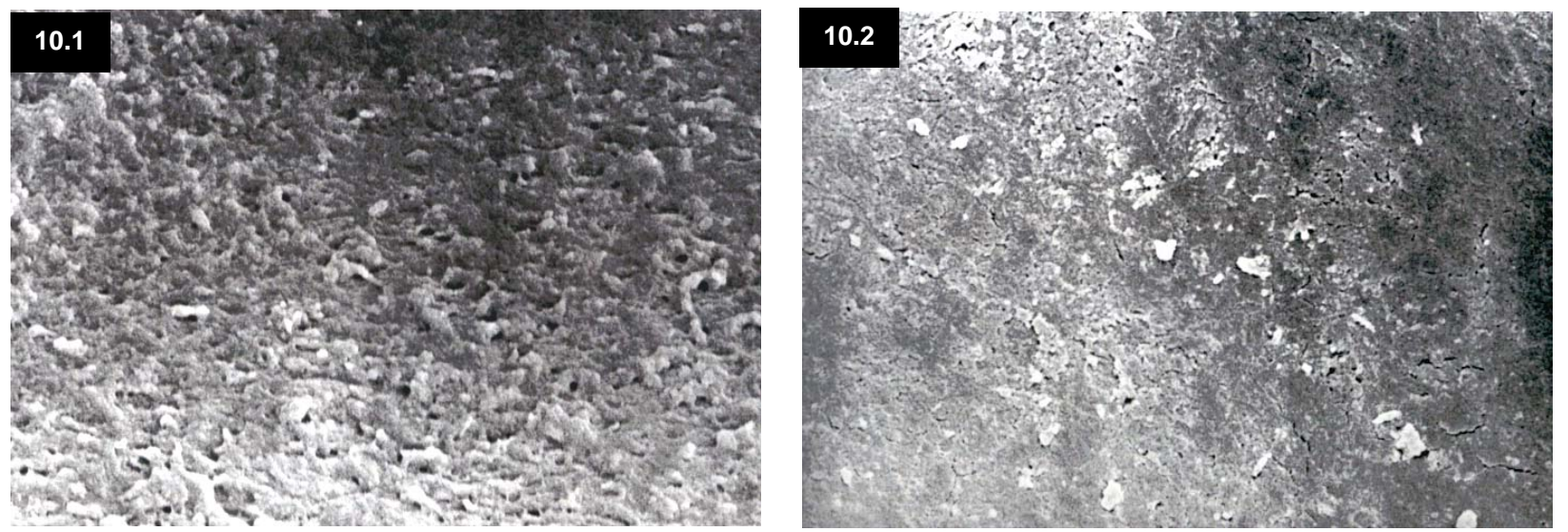
Anexo 11 - Fotomicrografias do grupo instrumentação rotatória grupo ProTaper® - hipoclorito de sódio 1\%. Terço médio.
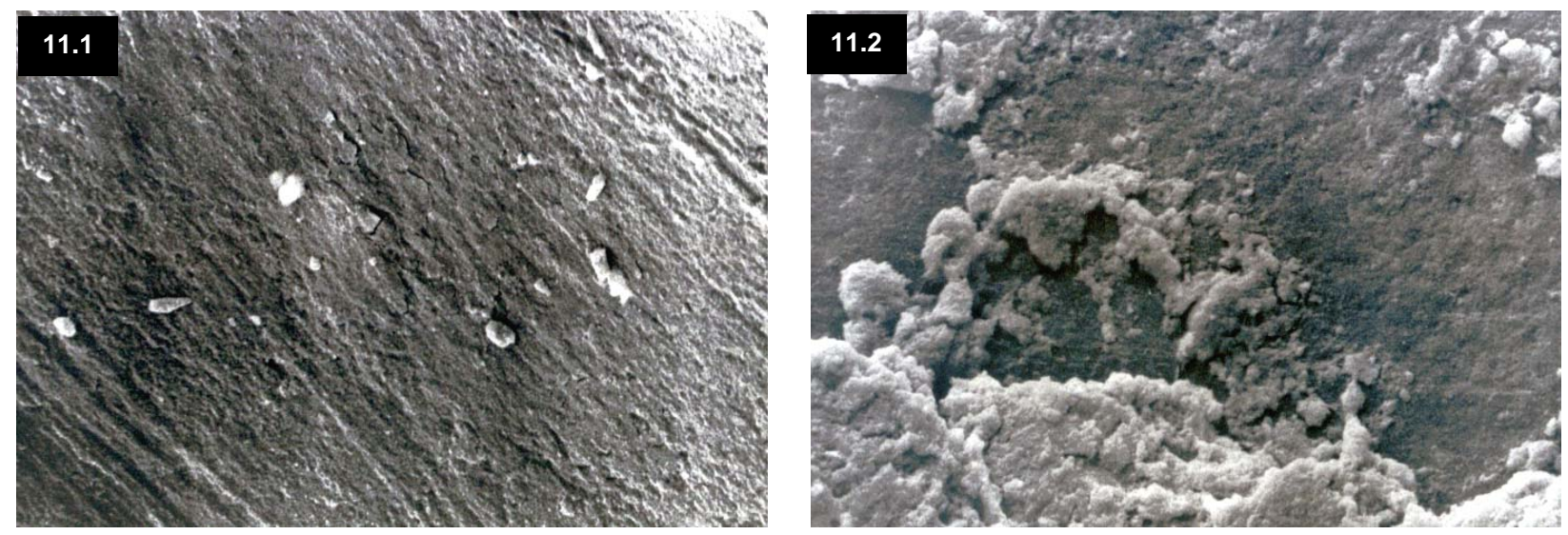

Anexo 12 - Fotomicrografias do grupo instrumentação rotatória grupo

ProTaper - hipoclorito de sódio 1\%. Terço apical.
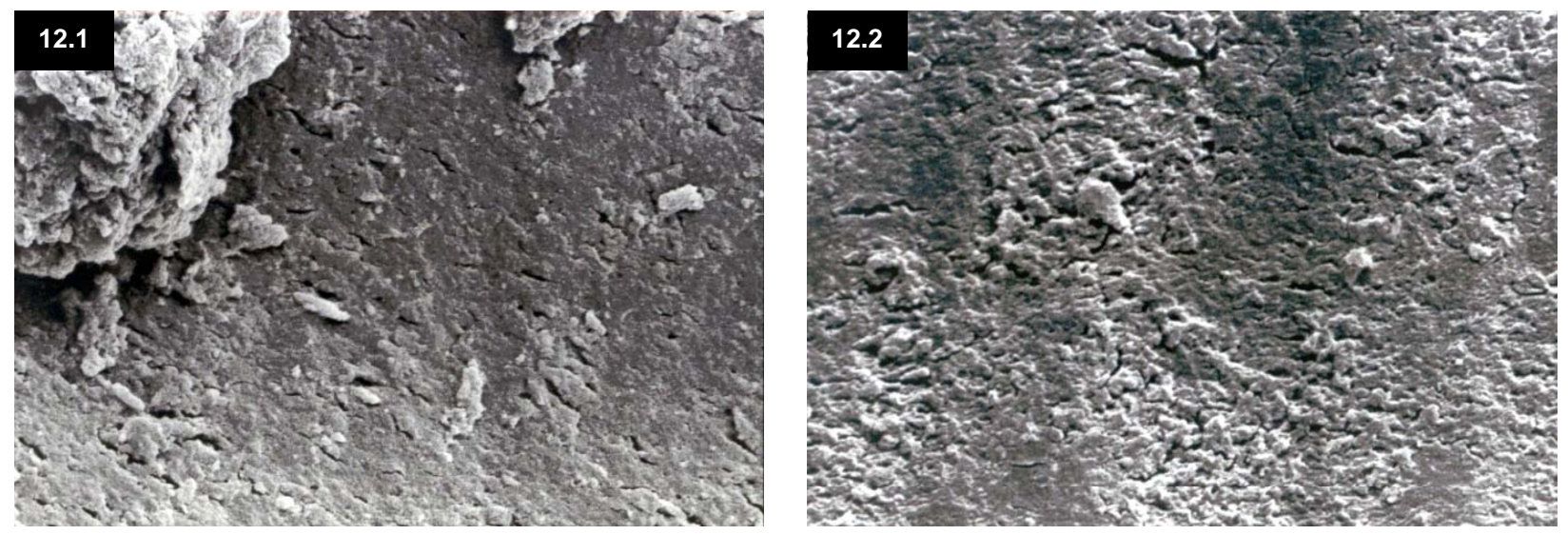
Anexo 13 - Fotomicrografias do grupo instrumentação rotatória grupo RaCe ${ }^{\circledR}$ - clorexidina 0,12\%. Terço médio.
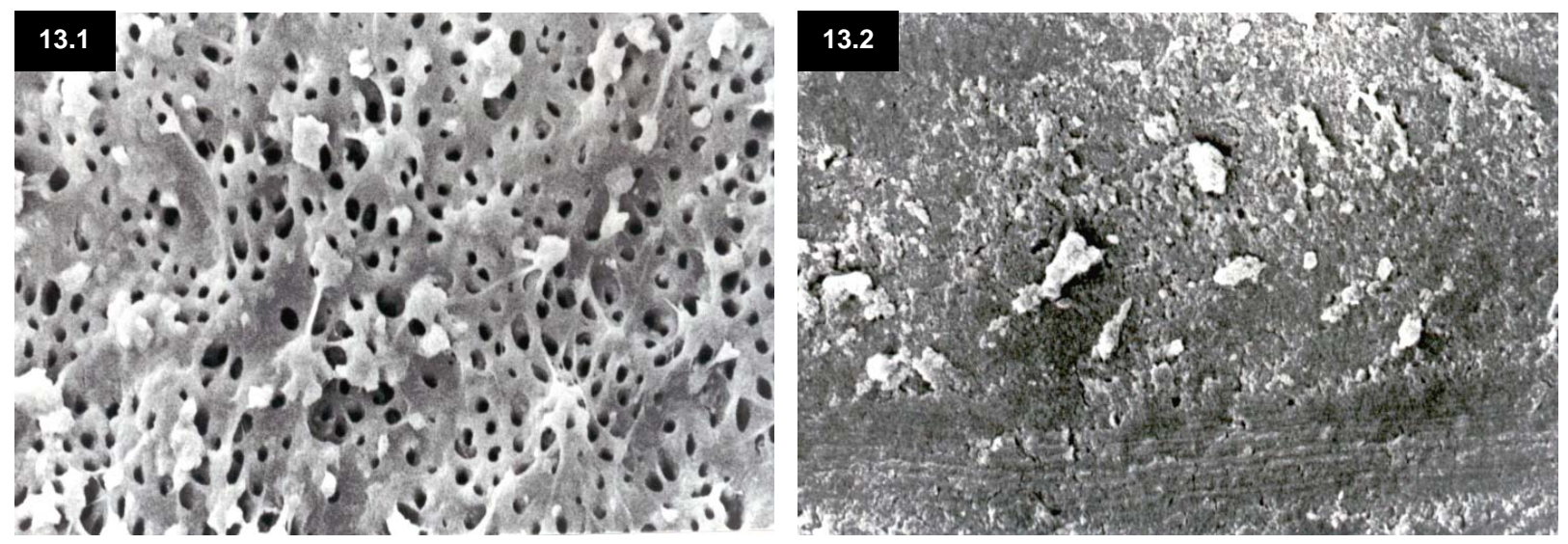

Anexo 14 - Fotomicrografias do grupo instrumentação rotatória grupo $\mathrm{RaCe} \circledast$ - clorexidina $0,12 \%$. Terço apical.
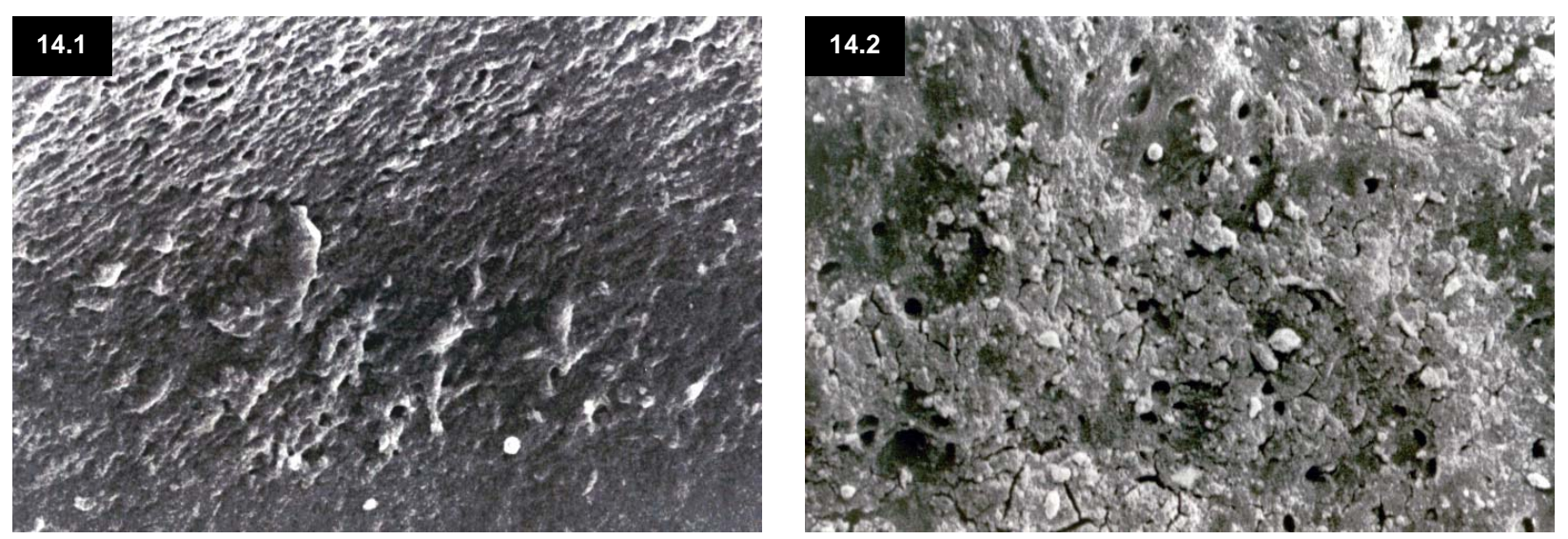
Anexo 15 - Fotomicrografias do grupo instrumentação rotatória grupo $\mathrm{RaCe} \circledast$ - hipoclorito de sódio 1\%. Terço médio.
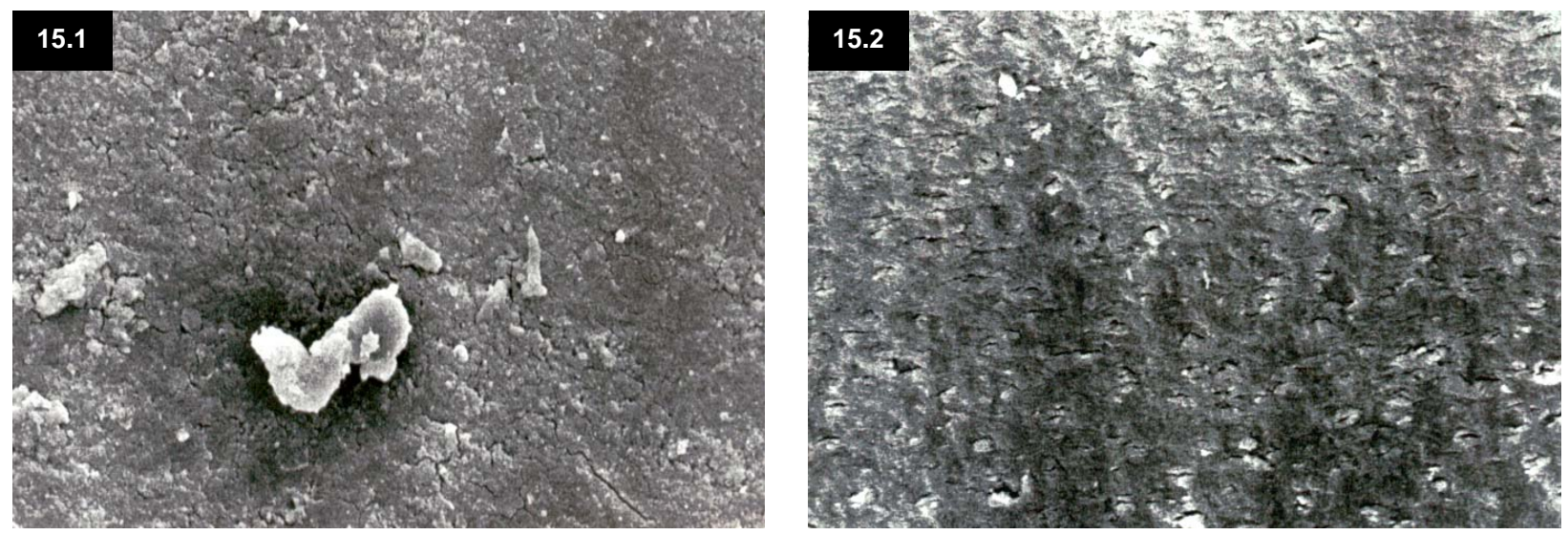

Anexo 16 - Fotomicrografias do grupo instrumentação rotatória grupo RaCe ${ }^{\circledR}$ - hipoclorito de sódio 1\%. Terço apical.
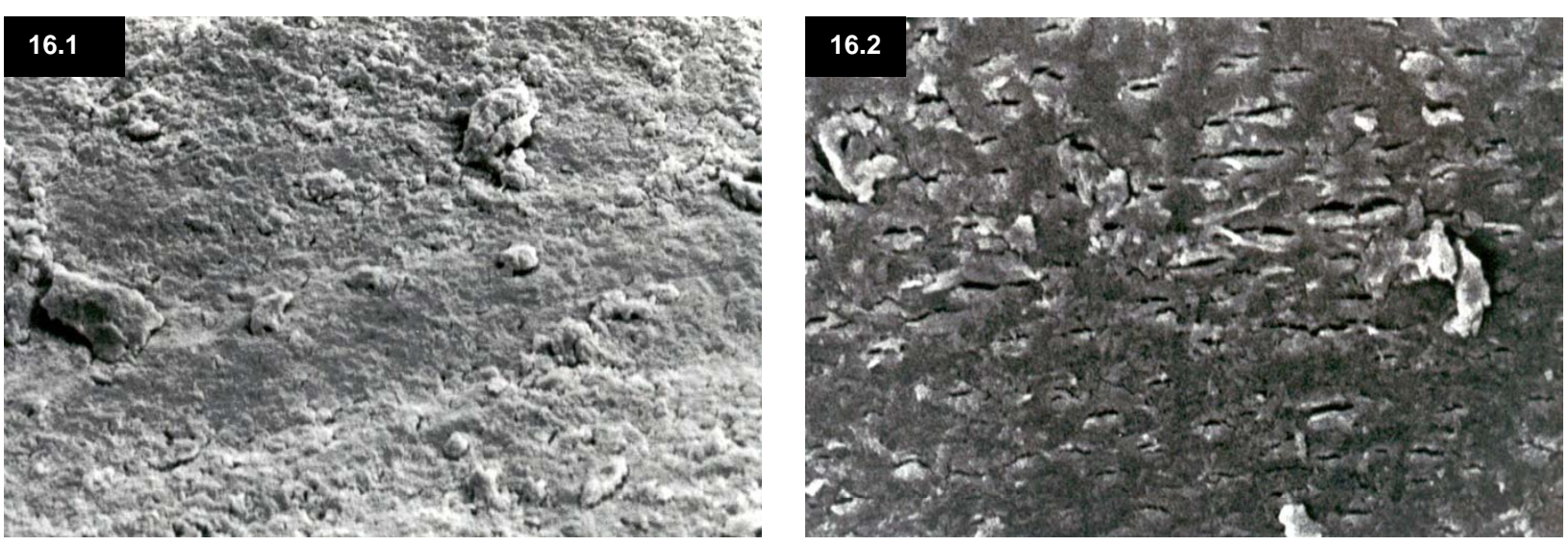
Anexo 17 - Fotomicrografias do grupo instrumentação rotatória grupo $\mathrm{K}^{3} \circledR$ - clorexidina 0,12\%. Terço médio.
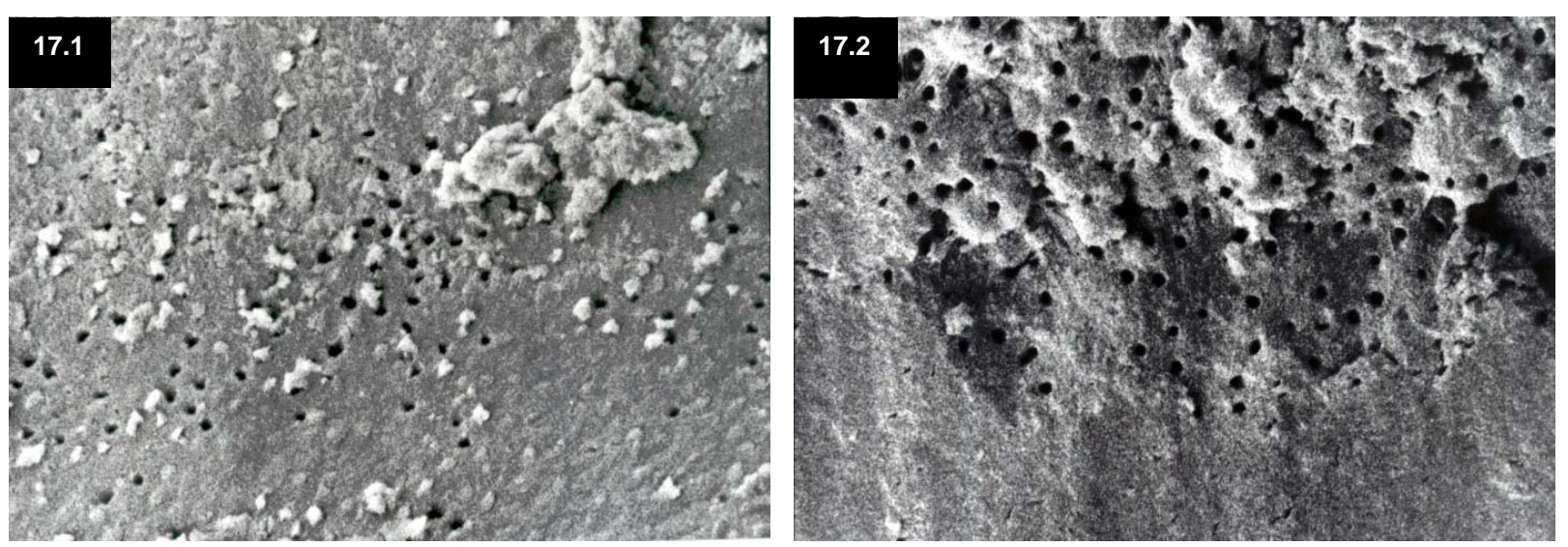

Anexo 18 - Fotomicrografias do grupo instrumentação rotatória grupo $\mathrm{K}^{3} \circledR$ - clorexidina $0,12 \%$. Terço apical.
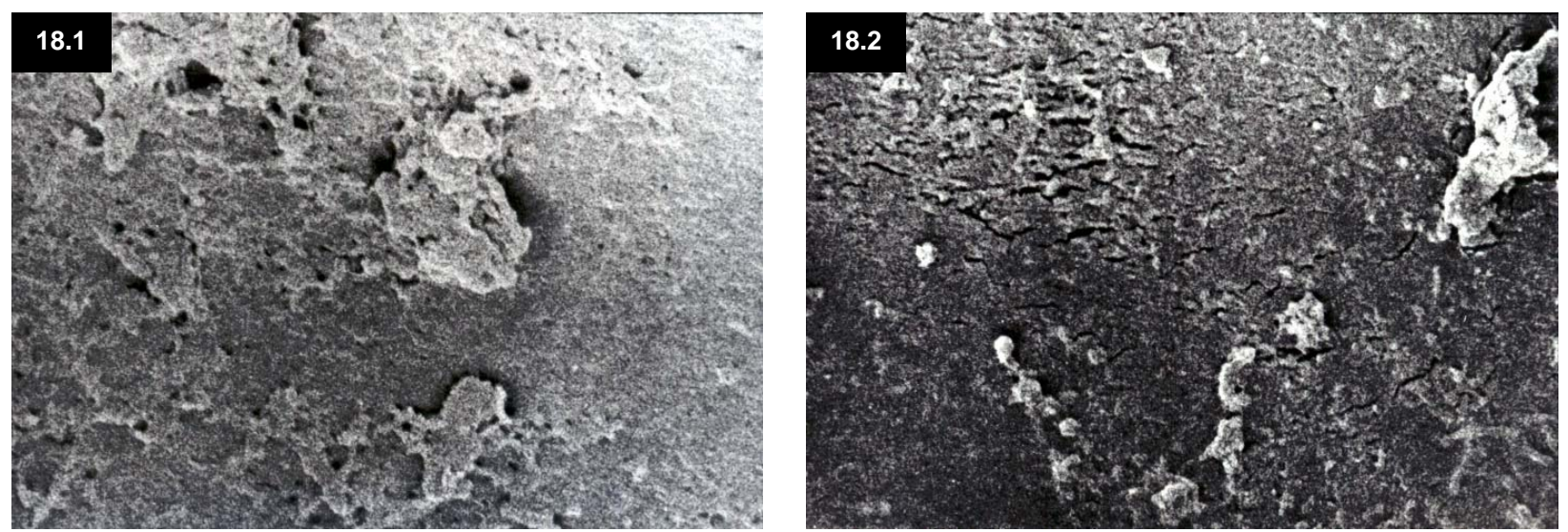
Anexo 19 - Fotomicrografias do grupo instrumentação rotatória grupo $\mathrm{K}^{3} \circledR$ - hipoclorito de sódio 1\%. Terço médio.
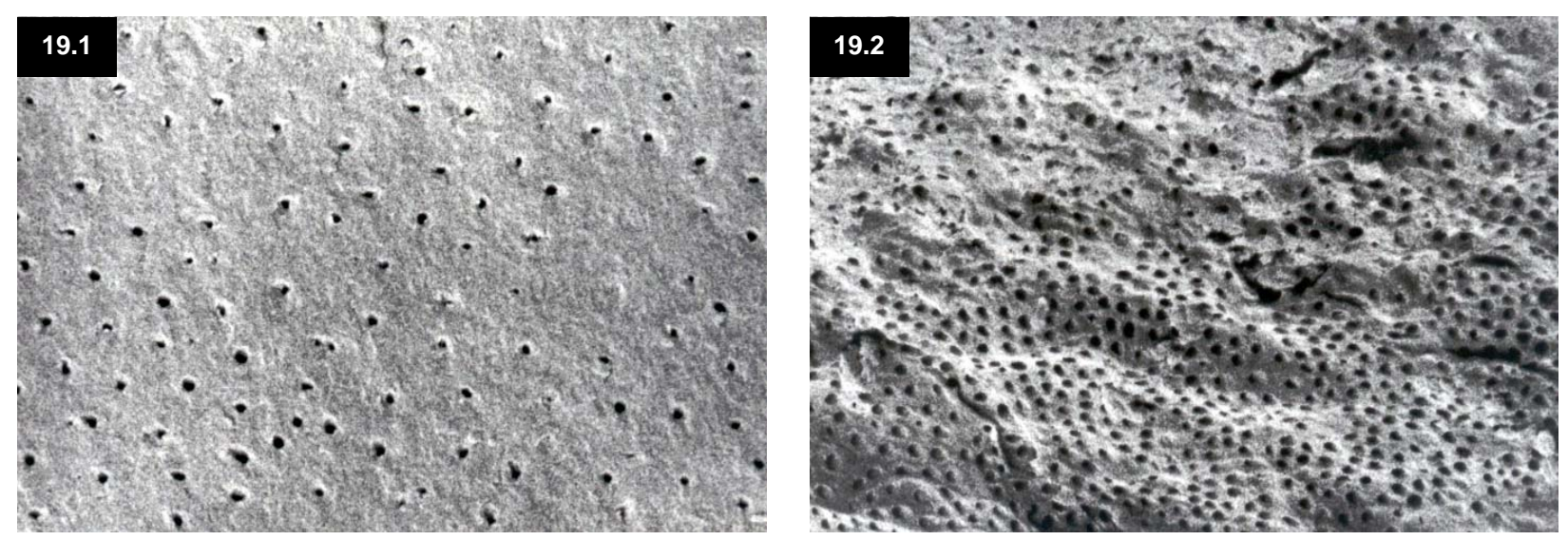

Anexo 20 - Fotomicrografias do grupo instrumentação rotatória grupo $\mathrm{K}^{3} \circledR$ - hipoclorito de sódio $1 \%$. Terço apical.
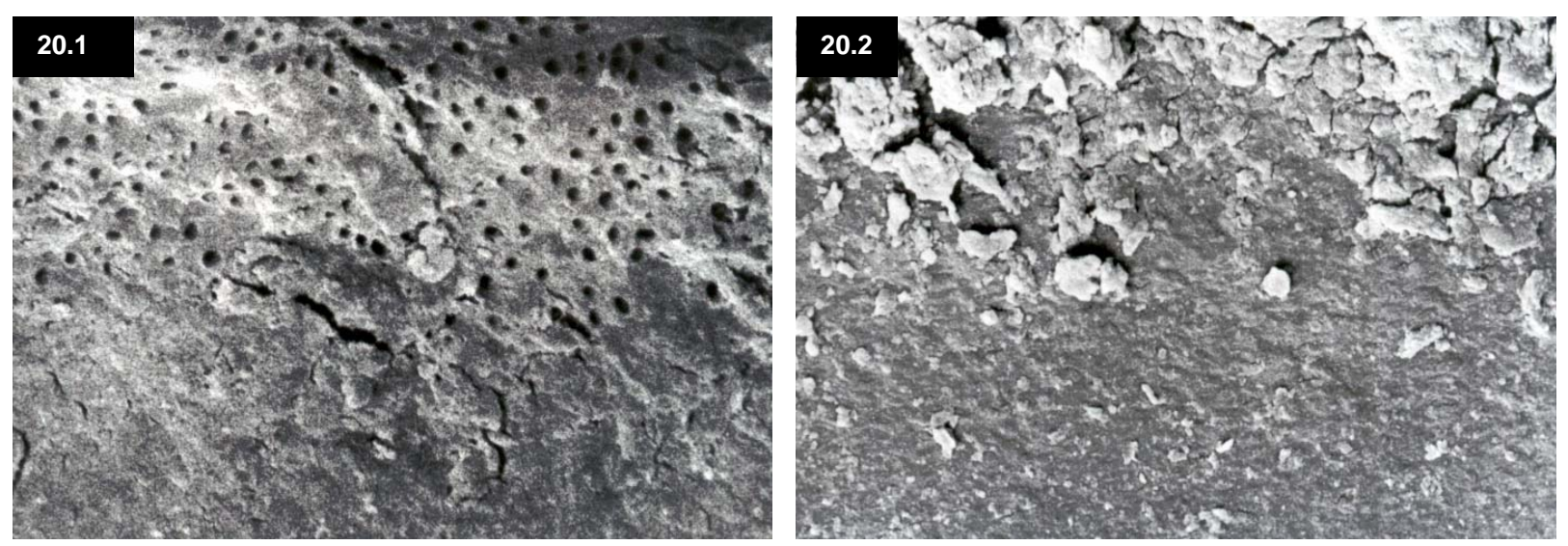
Anexo 21 - Fotomicrografia do grupo instrumentação manual-mecânico EDTA 17\%. Terço médio e apical, respectivamente.
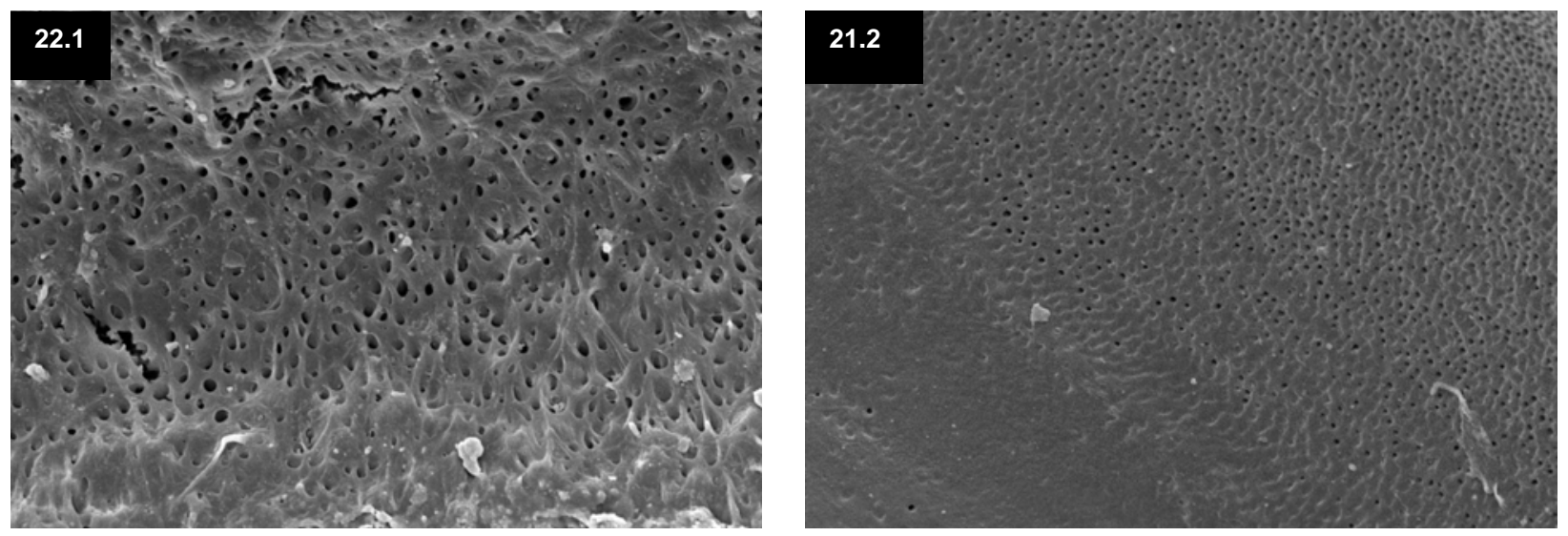

Anexo 22 - Fotomicrografia do grupo instrumentação manual-mecânico água destilada. Terço médio e apical, respectivamente.
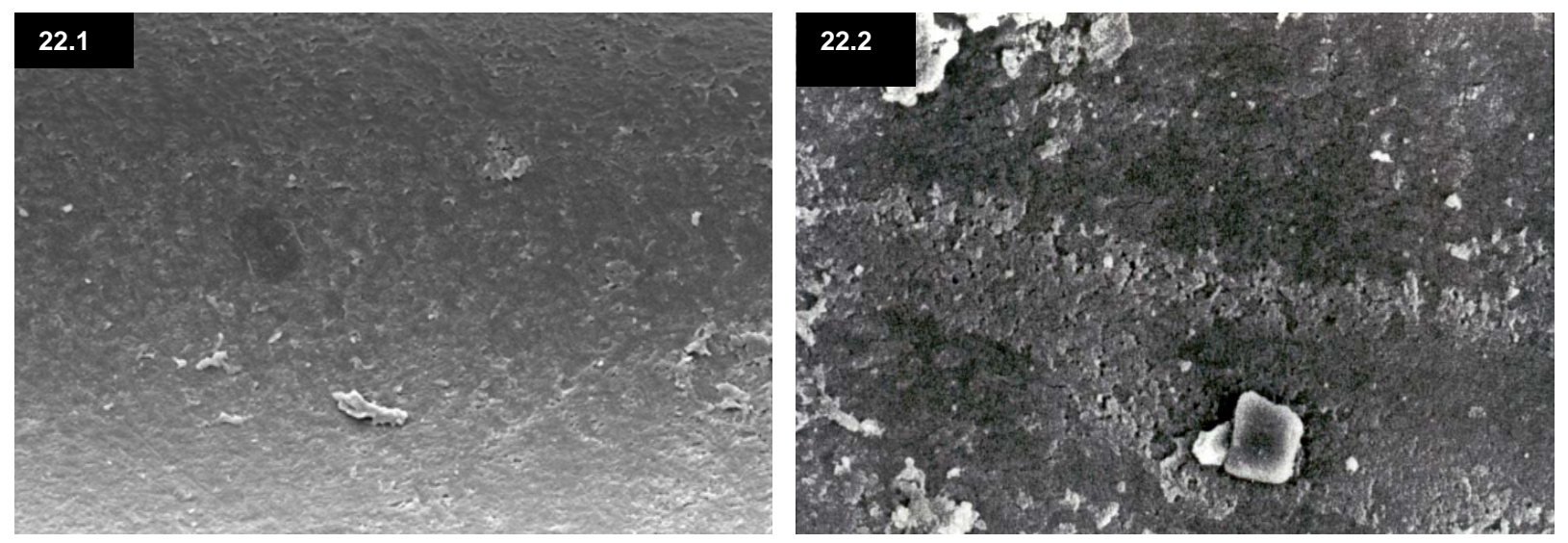

Anexo 23 - Fotomicrografia do grupo sem qualquer procedimento. Terço médio e apical, respectivamente.
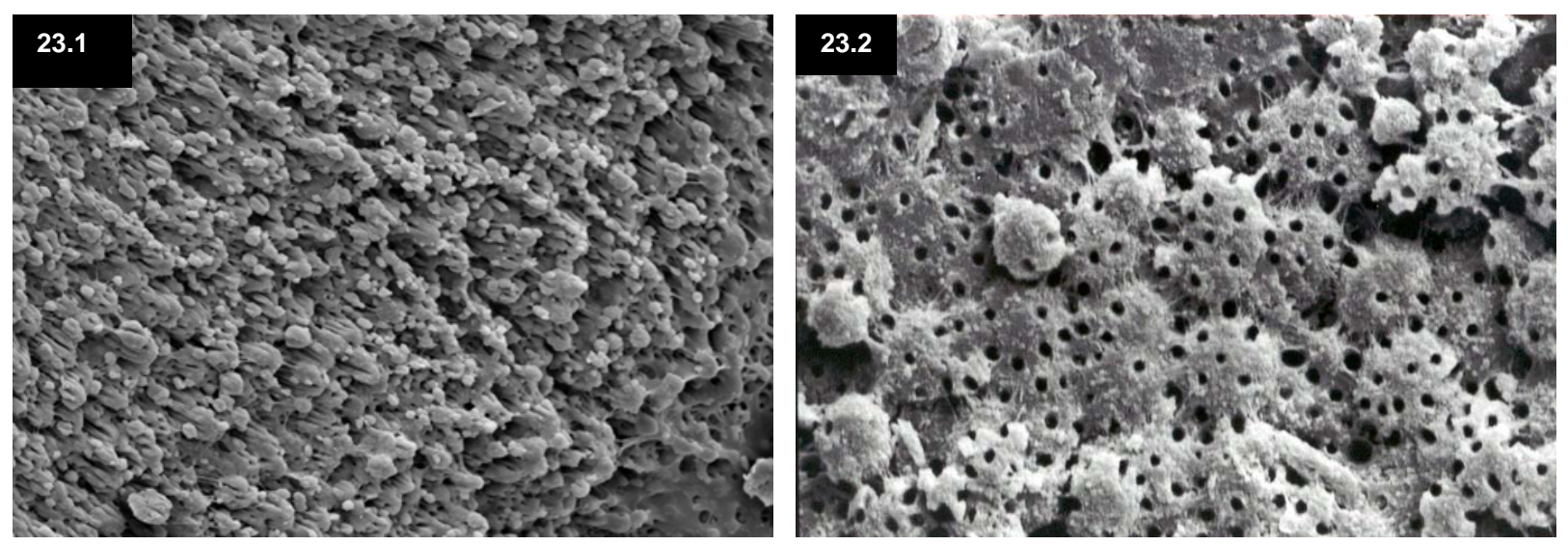

Rogério Emílio de Souza 


\section{REFERÊNCIAS BIBLIOGRÁFICAS ${ }^{1}$}

1. ABOU-RASS, M.; JASTRAB, R.J. The use of rotary instruments as auxiliary aids to root canal preparation of molars. J Endod, Baltimore, v. 8, n. 2, p. 78-82, Feb.1982.

2. ABOU-RASS, M.; OGLESBY, S.W. The effects of temperature, concentration and tissue type on the solvent abillity of sodium hypochlorite. J Endodon, Baltimore, v.7, n.8, p.376-377, Aug. 1981.

3. ADAMS, D.; ADDY, M. Mouthrinses. Adv Dent Res, Washington, v.8, n.2, p.291-301, Jul. 1994.

4. ALLISON, D.A.; WEBER, C.R.; WALTON, R.E. The influence of the method of canal preparation on the quality of apical and coronal obturation. J Endodon, Baltimore, v.5, n.10, p.298-304, Oct. 1979.

5. ALTANNIR, M.A.; GOODMAN, H.S. A review of chlorhedine and its use n special populations. Spec Care Dentist, Chicago, v.14, n. 3, p. 116-122, May-Jun. 1994.

6. AMARAL, G.; LOPES, H.P.; BOMBONA, A.C.; ELIAS, C.N. Avaliação da capacidade de corte de limas tipo $\mathrm{K}$ de aço inoxidável e de níquel-titânio. JBE, Curitiba,v.4n.1,p.223-230, jan/fev/mar.2003.

7. AMERICAN ASSOCIATION OF ENDODONTICS. Glossary: Contemporary Terminology for Endodontics, 6 th edn. Chicago, IL, USA:American Asociation of Endodontics.

8. ATTIN, T.; BUCHALLA, W.; ZIRKEL, C.; LUSSI, A. Clinical evaluation of the cleansing properties of the noninstrumental technique for cleaning root canals. Int Endod J, London, v.35, n.11, p.929-933, Nov. 2002.

9. AUN, C.E. Análise "in vitro", através da microscopia eletrônica de varredura, da quantidade de canalículos dentinários livres da camada residual de magma no terço apical do canal radicular, após preparo químico-mecânico, variando-se o instrumento e seu número de uso. São Paulo, 1990. 67p. Tese (Livre-Docência

\footnotetext{
${ }^{1}$ Normas recomendadas para o uso no âmbito da Universidade de São Paulo com base no documento "Referências Bibliográficas", emanado do Conselho Supervisor do Sistema Integrado de Bibliotecas da USP em reunião de 20 de setembro de 1990.
} 
em Endodontia). Faculdade de Odontologia de São Paulo, Universidade de São Paulo.

10. AUN, C.E. Avaliação, através da microscopia eletrônica de varredura, da limpeza da parede do canal radicular (Terço apical), após o preparo químico-mecânico, tendo como fonte de variação o tipo e o número de uso dos instrumentos. São Paulo, 1985. 73p.Tese (Doutorado em Endodontia). Faculdade de Odontologia de São Paulo, Universidade de São Paulo.

11. AUN. C.E. Possíveis variações do efeito antimicrobiano de uma solução de hipoclorito de sódio em função da concentração, tempo de contacto e da experimentação com e o uso de instrumentos endodôntico. São Paulo, 1979. 64p. Dissertação (Mestrado em Endodontia). Faculdade de Odontologia de São Paulo, Universidade de São Paulo.

12. AUN, C.E.; PAIVA, J.G.; ANTONIAZZI, J.H. Avaliação, através da microscopia eletrônica de varredura, da limpeza da parede do canal radicular (terço apical), após o preparo químico-mecânico, tendo como fonte de variação o tipo e o número de uso de instrumentos. Rev APCD, São Paulo, v.44, n.1, p.13-17, jan/fev.1990.

13. BAKER, N.A.; ELEAZER, P.D.; AVERBACH, R.E.; SELTZER, S. Scanning electron microscopic study of the efficacy of various irrigating solutions. J Endodon, Baltimore, v.1, n.4, p.127-135, Apr. 1975.

14. BARATO FILHO, F. Estudo in vitro da capacidade de limpeza do canal radicular através de instrumentação rotatória e irrigação com hipoclorito de sódio em três diferentes concentrações: análise histológica. 2002. 66p. Dissertação (Mestrado em Endodontia) - Faculdade de Odontologia,Universidade de Ribeirão Preto, Ribeirão Preto.

15. BARATO FILHO, F.; CARVALHO Jr, J.R.; FARINIUK, L.F.; SOUSANETO, M.D.; PÉCORA, J.D.; CRUZ-FILHO, A.M. Morphometric 
analysis of the effectiveness of different concentrations of sodium hypochlorite associated with rotary instrumentation for root canal cleaning. Braz Dent J, Ribeirão Preto, v.15, n.1, p.36-40, 2004.

16. BARBIZAM, J.V.B.; FARINIUK, L.F.; MARCHESAN, M.A.; PÉCORA, J.D.; SOUSA-NETO, M.D. Effectinveness of manual and rotary instrumentation techniques for cleaning flattened root canals. J Endodon, Baltimore, v.28, n.5, p.365-366, May. 2002.

17. BARDAL, P.A.P. Avaliação dos Efeitos de Dentifrícios Contendo Clorexidina sobre o Desenvolvimento de Placa Dentária, Gengivite, Cálculo e Manchamento Extrínseco do Esmalte Dentário em Pacientes sob Tratamento Ortodôntico. 2005. 102p. Dissertação (Mestrado em Odontologia), Faculdade de Odontologia de Bauru, Universidade de São Paulo.

18. BARRETT, M.T. The Dakin carrel antiseptic solution. Dental Cosmos, Philadelphia , v.59, n.4, p.446-448, Apr. 1917.

19. BAUMGARTNER, J.C.; CUENIN, P.R. Efficacy of several concentrations of sodium hypochlorite for root canal irrigation. J Endodon, Baltimore, v.18, n.12, p.605-612, Dec. 1992.

20. BAUMGARTNER, J.C.; MADER, C.L. A scanning electron microscopic evaluation of four root canal irrigation regimes. Int Endod J, London, v. 13, n. 4, p.147-157, April. 1987.

21. BERBERT, A.; BRAMANTE, C.M.; BERNARDINELI, N. Endodontia Prática, São Paulo:Sarvier, 1980.

22. BERBERT, A. et al. Técnica de Oregon modificada. RGO, Porto Alegre, v. 44, n. 3, p.141-142, maio/jun.1996.

23. BERGMANS, L.; Van CLEYNENBREUGEL, J.; WEVERS, M.; LAMBRECHTS, P. Mechanical root canal preparation with NiTi rotatory instruments: rationale, performance and safety. Status report for the American Journal of Dentistry. Am J Dentistry, v. 14, n. 5, 324-333, Oct.2001.

24. BERGMANS, L.; Van CLEYNENBREYGEL, J.; BEYLLENS, M.; WEVERS, M.; Van MEERBEEK, B.; LAMBRECHTS, P. 
Progressive versus constant taperede shaft design using NiTi rotary instruments. Int Endod J, London, v.36, n.4, p.288-295, April. 2003.

25. BOLANOS, O.R.; JENSEN, F.R. Scanning electron microscope comparisons of the efficacy of various methods of root canal preparation. J Endodon, Baltimore, v. 6, n. 11, p.815-822, Nov.1980.

26. BUCK, R.A.; ELEAZER, P.D.; STAAT, R.H.; SCHEETZ, J.P. Effectinveness of three endodontic irrigants at various tubular depths in human dentin. J Endodon, Baltimore, v.27, n.3, p.206208, Mar. 2001.

27. CALBERSON, F.L.G; DEROOSE, C.A.J.G.; HOMMEZ, G.M.G.; De MOOR, R.J.G. Shaping ability of ProTaper nickel-titanium files in simulated resin root canals. Int Endod J, London, v. 37, n. 9, p.613-623, Sept. 2004

28. CALLAHAN, J.R. Sulfuric acid for opening root-canals. Dental Cosmos, Philadelphia, v.36, n.12, p.957-959, Dec. 1894.

29. CAMPS, J.; PERTOT, W.J. Machining efficientcy of nickel-titanium Ktype files in a linear motion. Int Endod J, London, v. 28, n. 6, p.279-284, Nov.1995.

30. CAPELLI, A.; SEIXAS, F.H.; PÉCORA, J.D. Isntrumentação rotatória eletromecânica dos canais radiculares. RGO, Porto Alegre, v.50, n.2, p.89-92, abr./maio/jun. 2002.

31. CHAVES, M. Avaliação, por meio de microscopia eletrônica de varredura, da presença de detritos nos canais radiculares instrumentados com os géis de clorexidina e de mamona. Ribeirão Preto, 2002, 90p. Dissertação (Mestrado em Endodontia) Faculdade de Odontologia de Ribeirão Preto, Universidade de São Paulo.

32. CHENAIL, B.L.; TEPLITSKY, P.E. Endosonics in curved root canals. J Endodon, Baltimore, v. 11, n. 9, p.369-374, Sept.1985. 
33. CHEUNG, G.S.P.; STOCK, J.R. In vitro cleaning ability of root canal irrigants with and without endosonics. Int Endod J, London,v. 26, n. 6, p.334-343, Nov.1993.

34. Clauder, T.; BAUMANN, M.A. Protaper NT system. Dent Clin North Am, Philadelphia, v. 48, n. 1, p.87-111, Jan.2004

35. CLEM, W.H. Endodontics: The adolescent patient. Dent Clin North Am, Philadelphia, v. 13, n. 2, p. 483-493, Apr.1969.

36. COFFAE, K.P.; BRILLIANT, J.D. The effect of serial preparation versus non serial preparation on tissue removal in root canals of extracted mandibular human molars. J Endodon, Baltimore, v.1, n.6, p.211-214, June.1975.

37. COSTA, C.A.S.; HEBLING, J.; D'ABREU, M.C.F.; RACHED, R.N.; MONTANO, T.C.P. Efeito da clorexidina 0,2\% sobe o complexo dentino-pulpar quando aplicada em associação com o sistema adesivo Scotchbond MP em molares de ratos. Robrac, v.8, n.25, p.4-9, ago. 1999.

38. CRUZ FILHO, A.M.; SOUSA-NETO, MD; SAQUY, P.C.; PÉCORA, J.D. Evalution of the effect of EDTAC, EDTA and EGTA on radicular dentin microhardness. J Endodon, Baltimore, v.27, n.3, p.183-84, March 2001.

39. DAKIN, H.D. In the use of certain antiseptic substances in the treatment of infected wounds. British Medial Journal, London, v.2, n.2, p.318-20, 1915.

40. DAVIES, R.M.; JENSEN, S.B.; SCHIOTT, C.R.; LOE, H. The effect of topical application of chlorhexidine on the bacterial colonization of the teeth and gingival. J Periodontal Res, Chigado, v.5, n. 2, p.96-101, 1970.

41. De DEUS, G.A.; GURGEL FILHO, E.D.; COUTINHO FILHO, T.; LOPES, M.F.S. Avaliação do grau de limpeza obtido por duas técnicas de instrumentação. Rev Bras Odont, Rio de Janeiro, v.57, n.6, p.354-358, nov./dez. 2000. 
42. DELANY, G.M.; PATTERSON, S.S.; MILLER, C.H.; NEWTON, C.W. The effect of chlorhexidine gluconate irrigation on the root canal flora of freshly extracted necrotic teeth. Oral Surg Oral Med Oral Pathol Oral Radiol Endod, St Louis, v. 53, n.5, p.518-523, May.1982.

43. ESTRELA, C.; FIGUEIREDO, J.A.P. Preparo do canal radicular. In:___ Endodontia: Princípios biológicos e mecânicos. São Paulo:Artes Médicas; 1999. p. 493-549.

44. EUROPEAN SOCIETY OF ENDODONTOLOGY. Consensus report of the European Society of Endodontology on quality guidelines for endodontic treatment. Int Endod J, London, v. 27, n. 3, p.115-124, May.1994.

45. FACHIN, E.V.F.; HAHN, L.; PALMINI, A.L.F. Revisão e enfoque clínico sobre o uso do hipoclorito de sódio em Endodontia. Rev Bras Odont, São Paulo, v.51, n.6, p.14-17, nov./dez. 1994.

46. FARDAL, O.; TURNBULL, R.S. A review of the literature on use of chlorhexidine in dentistry. J Am Dent Assoc, Chicago, v. 112, n. 6, p. 863-869, Jun.1986.

47. FAVA, L.R.G. The double-flared technique: an alternative for biomechanical preparation. J Endodon, Baltimore, v. 9, n. 2, p. 76-80, Feb.1983.

48. FAVA, L.R.G.; CONDE, M.C.; SIQUEIRA Jr, J.F. Emprego endodôntico da clorexidina: Perspectivas atuais e futuras. J Bras Clin Odontol Int, Curitiba, v.5, n.30, p.s478-485, nov/dez.2001.

49. FERGUSON, D.B.; MARLEY, J.T.; HARTWELL, G.R. The effect of chlorhexidine gluconate as an endodontic irrigant on the apical seal: long-term results. J Endodon, Baltimore, v.29, n.2, p.91-94, Feb. 2003.

50. FERRAZ, C.C., GOMES,B.P.F.A; ZAIA, A.A.; TEIXEIRA, F.B. SOUZA FILHO, F.J. In vitro assessment of the antimicrobial action and mechanical ability of chlorhexidine gel as an endodontic irrigant. J Endodon, Baltimore, v. 27, n. 7, p.452-455, July.2001. 
51. FOSCHI, F.; NUCCI, C.; MONTEBUGNOLI, L.; MARCHIONNI, S.; BRESCHI, L.; MALAGNINO, A.; PRATI, C. SEM evaluation of canal wall dentine following use of Mtwo and ProTaper NiTi rotary instruments. Int Endod J, London, v. 37, n. 12, p. 832-839, Dec.2004.

52. FRÖNER, I.C. Avaliação comparativa da limpeza do terço apical de pré-molares inferiores após instrumentação manual e ultra-sônica utilizando diferentes soluções irrigantes. Análise por microscopia eletrônica de varredura. Ribeirão Preto. 2003. 139p. Tese (Livre Docência) - Faculdade de Odontologia de Ribeirão Preto, Universidade de São Paulo.

53. GALVAN, D.A.; CIARLONE, A.E.; PASHLEY, D.H.; KULILD, J.C.; PRIMACK, D.D.; SIMPSON, M.D. Effect of smear layer removal on the diffusion permeability of human roots, $\mathbf{J}$ Endodon, Baltimore,v.20, n.2, p.83-86, Feb. 1994.

54. GAMBARINI, G. Shaping and cleaning the root canal system: a scanning electron microscopic evaluation of a new instrumentation and irrigation technique. Int Endod J, London, v. 25, n.12, p. 800803, Dec.1999.

55. GAMBARINI, G.; LASZKIEWICZ, J. A scanning electron micoscopic study of debris and smear layer remaining follwing use of GT rotary instruments. Int Endod J, London, v.35, n.5, p.422-427, May. 2002.

56. GARCIA FILHO, P.F.; SANTOS, L.L.C.; CARVALHO, K.B.S., MENEZES, R.; LETRA, A.M.G. Cleaning ability of rotary instruments in the apical third of curved molars. Rev Fac Odontol Bauru, Bauru, v. 10, n.4, p.253-256, out/dez. 2002.

57. GAVINI, G.; AUN, C.E.; PESCE, H.F. Análise das condições de limpeza do terço apical do canal radicular após o preparo químicomecânico. Rev Odontol USP, São Paulo, v.8, n.3, p.155-162, jul/set.1994. 
58. GOERIG, A.C.; MICHELICHI, R.J.; SCHULTZ, H.H. Instrumentation of root canals in molar using the step-down technique. J Endodon, Baltimore, v.8, n. 12, p. 550-554, Dec.1982.

59. GOLDMAN, L.B.; GOLDMAN, M.; KRONMAN, J.H.; LIN, P.S. The efficacy of several irrigation solutions for endodontics a scanning electron microscopic study. Oral Surg Oral Med Oral Pathol, St. Louis, v.52, n.2, p.197-204, Aug.1981.

60. GOLDSMITH, M.; GULABIVALA, K.; KNOWLES, J.C. The effect of sodium hypochlorite irrigant concentration on tooth surface strain. J Endodon, v.28, n.8, p.575-579, Aug. 2002.

61. GONÇALVES Jr, F.F. Análise comparativa entre o sistema Profile 0,04/0,06 e a técnica Oregon Modificada na remoção de corante aderido às paredes de canais radiculares achatados. Bauru, 2003. 98p. Dissertação (Mestrado em Endodontia). Faculdade de Odontologia de Bauru, Universidade de São Paulo.

62. GONÇAVES, S.B.; BROSCO, V.H.; BRAMANTE, C.M. Análise comparativa entre instrumentação rotatória (GT), manual e associação de ambas no preparo de canais achatados. J Appl Oral Sci, Bauru, v.11, n.1, p.35-39, Jan/March. 2003.

63. GORDON, T.M.; DAMATO, D.; CHRISTNER, P. Solvent effect of various dilutions of sodium hypochlorite on vital and necrotic tissue. J Endod, Baltimore, v. 7, n. 10, p. 466-469, Oct.1981.

64. GRANDINI, S.; BALLERI, P.; FERRARI, M. Evaluation of Glyde File Prep in combination with sodium hypochlorite as a root canal irrigant. J Endod, Baltimore, v, 28, n. 4, p. 300-303, Apr.2002.

65. GRECCA, F.S. Avaliação da eficácia dos métodos de instrumentação rotatória (Sistema $\mathrm{K}^{3}$ e ProTaper), ultra-som e manual na remoção de corante aderido às paredes de canais radiculares com achatamento proximal. Estudo "in vitro". Bauru, 2003. 143p. Tese (Doutorado em Endodontia). Faculdade de Odontologia de Bauru, Universidade de São Paulo. 
66. GREENSTEIN, G.; BERMAN, C.; JAFFIN, R. Chlorhexidine. An adjunct to periodontal therapy. J Periodontol, Chicago, v. 57, n. 6, p. 370-377, June.1986.

67. GROSSMAN, L.I.; MEIMAN, B.W. Solution of pulp tissue by chemical agents. J Am Dent Assoc, Chicago, v.28, n.2, p.223-5, Feb. 1941.

68. HAIKEL, Y.; ALLEMAN, C. Effectiveness of four methods for preparing root canals: a scanning electron microscopic evaluation. J Endodon, Baltimore, v. 14 n. 7, p. 340-345,July.1988

69. HAND, R.E.; SMITH, M.L. HARRISON, J.W. Analysis of the effect of dilution on the necrotic tissue dissolution property of sodium hypochlorite. J Endodon, Baltimore, v. 4, n. 2, p. 60-64, Feb.1978.

70. HEARD, D.D.; ASWORTH, R.W. The colloidal properties of chlorhexidine and its interaction with some macromolecules. J Pharm Pharmacol, v.20, n.7, p.505-512, July.1968.

71. HENESSEY, T.D. Some bacterial properties of chlorhexidine. J Periodontal Res, Chicago, v. 8, p.61-67, 1973.

72. HODGE, H.C.; McKAY, H. The microhardness of teeth. J Am Dent Assoc, Chicago, v. 20, n. 2, p. 227, 1933.

73. HOLLAND, R., SOUZA, V., OTOBONI FILHO, J.A., NERY, M.J., BERNABÉ, P.F.E., MELLO, W. Técnicas mistas de preparo do canal radicular. Rev Paul Odontol, São Paulo, v.13, n. 4, p.1723, Jul/Ago.1991.

74. HÜLSMANN, M.; RÜMMELIN, C.; SCHÄFERS, F. Root canal cleanliness after preparation with different endodontic handpieces and hand instruments: a comparative SEM investigation. J Endodon, Baltimore, v. 23, n. 5, p. 301-306, May.1997.

75. INGLE, J.; ZELDOW, B.J. An evalution of mechanical instrumentation and the negative culture in endodontic therapy. J Am Dent Assoc, Chicago, v.57, n.4, p.471-476, Oct. 1958.

76. JEON, I.S.; SPÄNBERG, L.S.W., YOON, T.C., KAZEMI, R.B.; KUM, K.Y. Smear layer production by 3 rotary reamers with different 
cutting blade desing in straight root canals: a scanning electron microscopic study. Oral Surg Oral Med Oral Pathol Oral Radiol Endod, St Louis, v. 96, n. 5, p. 601-607, Nov.2003.

77. KIRK, E.C. Sodium peroxid $\left(\mathrm{Na}_{2} \mathrm{O}_{2}\right)$. A new dental bleaching agent and antiseptic. Dental Cosmos, Philadelphia, v.35, n.2, p.192198, Feb. 1893.

78. LIM, T.S.; WEE, T.Y.; CHOI, M.Y.; KOH, W.C.; SAE-LIM, V. Light and scanning electron microscopic elvaluation of Glyde ${ }^{T M}$ File Prep in smear layer removal. Int Endod J, London, v. 36, n. , p.336-343, 2003.

79. LOE, H.; SCHIOTT, C.R. The effect of mouthrinses and topical application of chlorhexidine on the development of dental plaque and gengivites in man. J Periodontal Res, Chicago, v.5, n. 2, p.79-83, 1970.

80. LOE, H, SCHIOTT, C.R.; KARRING, G.; KARRING, T. Two year's oral use of chlorhexidine in man. I. eneral design and clinical effects. $\mathbf{J}$ Periodontal Res, Chicago, v.12, n.7, p.135-144, June.1976.

81. LOPES, H.P.; ELIAS, C.N.; ESTRELA, C.; FONTES, P.P.; TUCHMAN, D. Emprego de limas acionadas a motor no preparo de canais radiculares. RBO, Rio de Janeiro, v. 53, n. 3, p. 20-24, set/out. 1996.

82. LOPES, H.P.; SIQUEIRA Jr, J.F.; ELIAS, C.N. Substâncias químicas empregadas no preparo dos canais radiculares. In:

Endodontia: Biologia e Técnica. 2.ed.Rio de Janeiro: Medsi, 2004. p. 535-579.

83. LOPES, H.P.; ELIAS, C.N.; SIQUEIRA Jr, J.F. Instrumento Endodônticos. In: . Endodontia: Biologia e Técnica. 2.ed. Rio de Janeiro:Guanabara Koogan, 2004. p. 323-417.

84. MANIGLIA, C.A.G.; BIFFI, J.C.G. Avaliação do volume do canal radicular após as instrumentações manual e ultrassônica. Rev APCD, São Paulo, v. 49, n. 4, p. 291-294, Jul/Ago.1995. 
85. MARCANO, P.B.; MARTÍNEZ-BERNÁ, A. Preparación quirúrgica de los conductos radiculares. Rev Esp Endod, v.15, n. 9, p. 417-421, Sept.1983.

86. MARCHESAN, M.A.; ARRUDA, M.P.; SILVA-SOUSA, Y.T.C.; SAQUY, P.C.; PÉCORA, J.D. SOUSA-NETO, M.D. Morphometrical analysis of cleaning capacity using nickel-titanium rotary instrumentation associated with irrigating solutions in mésio-distal flattened root canals. J Appl Oral Sci, Bauru, v.11, n.1, p.55-59, Jan/March. 2003.

87. MARSHALL, F.J. PAPPIN, J.B. Técnica de Oregon. Ind: De DEUS, Q.D. Endodontia. 5 ed. Rio de Janeiro, Medsi, 1992, 337p.

88. MARTIN, H. A. A telescop technic for endodontics. J Dent Columbia Soc, v. 49, n. 2, p. 12-19, 1974.

89. MAYER, B.E.; PETERS, O.A.; BARBAKOW, F. Effects of rotary instruments and ultrasonic irrigation on debris and smear layer scores: a scanning electron microscopic study. Int Endod J, London, v.35, n.7, p.582-589. July. 2002.

90. McCLELLAND, J.R.; WASS, M.J. A contribution to the study of the chlorin disinfectants. Dental Cosmos, Philadelphia, v.64, n.1, p.56-66, Jan. 1922.

91. MORGAN, L.F.; MONTGOMERY, S. An evaluation of the crown-down pressureless technique. J Endodon, Baltimore, v. 10, n. 10, p. 491-498, Oct.1984.

92. MOUNCE, R.E. The $K^{3} \circledast$ rotary nickel-titanium file system. Dent Clin North Amer, Philadelphia, v. 48, n. 12, p.137-157, Jan.2004.

93. MULLANEY, T.P. Instrumentation of finely curved canals. Dent Clin North Amer, Philadelphia, v.23, n. 4, p.575-592, Oct.1979.

94. NIU, W.; YOSHIOKA, T.; KOBAYASHI, C.; SUDA, H. A scanning electron microscopic study of dentinal erosion by final irrigation with EDTA and $\mathrm{NaOCl}$ solutions. Int Endod J, London, v.35, n.11, p.934-939, Nov. 2002. 
95. OLIVEIRA, M.R.B. Avaliação da eficiência de limpeza de algumas soluções irrigadoras sobre a dentina radicular, através de microscopia eletrônica de varredura. Bauru, 1982. 103p. Dissertação (Mestrado em Diagnóstico Oral)-Faculdade de Odontologia de Bauru, Universidade de São Paulo.

96. PAIVA, J.G.; J.H.; ANTONIAZZI, J.H.; ROBAZZA, C.R.C.; COSTA, W.F.; CARLIK, J.; ROMANI, N.F. Fase do preparo do canal radicular. In: __ Endodontia: bases para a prática clínica. São Paulo, Artes Médicas, 1988. p. 531-629.

97. PAQUÉ, F.; MUSCH, U.; HÜLSMANN, M. Comparison of root canal preparation using $\mathrm{RaCe}$ and ProTaper rotary $\mathrm{Ni}$-Ti instruments. Int Endod J, London, v. 38, n.1, p.8-16, Jan. 2005.

98. PASHLEY, D.H. Clinical considerations of microleakage. J Endodon, Baltimore, v.16, n.2. p.70-77, Feb. 1990.

99. PASHLEY, D.H.; TAO, L.; BOYD, L.; KING, G.E.; HORNER, J.A. Scanning electron microscopy of the substructure of smear layer in human dentine. Arch Oral Biol, Oxford, v.33, n.4, p.265-270, May 1988.

100. PASHLEY, E.L.; HONER, J.A; LIU, M.; KIM, S.; PASHLEY, D.H. Effects of $\mathrm{CO}_{2}$ laser energy on dentin permeability. J Endodon, Baltimore, v.18, n.6, p.257-262, Jun. 1992.

101. PATAKY, L.; IVÁNYI, I.; GRIGÁR, A.; FAZEKAS, A. Antimicrobial efficacy of various root canal preparation techiques: na In vitro comparative study. J Endodon, Baltimore, v.28, n.8, p.603-605, Aug. 2002.

102. PÉCORA, J.D.; MURGEL, C.A.F.; SAVIOLI, R.N.; COSTA, W.F.; VANSAN, L.P. Estudo sobre o shelf life da solução de Dakin. Rev Odont USP, São Paulo, v. 1, n. 1, p. 3-7, jan/mar.1987.

103. PETERS, O.A.; PETERS, C.I.; SCHÖNENBERGER, K.; BARBAKOW, F. ProTaper rotatory root canal preparation: effects of canal anatomy on final shape analysed by micro CT. Int Endod J, London, v.36, n.2, p.86-92, Feb.2003 
104. PETERS, O.A.; SCHÖNENBERGER, K.; LAIB, A. Effects of foru Ni$\mathrm{Ti}$, preparation techniques on root canal geometry assessed by micro computed tomography, Int Endod J, London, v.34, n.3, p.221-230, April. 2001.

105. PINTO, S.A.H. Avaliação, através da microscopia eletrônica de varredura, da limpeza de canais radiculares instrumentados pela técnica manual, ultra-sônica ou combinação de ambas, coadjuvadas por alguns agentes irrigadores. Bauru, 1987. 140p. Dissertação (Mestrado em Endodontia)-Faculdade de Odontologia de Bauru, Universidade de São Paulo.

106. PRATI, C.; FOSCHI, F.; NUCCI, C.; MONTEBUGNOLI, L.; MARCHIONNI, S. Appearance of the root canal walls after preparation with $\mathrm{NiTi}$ rotary instruments: a comparative SEM investigation. Clin Oral Invest, v. 8, n. 2, p.102-110, Jun.2004.

107. PRATI, C.; SElEGHINI, M.; FERRIERI, P.; MONGIORGI, R. Scanning electron microscopic evaluation of endodontic procedures on dentin morphology of human teeth. $\mathbf{J}$ Endodon, Baltimore, v. 20 n. 4, p.174-179, Apr.1994.

108. PROKOPOWITSCH, I. Análise "in vitro" da permeabilidade dentinária radicular do terço apical, tendo como fonte de variação a substância química auxiliar da instrumentação (contribuição para o estudo). São Paulo, $1888.65 p$. Dissertação (Mestrado em Endodontia)-Faculdade de Odontologia de São Paulo, Universidade de São Paulo.

109. RHODES, J.S.; PITT FORD, T.R.; LYNCH, J.A.; LIEPINS, P.J.; CURTIS, R.V. A comparison of two nickel-titanium instrumentation techniques in teeth using microcomputed tomography. Int Endod J, London, v.33, n.3, p.279-285, May. 2000.

110. RINGEL, A.M.; PATTERSON, S.S.; NEWTON, C.W.; MILLER, C.H.; MULHERN, J.M. In vivo evaluation of chlorhexidine gluconate 
solution and sodium hypochlorite solution as root canal irrigants. J Endodon, Baltimore, v.8, n.5, p.200-204, May. 1982.

111. RÖDIG, T.; HÜLSMANN, M.; MÜHGE, H.; SCHÄFER, F. Quality of preparation of oval distal root canals in mandibular molars using nickel-titanium instruments. Int Endod J, London, v.35, n.11, p.919-928, Nov. 2002.

112. ROLLISON, S.; BARNETT, F.; STEVENS, R.H. Efficacy of bacterial removal from instrumented root canals in vitro related to instrumentation technique and size. Oral Surg Oral Med Oral Pathol Oral Radiol Endod, St. Louis v.94, n.3, p.366-371, Sep. 2002.

113. ROTA, E.L. Avaliação in vitro da limpeza das paredes dos canais radiculares através da microscopia eletrônica de varredura, quando da utilização de instrumentação manual e rotatória variando-se as substâncias químicas auxiliares. São Paulo, 2003, 136p. Tese (Doutorado em Endodontia) Faculdade de Odontologia de São Paulo, Universidade de São Paulo.

114. RUDDLE, C. Cleaning and shaping the root canal system. In: COHEN, S.; BURNS, R.C. Pathways of the pulp, $8^{\text {th }}$.edn. St. Louis, MO:Mosby, 2002. p.231-291.

115. SANTOS, K.S.A.; SANTOS, R.A. Avaliação da perda de massa dentinária utilizando a lima $\mathrm{K}^{3}$. RGO, Porto Alegre, v.51, n.3, p.183-186, jul/ago/set. 2003.

116. SCELZA, M.F.Z.; ANTONIAZZI, J.H.; SCELZA, P. Efficacy of final irrigation - A scanning electron microscopic evaluation. J Endondon, Baltimore, v.26, n.6, p.355-358, June. 2000.

117. SCHÄFER, E.; FLOREK, H. Efficiency of rotary nickel-titanium $\mathrm{K}^{3}$ instruments compared with stainless steel hand K-Flexofile. Part 1. Shaping ability in simulated curved canals. Int Endod J, London, v.36, n. 3, p.199-207, March. 2003.

118. SCHÄFER, E.; LOHMAN, D. Efficiency of rotary nickel-titanium FlexMaster instruments compared with stainless steel hand $\mathrm{K}$ - 
Flexofile. Part 1. Shaping ability in simulated curved canals. Int Endod J, London, v.35, n. 6, p.505-513, June. 2002.

119. SCHÄFER, E.; VLASSIS, M. Comparative investigation of two rotary nickel-titanium instruments: ProTaper versus RaCe. Part 1. Shaping ability in simulated curved canals. Int Endod J, London, v.37, n. 4, p.229-238, Apr. 2004.

120. SCHÄFER, E.; VLASSIS, M. Comparative investigation of two rotary nickel-titanium instruments: ProTaper versus RaCe. Part 2. Cleaning effectiveness and shaping ability in severely curved root canals of extracted teeth. Int Endod J, v.37, n. 4, p.239-248, Apr. 2004.

121. SCHEREIER, E. The treatment of infected roots-canals with Kalium and Natrium. Dental Cosmos, Philadelphia, v.35, n.9, p.863-869, Sept. 1893.

122. SCHRADER, C.; ACKERMANN, M.; BARBAKOW, F. Step by step description of a rotatory root canal preparation technique. Int Endod J, London, v. 32, n. 4, p. 312-320, Apr.1999.

123. SCHILDER, $H$. Cleaning and shaping the root canal. Dent Clin $\mathbf{N}$ Amer, Philadelphia, v. 18, n.2, p.269-296, Apr.1974.

124. SENIA, E.S.; MARSHALL, F.J.; ROSEN, S. The solvent action of sodium hypochlorite on pulp extracted teeth. Oral Surg Oral Med Oral Pathol, St. Louis, v. 31, n. 1, p.96-10, Jan.1971.

125. SILVA, F.J.; KOBAYASHI, C.; SUDA, H. Analysis of forces developed during mechanical preparation of extracted teeth using RaCe rotary instruments and ProFiles. Int Endod J, London, v. 38, n.1, p.17-21, Jan. 2005.

126. SIQUEIRA Jr, J.F.; HIZATUGU, R.; GAHYVA, S.M.; FAVIERI, A.; GONÇALVES, F.S.; LOPES, H.P. Análise histológica da limpeza apical de canais radiculares após instrumentação. RBO, Rio de Janeiro, v.60, n.1, p.14-17, jan./fev. 2003.

127. SIQUEIRA, E.L. Dissolução de tecido pulpar bovino por duas composições químicas utilizadas em Endodontia. São Paulo, 
2004, 102p. Tese (Doutorado em Endodontia) Faculdade de

Odontologia de São Paulo, Universidade de São Paulo.

128. SKINNER, L.M.; PHILLIPS, R.W. Skinner - Materiais Dentários, $9^{a}$ ed. Guanabara Koogan - RJ, p. 32-33, 1993.

129. SLUTZKY-GOLDBERG, I.; LIBERMAN, R.; HELING, I. The effect of instrumentation with two different file types, each with 2,5\% $\mathrm{NaOCl}$ irrigation on the microhardness of root dentin. $\mathbf{J}$ Endodon, Baltimore, v.28, n.4. p.311-312, April. 2002.

130. SOARES, I.J.; GOLDBERG, F. Endodontia: Técnicas e Fundamentos. Porto Alegre: Artes Médicas Sul, 2001.

131. SOUZA, R.E.; Avaliação in vitro da capacidade de limpeza dos quelantes CDTA, EGTA e EDTA no canal radicular. Análise histológica. Ribeirão Preto, 2002, 106p. Dissertação (Mestrado em Endodontia) Faculdade de Odontologia, Universidade de Ribeirão Preto.

132. SOUZA, R.E.; SOUZA, E.A.; SILVA-SOUSA, Y.C.; SOUSA NETO, M. D. Avaliação da remoção de smear layer do canal radicular usando EDTA 17\%, CDTA 1\% e EGTA 1\%. Rev Odonto Ciência, Porto Alegre, v. 18, n. 40, p. 112-116, abril/jun.2003.

133. SOUZA, R.E.; SOUZA, E.A.; VALERA, F.B.; MORAES, I.G. Avaliação da remoção de debris após irrigação com EDTA 17\% e EGTA 1\% associados ao hipoclorito de sódio 1\% - Análise histológica. Rev Odonto Ciência, Porto Alegre, v.20, n. 47, 11-17, jan/março.2005.

134. SPANÓ, J.C.E. Estudo in vitro das propriedades físico-químicas das soluções de hipoclorito de sódio, em diferentes concentrações, antes e após a dissolução de tecido pulpar bovino. Ribeirão Preto, 1999, 96p. Dissertação (Mestrado) Faculdade de Odontologia de Ribeirão Preto, Universidade de São Paulo. 
135. STEWART, G.G. The importance of chemomechanical preparation of the root. Oral Surg Oral Med Oral Pathol, St. Louis, v.8, n.9, p.993-997, Sept. 1955.

136. TAKEDA, F.H.; HARASHIMA,T.; KIMURA,Y.; MATSUMOTO, K. A comparative study of the removal of smear layer by three endodontic irigants and two types of laser. Int Endod J, London,v.32,v.1,p.32-39, Jan.1999.

137. TEIXEIRA, F.B.; FERRAZ, C.C.R.; ZAIA, A.A.; GOMES, B.P.F.A.; SOUZA-FILHO, F.J.; OLIVEIRA, D.P. Remoção de smear layer dos canais radiculares utilizando o irrigante Endoquil. RBO, Rio de Janeiro, v. 58, n.6, p.424-426, nov/dez.2001.

138. TORABINEJAD, M.; HANYSIDES, R.; KHADEMI, A.A.; BAKLAND, L.K. Clinical implication of the smear layer in endodontics: a review. Oral Surg Oral Med Oral Pathol Oral Radiol Endod, St. Louis, v. 94, n. 6, p.658-666, Dec.2002.

139. TREPAGNIER, C.M.; MADDEN, R.M.; LAZZARI, E.P. Quantitative study of sodium hypochlorite as an in vitro endodontic irrigant. J Endodon, Baltimore, v. 3, n. 5, p. 194-196, May.1977.

140. VAUGHAN, M.E.; GARNICK, J.J. The effect of a 0,125\% chlorhexidine rinse on inflammation after periodontal surgery. J Periodontol, Chicago, v.60, n. 12, p.704-708, Dec. 1989.

141. WALIA, H.M.; BRANTLEY, W.A.; GERSTEIN, H. An initial investigation of the bending and torsional properties of Nitinol root canal files. J Endod, Baltimore, v.14, n.7, p.346-351, Jul.1988.

142. WALKER, A. A definite and dependable therapy for pulpless teeth. $\mathbf{J}$ Am Dent Am, Chicago, v.23, n.2, p.1418-1425, Aug. 1936.

143. WALTERS,M.J.; BAUMGARTHER, J.C.; MARSHALL, J.G. Efficacy of irrigation with rotary instrumentation. J Endodon, Baltimore, v.28, n.12, p.837-839,Dec.2002.

144. WALTON, R.E. Histologic evaluation of differents methods of enlarging the pulp canal space. J Endodon, Baltimore, v.2, n. 10, p.304-311, Oct.1976. 
145. WEIGER, R.; ELAYOUTI, A.; LÖST, C. Efficiency of hand and rotary instruments in shaping oval root canals. J Endodon, Baltimore, v.28,n.8, p.580-583,Aug.2002.

146. WEINE, F.S. Endodontic therapy $2^{\text {nd }}$ ed. Saint Louis, Mosby, 1982. p. 201-210.

147. WEINE, F.S.; HEALEY, H.J.; GERSTEIN, H.; EVANSON, J. Precurved files and incremental instrumentation for root canal enlargement. J Can Dent Assoc, v. 36, n. 4, p. 155-157, Apr.1970.

148. WEINE, F.S.; KELLY, R.F.; LIO, P.J. The effect of preparation procedures on original canal shape and on apical foramen shape. J Endodon, Baltimore, v.1, n. 8, p. 255-262, Aug.1975.

149. WEST, J.D.; ROANE, J.B.; GOERIG, A.C. Cleaning and shaping the root canal system. In: COHEN, S.; BURNS, R.C. Pathways of the pulps. $6^{\text {th }}$. St Louis, USA: Mosby Year Book, 1994. 179-218.

150. WILLIAMS, S.; GOLDMAN, M. Penetrability of the smear layer by a strain of Proteus vulgaris. J Endodon, Baltimore, v.11, n.9, p.385-387, Sep. 1985.

151. WRIGHT, H.N. FENSKE, E.L. Factors involved in variability in hardness of tooth structures. J Dent Res, St Louis, v. 17, n. 1, p. 297, March.1938.

152. YAMADA, R.S.; ARMAS, A.; GOLDMAN, M.; LIN. P.S. A scanning electron microscopic comparison of high volume final flush with several irrigating solutions: Part 3. J Endodon, Baltimore, v. 9, n. 4, p. 137-142, April. 1983.

153. YAMASHITA, J.C.; TANOMARU FILHO, M.; LEONARDO, M.R.; ROSSI, M.A.; SILVA, L.A.B. Scanning electron microscopic study of the cleaning ability of chlorhexidine as a root-canal irrigant. Int Endod J, London, v. 36, n. 6, p. 391-394, Jun.2003.

154. YARED, G.M.; DAGHER, F.E.; MACHTOU, P.; KULKARNI, G.K. Influence of rotational speed, torque and operator proficiency on 
failure of Greater Taper files. Int Endod J, London, v.35, n.1, p.712, Jan.2002.

155. ZELADA, G.; VARELA, P.; MARTíN, B.; BAHÍLIO, J.G.; MAGÁN, F. AHN, S. The effect of rotational speed and the curvature of root canals on the breakage of rotary endodontic instruments. J Endodon, Baltimore, v.28, n.7, p.540-542, July. 2002. 
Abstract 
This study compared the efficiency of rotary and manual-mechanical instrumentation with variations in the auxiliary chemical in the middle and apical thirds as to the presence of smear layer. The study was conducted on 95 human teeth. As a control 15 teeth were divided into 3 groups. The other teeth were according to the study conditions: manual-mechanical instrumentation; rotary instrumentation with the ProTaper; RaCe and the $\mathrm{K}^{3}$. Each of these groups was employed: $0.12 \%$ chlorhexidine gluconate and $1 \%$ sodium hypochlorite. Each tooth was analyzed by MEV. Analysis of the results revealed no difference between the middle and apical thirds, regardless of the techniques or solutions. When the sodium hypochlorite solution was used, concerning the middle third the $\mathrm{K}^{3}$ exhibited better results. The apical third and global performance did not present statistical difference. With regard to the chlorhexidine, global analysis of the middle and apical third did not reveal statistical difference. Assessment of the instrumentation techniques, regardless of the irrigants and thirds, as to the presence of smear layer, did not exhibit statistical difference. Chlorhexidine was statistically better than sodium hypochlorite at the middle third, whereas at the apical third both solutions were statistically similar. 
Apêndice 


\section{Apêndice 1. Protocolo enviado ao Comitê de Ética em Pesquisa}

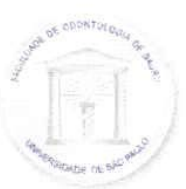

Universidade de São Paulo

Faculdade de Odontologia de Bauru

A1. Dr. Octávio Pinheiro Brisolla, 9-75 - Bauru-SP - CEP 17012-101 - C.P. 73

PABX (0XX14)3235-8000-FAX (0XX14)3223-4679

Comilê de Éfica em Pesquisa

\section{PROTOCOLO DE RECEBIMENTO}

Proc. $N^{\circ} 41 / 2004$

Titulo do Projeto: $\begin{aligned} & \text { Avaliação da limpeza dentinária radicular após preparo de } \\ & \text { canais radiculares com dois sistemas rotatórios associados a }\end{aligned}$ três diferentes soluções auxiliares

Autor(es):

Rogério Emílio de Souza

Orientador(a) :

Prof. Dr. Norberti Bernardineli

Co-orientador(a)

Data de entrega :

23 de março de 2004

*Reunião do CEP : $\quad 28$ de abril de 2004

oncuibila Maristela P. F. Fabrini

Secretária do Comitê de Ética em Pesquisa em Seres Humanos, da FOB/USP

\footnotetext{
* As reuniões do CEP serão realizadas na última quarta-feira do mês. Para serem analisados, os trabalhos deverão ser entregues 15 (quinze) dias antes da reunião, para permitir ao relator analisar e emitir seu parecer.
} 


\title{
Apêndice 2. Resposta do protocolo enviado ao Comitê de Ética em Pesquisa
}

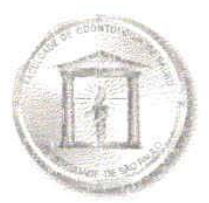

Processo $n^{\circ} 41 / 2004$

\author{
Universidade de São Paulo \\ Faculdade de Odontologia de Bauru \\ Al. Dr. Octávio Pinheiro Brisolla. 9-75 - Bauru-SP - CEP 17012-901 - C.P. 73 \\ PABX (0XX14)3235-8000 - FAX (0XX14)3223-4679 \\ Comitê de Éfica em Pesquisa
}

Bauru, 10 de maio de 2004

Senhor Professor

O projeto de pesquisa encaminhado a este Comitê de Ética em Pesquisa em Seres Humanos, denominado "Avaliaç̃o da limpeza dentinária radicular após preparo de canais radiculares com dois sistemas rotatórios associados a três diferentes soluções auxiliares", de autoria de Rogério Emilio de Souza, que será desenvolvido sob sua orientação, foi enviado ao relator para avaliação.

Na reunião de 28 de abril de 2004 o parecer do relator, aprovando o projeto, foi aceito pelo Comitê, considerando que não existem infrações éticas pendentes.

Informamos que após o envio do trabalho concluido, este Comitê enviará o parecer final, que será utilizado para publicação do trabalho.

Atenciosamente,

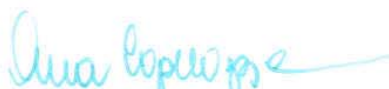

Prof' Dr't Ana Lúcia Alvares Capelozza

Coordenadora

$11 \mathrm{~m}^{\circ} \mathrm{Sr}$. Prof. Dr. Norberti Bernardineli

DD. Docente do Departamento de Dentistica, Endodontia e Materiais Dentários 
Apêndice 3. Autorização de mudança de título do projeto de pesquisa

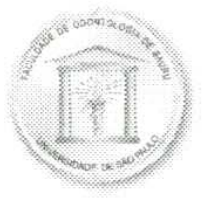

\section{Universidade de São Paulo \\ Faculdade de Odontologia de Bauru}

Al. Dr Octávio Pinheiro Brisolla, 9-75 - Bauru-SP - CEP 17012-901 - C.P. 73

PABX (0XX14)3235-8000 - FAX (0XX14)3223-4679

Comitê de Ética em Pesquisa (3235-8356)

Of. $n^{\circ}$ CEP/20 2005/FOB

Of.CEP-Proc. $N^{\circ} 41 / 2004$

Bauru, 20 de abril de 2005 .

Senhor Professor,

Conforme sua solicitação referente a modificação de título do trabalho de pesquisa aprovado em 28 de abril de 2004, intitulado "Avaliação da limpeza dentinária radicular após preparo de canais radiculares com dois sistemas rotatórios associados a rês diferentes soluçóes auxiliares" de autoria do CD. Rogério Emílio de Souza, desenvolvido sob orientação, informamos que após análise autorizamos a alteração para o título "Avaliação da eficácia dos métodos de instrumentação e de substâncias químicas nas paredes de canais radiculares - estudo em microscopia eletrônica de varredura", considerando não ter modificado a metodologia proposta.

Lembramos que após o envio do trabalho concluído, este Comitê enviará o parecer final, que será utilizado para a publicação do trabalho.

Atenciosamente,

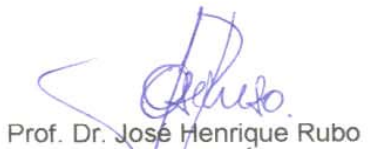

Coordenador do Comitê de Ética em Pesquisa

$\| m^{\circ}$ Sr. Prof. Dr. Norberti Bernardineli

DD. Docente do Departamento de Dentistica, Endodontia e Materiais Dentários 